\title{
Design of Geothermal District Heating and Cooling System for the West Virginia University
}

\author{
OLUWASOGO BOLAJI ALONGE \\ West Virginia University, obalonge@mix.wvu.edu
}

Follow this and additional works at: https://researchrepository.wvu.edu/etd

Part of the Other Chemical Engineering Commons

\section{Recommended Citation}

ALONGE, OLUWASOGO BOLAJI, "Design of Geothermal District Heating and Cooling System for the West Virginia University" (2019). Graduate Theses, Dissertations, and Problem Reports. 7397.

https://researchrepository.wvu.edu/etd/7397

This Thesis is protected by copyright and/or related rights. It has been brought to you by the The Research Repository @ WVU with permission from the rights-holder(s). You are free to use this Thesis in any way that is permitted by the copyright and related rights legislation that applies to your use. For other uses you must obtain permission from the rights-holder(s) directly, unless additional rights are indicated by a Creative Commons license in the record and/ or on the work itself. This Thesis has been accepted for inclusion in WVU Graduate Theses, Dissertations, and Problem Reports collection by an authorized administrator of The Research Repository @ WVU. For more information, please contact researchrepository@mail.wvu.edu. 


\title{
Design of Geothermal District Heating and Cooling System for the West Virginia University
}

\author{
Oluwasogo Bolaji Alonge
}

Thesis submitted

to the Benjamin M. Statler College of Engineering and Mineral Resources at West Virginia University

in partial fulfillment of the requirements for the degree of

\author{
Master of Science in \\ Chemical Engineering \\ Nagasree Garapati, Ph.D., P.E., Chair \\ Fernando Lima, Ph.D. \\ Debangsu Bhattacharyya, Ph.D.
}

Department of Chemical Engineering

Morgantown, West Virginia

2019

Keywords: Levelized cost of heat, Geothermal, District heating and cooling system, Steam-based system, GEOPHIRES, Aspen simulators, HYSYS, Surface plant, West Virginia University.

Copyright 2019 Oluwasogo Bolaji Alonge 


\section{Abstract \\ Design of Geothermal District Heating and Cooling System for the West Virginia University \\ Oluwasogo Bolaji Alonge}

Recent Appalachian Basin Geothermal Play Fairway Analysis estimated elevated heat flows in north-central West Virginia. This region provides an optimal and unique combination of elevated temperatures and flow necessary for geothermal development along with year-round surface demand for heating and cooling on the campus. Therefore, West Virginia University's (WVU's) Morgantown campus has been identified as a prime location in the eastern United States for the development of a geothermal direct-use heating and cooling application.

The objective of this study was to perform a feasibility analysis for the development of a geothermal district heating and cooling (GDHC) system for WVU campus in Morgantown, WV, to replace the current coal-fired steam heating and cooling system. A hybrid GDHC system is proposed to replace the existing system based on the data collected the project period from the existing district heating and cooling (DHC) facilities and Aspen simulations were conducted to analyze two scenarios for the design of a heating and cooling system at WVU's Morgantown campus and calculate surface plant capital costs. Scenario 1 would supply superheated steam to the entire campus and Scenario 2 would deliver saturated steam to the Health Sciences and Evansdale campuses. The overall economics of the geothermal system was performed using modified GEOPHIRES. For the two scenarios considered, geothermal contribution to the heating and cooling on WVU campus is around 2.30 to $2.43 \%$ and 4.05 to $4.39 \%$ for hybrid geothermal system and improved hybrid geothermal system with heat pump, respectively.

Currently, WVU pays \$15/MMBTU for steam supplied by the Morgantown Energy Associates (MEA) coal-fired power plant. Utilizing the existing pipeline distribution system, this study results yielded the levelized cost of heat $(\mathrm{LCOH})$ for the two scenario designs in the ranges of 7.55 to 10.90 \$/MMBTU for vertical well configuration and 7.77 to 11.60 \$/MMBTU for horizontal well configuration which is well below the current price for steam supplied by MEA. To address uncertainty related to the distribution systems, LCOH was calculated in GEOPHIRES for a case where existing pipelines are to be purchased from MEA and for an instance where a new set of pipelines are to be installed by WVU. Purchasing or installing new pipeline distribution facilities if existing pipeline networks are not donated by MEA resulted in $\mathrm{LCOH}$ in the range of 8.50 to 14.08 \$/MMBTU which shows that $\mathrm{LCOH}$ values increase with additional capital cost for the distribution pipelines. However, the range of $\mathrm{LCOH}$ values calculated for the natural gas fired boiler (NGFB) system without geothermal (5.65 to 7.46 \$/MMBTU) is comparably lower than the range of values obtained for the proposed hybrid GDHC system. Nevertheless, the proposed hybrid GDHC system for WVU can provide clean energy to replace the existing MEA coal-fired, steambased system; hence, providing an alternative to offset the impacts from fossil fuels consumption. Further, analysis of the future price of fuel showed that proposed hybrid system will be more economical compared to NGFB at a natural price of about $\$ 15.00 / 1000 \mathrm{ft}^{3}$. 


\section{Dedicated to the Glory of Almighty God}

"the Holy One of Israel" 


\section{Acknowledgements}

I would like to offer a thankful note to several individuals and organizations that have supported me in the course of my thesis.

First and foremost, I would like to express my deepest appreciation to my advisor, Dr. Nagasree Garapati, who has provided many ingenious suggestions from the start of the project to the end. Without her numerous suggestions and remarkable contributions, the goal of this project would not have been realized. I have greatly benefitted from her guidance and illustrious suggestions and I considered it a great privilege for providing me the opportunity to work on the project.

I would like to thank my committee members, Dr. Lima and Dr. Bhattacharyya for their inputs and insightful recommendations in the course of this project. I am extremely grateful for their help, feedback and guidance at different phases of the project. This thesis completion would not have been possible without the support and nurturing from my committee from time to time.

I would also like to extend my gratitude to Dr. Richard Turton for creating time out of his busy schedule to review the thesis document and for ensuring the successful completion of this project. I am deeply indebted to your valuable advice in the course of writing this thesis.

I am grateful to Dr. Koenraad Beckers for the help and suggestions in editing the GEOPHIRES codes for a hybrid system. I would also like to express my gratitude to U.S. Department of Energy for providing the platform to work on this project through the project funding. I would also like to appreciate the WVU Facilities Management for providing to some of the data and drawings, and for the warmth reception at various meetings. I am also thankful to the following colleagues: Selorme Agbleze, Brent Bishop, Shuyun Li, Paul Akula and Dr. Oluwaotosin Oginni for the wonderful moments we have shared together.

Finally, I would like to acknowledge the support of my parents and family for providing me with unflinching support and unrelenting inspiration throughout the duration of this thesis. This accomplishment would not have been possible without their encouragement. 


\section{Table of Contents}

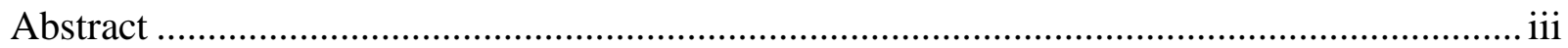

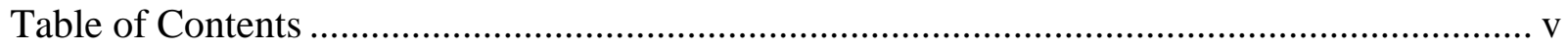

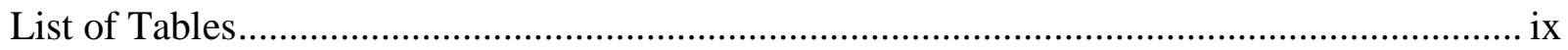

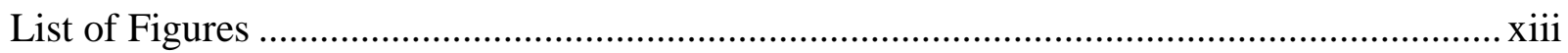

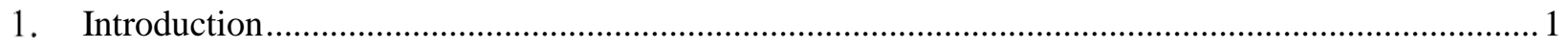

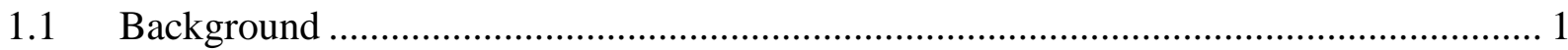

1.2 Geothermal Energy as a Renewable Energy Source ............................................... 3

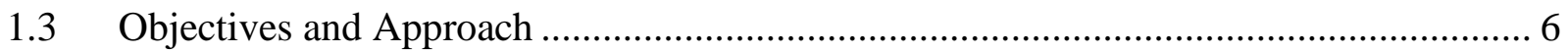

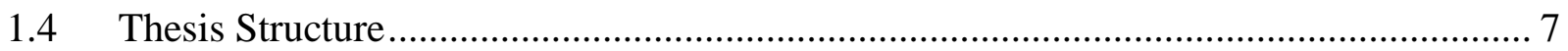

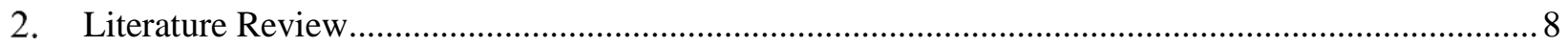

2.1 Development of Geothermal District Heating and cooling (GDHC) System in US....... 8

2.2 Surface Plant Development .......................................................................... 9

2.3 Overview of district heating and cooling (DHC) system at WVU .......................... 10

2.3.1 Existing Heating and Cooling System at WVU ....................................................... 10

2.3.2 Proposed Heating and Cooling System at WVU ........................................................... 10

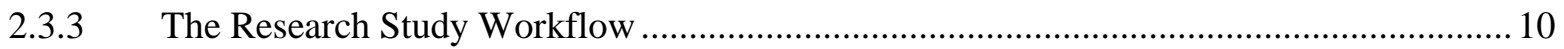

3. Characterization of Existing Infrastructure and Evaluation of Existing Campus District Heating (DH)

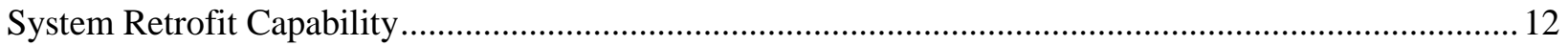

3.1 Objective 1: Characterization of Existing Infrastructure ........................................ 12

3.2 Objective 1: Results and Discussion ................................................................. 12

3.3 Objective 2: Evaluate Existing Campus District Heating (DH) System Retrofit

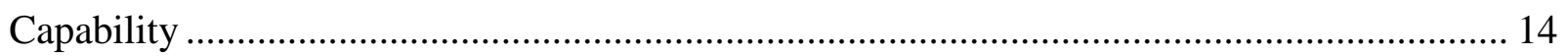

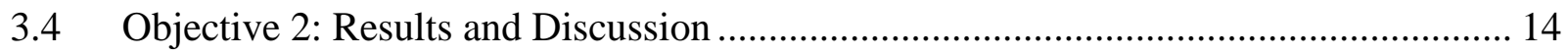

4. Objective 3: Design a Surface Plant and Pipeline Distribution Using Aspen Simulators .................. 15

4.1 Proposed Hybrid Geothermal-Natural Gas System Design ....................................... 15

4.2 Geothermal Heat Exchanger Unit ..................................................................... 19 


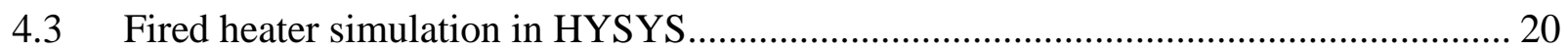

4.4 Distribution Piping System ………………………............................................... 24

4.4.1 The major assumptions and conditions used in distribution pipeline simulation for the

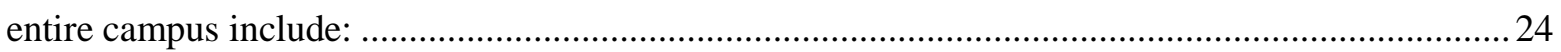

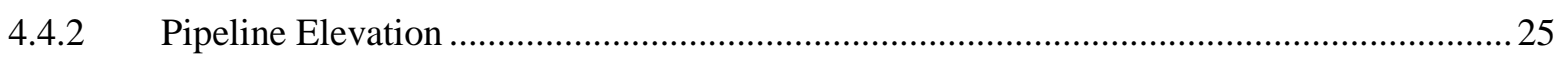

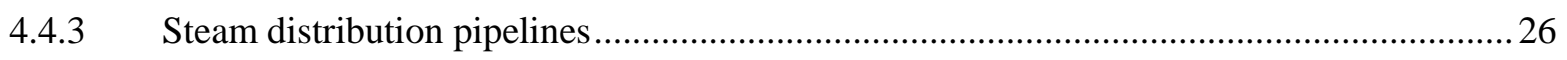

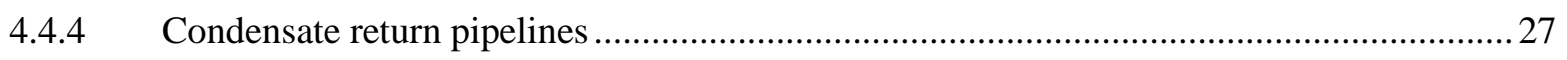

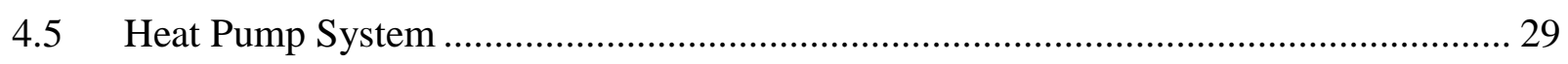

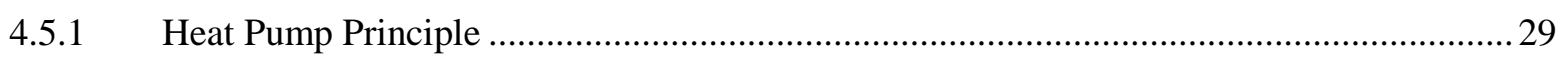

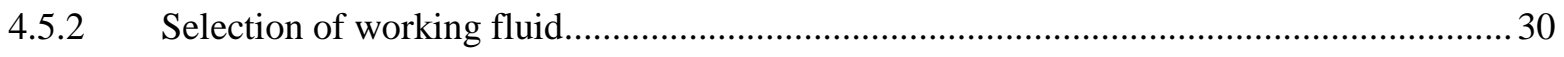

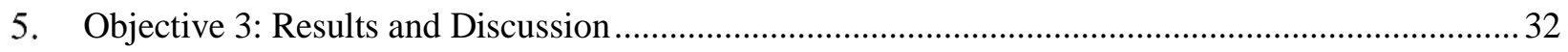

5.1 Geothermal Heat Exchanger Unit Results and Discussion ..................................... 32

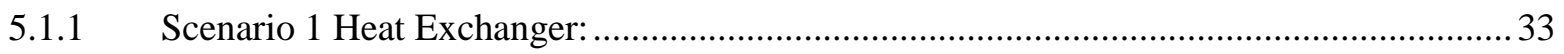

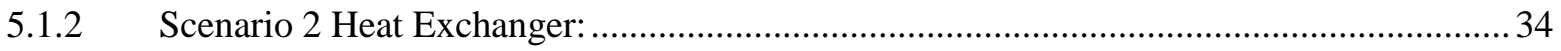

5.2 Geothermal Contribution to the Heating and Cooling System at WVU Results and

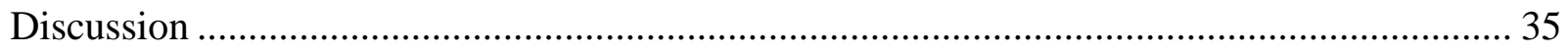

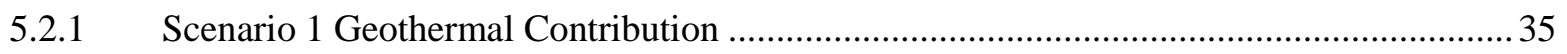

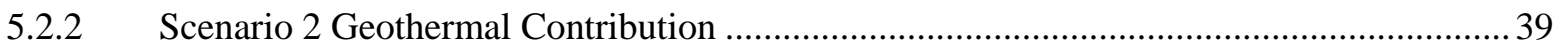

5.3 Boiler Unit: Fired Heater Results and Discussion ............................................. 42

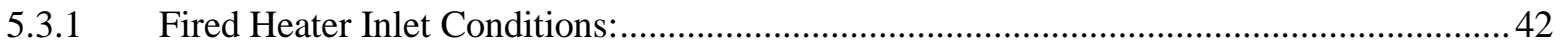

5.4 Ammonia $\left(\mathrm{NH}_{3}\right)$ Heat Pump System ........................................................... 46

5.5 Vendors Quote for Heat Pump and Boiler ........................................................ 49

5.5.1 Boiler Vendor's Quote from Johnston Boiler Company (JBC) :.....................................49

5.5.2 Heat Pump Vendor's Quote from Mayekawa Company: ................................................50

5.6 HYSYS Pipeline Distribution System Simulations Results and Discussion ................ 51

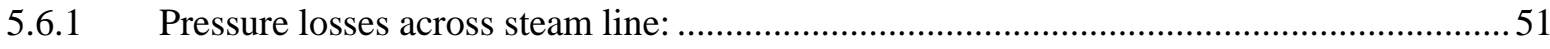

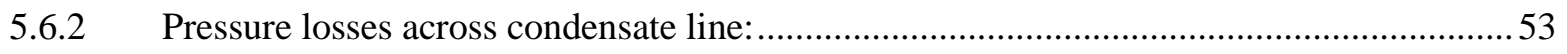


5.7 Aspen ACCE Pipeline Cost Results and Discussion ........................................... 54

5.7.1 Scenario 1 Pipeline Cost from ACCE: .................................................................... 54

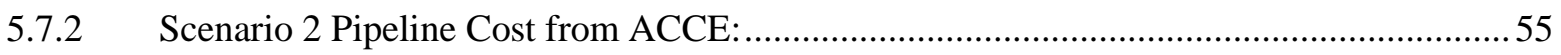

5.8 Aspen ACCE Results for Condensate and Hot Water Pump Costs ........................... 58

5.8.1 Scenario 1 Condensate and Hot Water Pump Costs ......................................................58

5.8.2 Scenario 2 Condensate and Hot Water Pumps Costs ........................................................59

5.9 Aspen ACCE results for Condensate Receiver Tank Cost ..................................... 60

5.10 Surface Plant Equipment Utility and Miscellaneous Costs.................................... 60

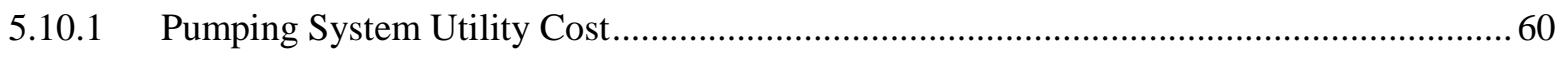

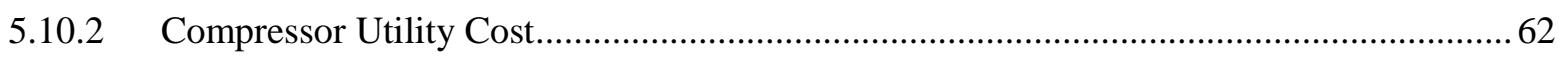

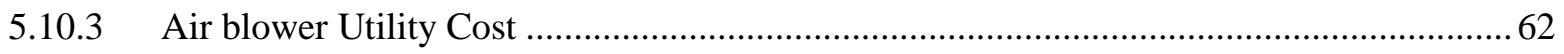

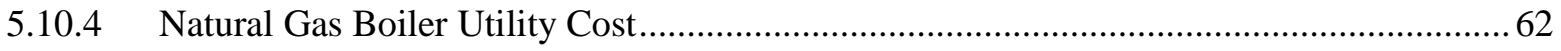

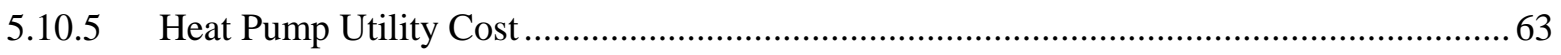

6. Objective 4: Perform an Economic Analysis to Estimate the Levelized Cost of Heat (LCOH) Using

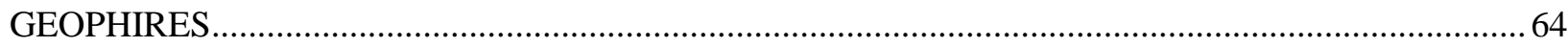

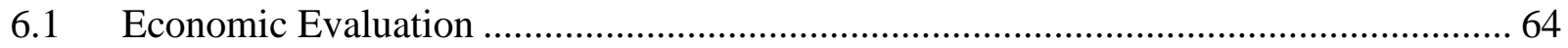

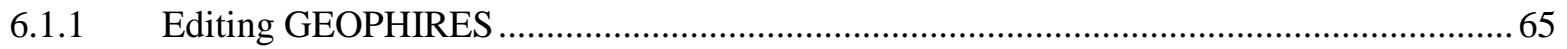

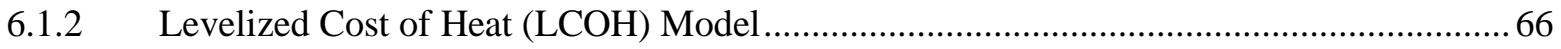

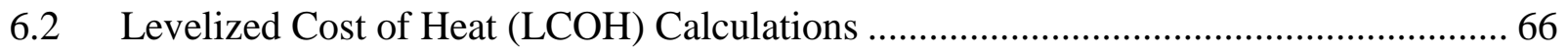

6.3 Total Surface Plant and Capital Cost for Scenario 1 and Scenario 2..........................6 67

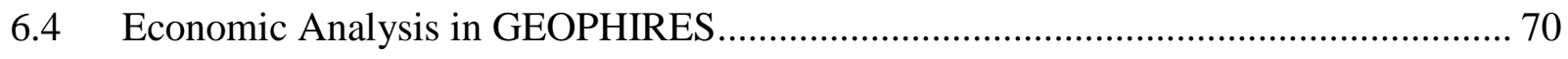

6.4.1 Economic Analysis of Scenario 1 and Scenario 2 with Existing MEA Distribution Pipelines 70

6.4.2 Economic Analysis of Scenario 1 and Scenario 2 with Purchase of Distribution Pipelines 76

Fuel Price Analysis for Case 1A ….................................................................... 78

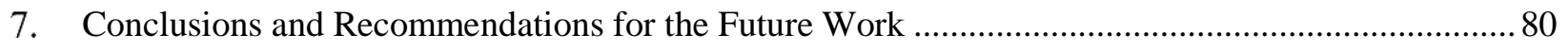




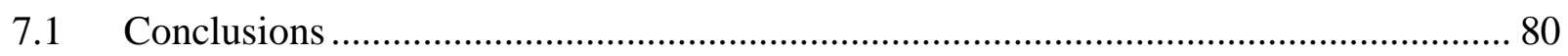

7.2 Recommendations for the Future Work ......................................................... 83 


\section{List of Tables}

Table 4.1: Air and fuel inlet conditions for fired heater simulation in HYSYS ....................... 23

Table 4.2: The elevation changes used in pipeline simulations in HYSYS............................. 25

Table 5.1: The results of HYSYS simulation of geothermal plate heat exchanger (PHE).......... 32 Table 5.2: Results of rigorous design of plate heat exchanger (PHE) in EDR for Scenario 1. Error! Bookmark not defined.

Table 5.3: Results of rigorous design of plate heat exchanger (PHE) in EDR for Scenario 2. .... 34 Table 5.4: Results for Case 1A simulated in HYSYS for geothermal contribution to a hybrid geothermal system without heat pump (\%GEO) to produce superheated steam at 18.25 bar and $260^{\circ} \mathrm{C}$ using geothermal fluid flow rate of $15.2 \mathrm{~kg} / \mathrm{s}$ and varying monthly steam flow rate........ 36 Table 5.5: Results for Case 1A simulated in HYSYS for geothermal contribution to the improved hybrid geothermal system using heat pump $\left(\% G E O_{H P}\right)$ to produce superheated steam at 18.25 bar and $260^{\circ} \mathrm{C}$ using geothermal fluid flow rate of $15.2 \mathrm{~kg} / \mathrm{s}$ and varying monthly steam flow rate. 37 Table 5.6: Results for Case 1B simulated in HYSYS for geothermal contribution to a hybrid geothermal system without heat pump (\%GEO) to produce superheated steam at 14.25 bar and $200^{\circ} \mathrm{C}$ for Med-Center, Towers, Evansdale, and Downtown meter points, and the compressor producing superheated steam at 18.25 bar and $260^{\circ} \mathrm{C}$ for Life Sciences meter point using

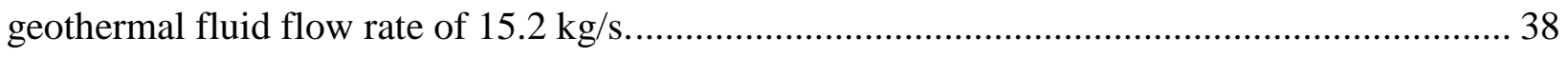
Table 5.7: Results for Case 1B simulated in HYSYS for geothermal contribution to the improved hybrid geothermal system using heat pump $\left(\% G E O_{H P}\right)$ to produce superheated steam at 14.25 bar and $200^{\circ} \mathrm{C}$ for Med-Center, Towers, Evansdale, and Downtown meter points, and the compressor producing superheated steam at 18.25 bar and $260^{\circ} \mathrm{C}$ for Life Sciences meter point using

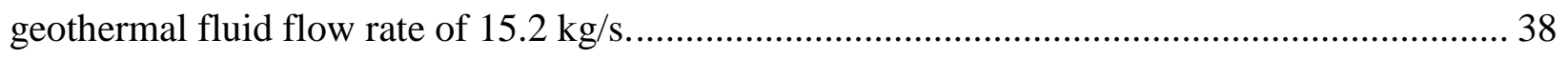
Table 5.8: Results for Case 2A simulated in HYSYS for geothermal contribution to a hybrid geothermal system without heat pump (\%GEO) to produce superheated steam at 12.5 bar using geothermal fluid flow rate of $10.2 \mathrm{~kg} / \mathrm{s}$. 39

Table 5.9: Results for Case 2A simulated in HYSYS for geothermal contribution to the improved hybrid geothermal system using heat pump $\left(\% G E O_{H P}\right)$ to produce superheated steam at 12.5 bar using geothermal fluid flow rate of $10.2 \mathrm{~kg} / \mathrm{s}$.

Table 5.10: Results for Case 2B for geothermal contribution to a hybrid geothermal system without heat pump (\%GEO) with two boilers: one producing saturated steam at 12.5 bar for Evansdale and 
Medical Center meter points, and the second boiler producing low pressure steam at 2.75 bar for Towers using geothermal fluid flow rate of $10.2 \mathrm{~kg} / \mathrm{s}$ 41

Table 5.11: Results for Case 2B for geothermal contribution to the improved hybrid geothermal system using heat pump ( $\% G E O_{H P}$ ) with two boilers: one producing saturated steam at 12.5 bar for Evansdale and Med-Center meter points, and the second boiler producing low pressure steam at 2.75 bar for Towers using geothermal fluid flow rate of $10.2 \mathrm{~kg} / \mathrm{s}$.

Table 5.12: The data obtained from HYSYS simulation of natural gas fuel preheater for Scenario 1 . 42

Table 5.13: The data obtained from HYSYS simulation of natural gas fuel preheater for Scenario 2. 43

Table 5.15: Inlet hot water, flue gas and high pressure steam outlet conditions for the combustion of natural gas simulated in HYSYS fired heater for Case 1A and Case 1B obtained at a fixed boiler efficiency of $\eta=85 \%$, a fixed boiler hot water inlet temperature of $90^{\circ} \mathrm{C}$ for a given natural gas flow rate. 43 Table 5.17: Inlet hot water, flue gas and high pressure steam outlet conditions for the combustion of natural gas simulated in HYSYS fired heater for Case 2A and Case 2B obtained at a fixed boiler efficiency of $\eta=85 \%$, a fixed boiler hot water inlet temperature of $90^{\circ} \mathrm{C}$ for a given natural gas flow rate. 45

Table 5.19: Results of rigorous design in EDR and Aspen ACCE estimation for the natural gas preheater (shell and tube heat exchanger) for Scenario 1 and Scenario 2 . .............................. 46 Table 5.20: Results of the coefficient of performance for Scenario 1 and Scenario 2............... 48 Table 5.21: Vendor's quote obtained from Johnston Boiler Company (JBC) for Scenario 1 and Scenario 2 boilers simulated in HYSYS.

Table 5.23: High temperature heat pump package performance obtained from Mayekawa Company.

Table 5.24: Mayekawa Company ammonia heat pump quote parameters compared to Aspen Scenario 1 and Scenario 2 heat pump parameters simulated in HYSYS. Red section represents the heat pump system conditions obtained from HYSYS simulation. 51 Table 5.25: Pressure drop across the steam pipelines for Scenario 2 (Case 1A and Case 1B). Red section represents new pipelines and black section represents existing MEA pipelines. 52 
Table 5.26: Pressure drop across steam pipelines for Scenario 2 (Case 2A and Case 2B). Red section represents new pipelines and black section represents existing MEA pipelines............ 52 Table 5.27: Pressure drop across condensate pipelines for Scenario 1. Red section represents new pipelines and black section represents existing MEA pipelines. .......................................... 53 Table 5.28: Pressure drop across condensate pipelines for Scenario 2. Red section represents new pipelines and black section represents existing MEA pipelines.

Table 5.29: The result of the pipeline simulated in HYSYS for the steam and condensate pipelines. Red section represents new pipelines and black section represents existing MEA pipelines. ..... 54 Table 5.30: The result of Case 2A pipeline simulated in HYSYS for the steam and condensate pipelines. Red section represents new pipelines and black section represents existing MEA pipelines 56

Table 5.31: The result of Case 2B pipeline simulated in HYSYS for the steam and condensate pipelines. Red section represents new pipelines and black section represents existing MEA

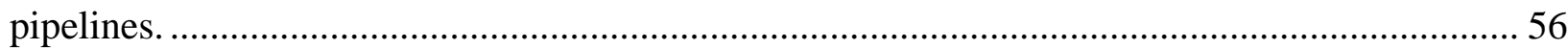

Table 5.32: The result of the pipeline simulated in HYSYS for the natural gas pipelines.......... 57 Table 5.34: Scenario 1 (Case 1A and Case 1B) results of Aspen ACCE pump costs estimated for the hot water and condensate pumps to provide hot water to the boiler unit and transport of condensate to the centralized surface plant for re-use by geothermal heat exchanger................ 58 Table 5.35: Scenario 2 (Case 2A and Case 2B) results of Aspen ACCE pump cost estimate for the hot water and condensate pumps to provide hot water to the boiler unit and transport of condensate to the centralized surface plant for re-use by geothermal heat exchanger. Red section represents the corresponding hot water pump required for the new Tower pipelines. 59 Table 5.36: The result of the cost of the condensate receiver tanks estimated in Aspen ACCE for Scenario 1 and Scenario 2. 60

Table 5.37: The result of the utility cost estimated for pumping system at an electricity rate of $\$ 0.067 / \mathrm{kWh}$ for Scenario 1 . 61

Table 5.38: The result of the utility cost estimated for pumping system at an electricity rate of $\$ 0.067 / \mathrm{kWh}$ for Scenario 2. Red section is for additional pump require for the new Towers steam pipeline. 61

Table 5.39: The result of the utility cost estimated for the compressor at an electricity rate of $\$ 0.067 / \mathrm{kWh}$ 62 
Table 5.40: The result of the utility cost estimated for the air blower at an electricity rate of $\$ 0.067 / \mathrm{kWh}$

Table 5.41: Scenario 1 and Scenario 2 results of the utility cost estimated for natural gas supply at a rate of $\$ 4.12 / 1000 \mathrm{ft}^{3}$

Table 6.2: Aspen ACCE results, vendors quote and utility costs for the surface plant equipment for Scenario 1 which supplies superheated steam to the entire campus and for Scenario 2 which supplies saturated steam to Health Sciences and Evansdale (Towers and Evansdale) campuses. 68 Table 6.3: Natural gas boiler Aspen ACCE results, vendors quote and utility costs for the surface plant equipment for Scenario 1 which supplies superheated steam to the entire campus and for Scenario 2 which supplies saturated steam to Health Sciences and Evansdale (Towers and Evansdale) campuses. 69

Table 6.5: Parameters input into GEOPHIRES for Scenario 1 and Scenario 2 Hybrid GDHC system at WVU.

Table 6.6: Aspen simulators output, surface technical parameters, utility costs, total capital costs and O\&M costs fed into GEOPHIRES to determine LCOH at WVU. 73 Table 6.7: The results of economic analysis for Scenario 1 and Scenario 2 simulated in GEOPHIRES for the vertical well. 74

Table 6.8: The results of economic analysis for Scenario 1 and Scenario 2 simulated in GEOPHIRES for the horizontal well.

Table 6.9: The results of excel LCOH calculation for NGFB using BICYCLE economic model for Scenario 1 and Scenario 2. 78

Table 6.10: The LCOH results of the proposed hybrid GDHC system compared with NGFB system at different natural gas prices for Case 1A. .79 


\section{List of Figures}

Figure 1.1: U.S. energy consumption based on energy source [1] . ..................................... 1

Figure 1.2: Global $\mathrm{CO}_{2}$ atmospheric concentration [2] ................................................ 2

Figure 1.3: Global investment in renewable energy technologies [3] .................................... 3

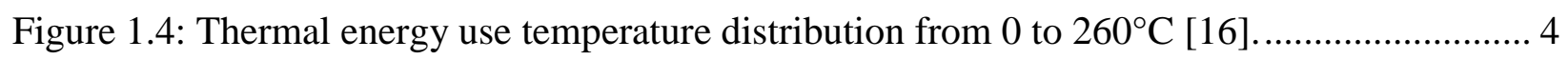

Figure 1.5: The updated heat flow map of the conterminous United States ( [19], the circle

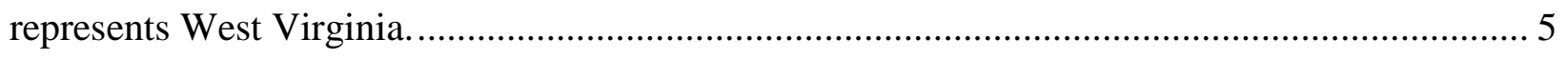

Figure 2.1: The locations of geothermal district heating system in US [27]. ........................... 8

Figure 2.2: A schematic of the workflow for the design and economic analysis of a hybrid GDHC

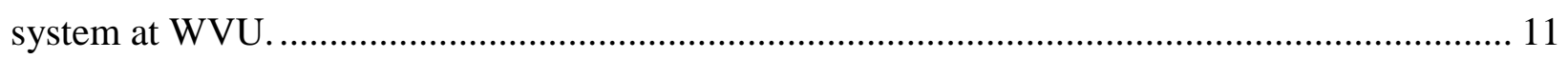

Figure 3.1: WVU steam data for (a) temperature $\left({ }^{\circ} \mathrm{F}\right)(\mathrm{b})$ pressure (psig) (c) flow rate (PPH) for Health Sciences campus (Medical Center meter point) for June 2019................................. 13

Figure 3.2: Annual WVU campus steam consumption data for the current DHC system at WVU

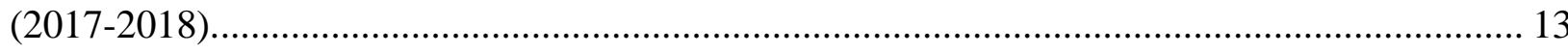

Figure 3.3: One-line drawing of MEA's pipelines with distribution meter points along with linear

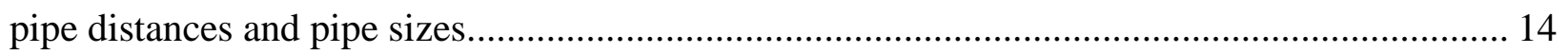

Figure 4.1: Schematic of the proposed hybrid geothermal-natural gas boiler systems for West

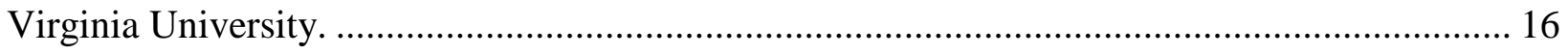

Figure 4.2: Schematic of the proposed hybrid geothermal-natural gas boiler system improvised with heat pump system for West Virginia University. .................................................... 17

Figure 4.3: The aerial view of the proposed geothermal well site location at Health Sciences. .. 18

Figure 4.4: Boiler unit and other combustion components simulated in HYSYS.................... 22

Figure 4.5: The schematic of the steam line simulated for Scenario 1 (Case 1A \& Case 1B) pipeline

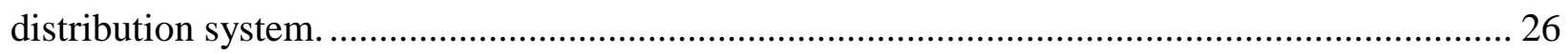

Figure 4.6: The schematic of steam line simulated for Scenario 2 (Case 2A \& Case 2B) pipeline

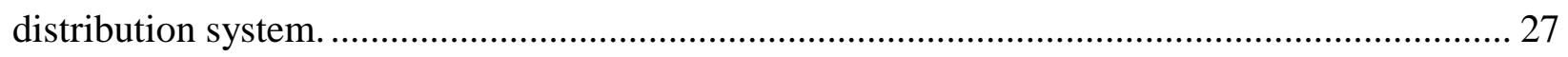

Figure 4.7: The schematic of the condensate line for Scenario 1 (Case 1A \& Case 1B) pipeline

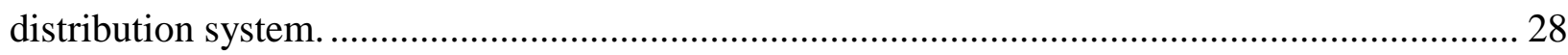

Figure 4.8: The schematic of the condensate line for Scenario 2 (Case 2A \& Case 2B) pipeline

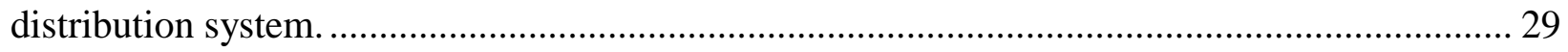

Figure 4.10: A simplified diagram of a heat pump system [57] ........................................ 30 
Figure 5.1: Details of the geometry obtained from rigorous heat exchanger design in EDR for

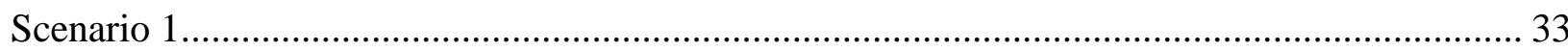

Figure 5.2: Details of the geometry obtained from rigorous heat exchanger design in EDR for

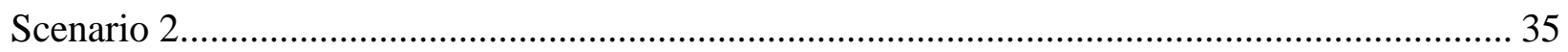

Figure 5.3: The proposed heat pump configuration using ammonia as a working fluid. ............ 47 Figure 5.4: Pressure-enthalpy (p-h) diagram of the ammonia heat pump simulated in HYSYS. The major components for the heat pump simulated are represented by compressor (1-2), condenser

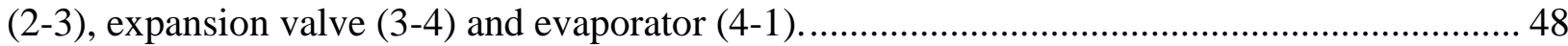

Figure 5.5: Schematic of the proposed steam pipeline distribution from geothermal well site location to the five meters across the entire WVU campus................................................ 51 Figure 6.1: Scenario 1 (Case 1A and Case 1B) and Scenario 2 (Case 2A and Case 2B) LCOH values simulated in GEOPHIRES for NNE well at additional capital costs of \$15M and \$25M.77 Figure 6.2: Scenario 1 (Case 1A and Case 1B) and Scenario 2 (Case 2A and Case 2B) values simulated in GEOPHIRES for default (DF) well at additional capital costs of \$15M and \$25M.77 


\section{Introduction}

\subsection{Background}

Energy production and consumption have been around for centuries; during early civilization, sunlight was used for making fire and wood was burned for cooking and heat. However, since the industrial revolution, large-scale energy production became a global trend with fossil fuels providing most of the energy consumed globally. For example, Figure 1.1 shows that in 2017, U.S. consumed 103.1 EJ (97.7 quadrillion Btu) of primary energy, of which $80 \%$ came from fossil fuels like petroleum, coal, and natural gas [1]. Nuclear energy (9\%) and renewable energy resources (11\%) contributed to the remaining $20 \%$ of the total primary energy consumption.

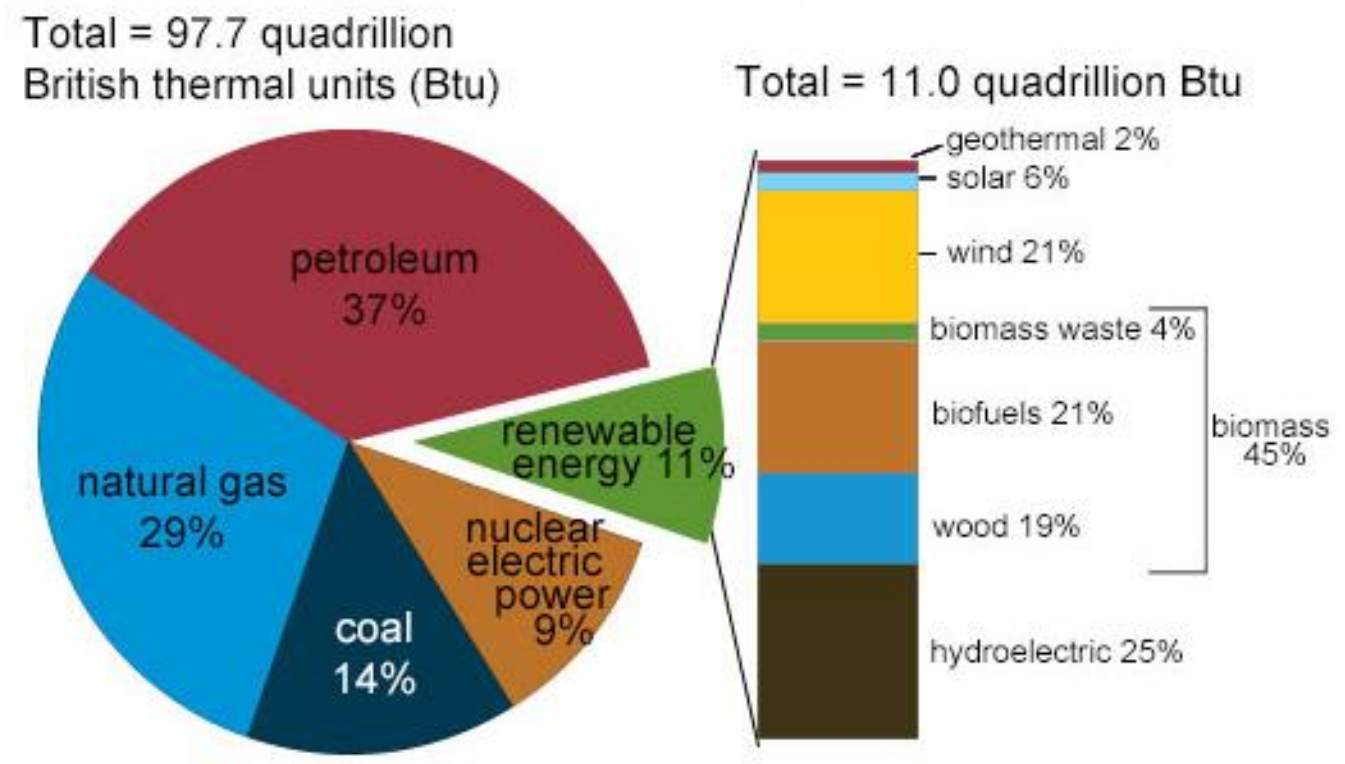

Figure 1.1: U.S. energy consumption based on energy source [1].

However, fossil fuels have important impacts on the environment as production of electricity from these sources can produce carbon dioxide and other greenhouse gases (GHG). Figure 1.2 shows there is a continuous increase in the mean annual concentration of atmospheric carbon dioxide $\left(\mathrm{CO}_{2}\right)$ [2]. This results in increase in world average temperature, extreme weather conditions (melting of polar ice, flooding droughts etc.), and other notable climate changes which have a greater impact on human health, ecological, and physical environments [3]. There is a need to 
balance energy production, energy consumption, and their environmental impact to develop a sustainable energy system; therefore, attention has been shifted towards investing and developing renewable energy.

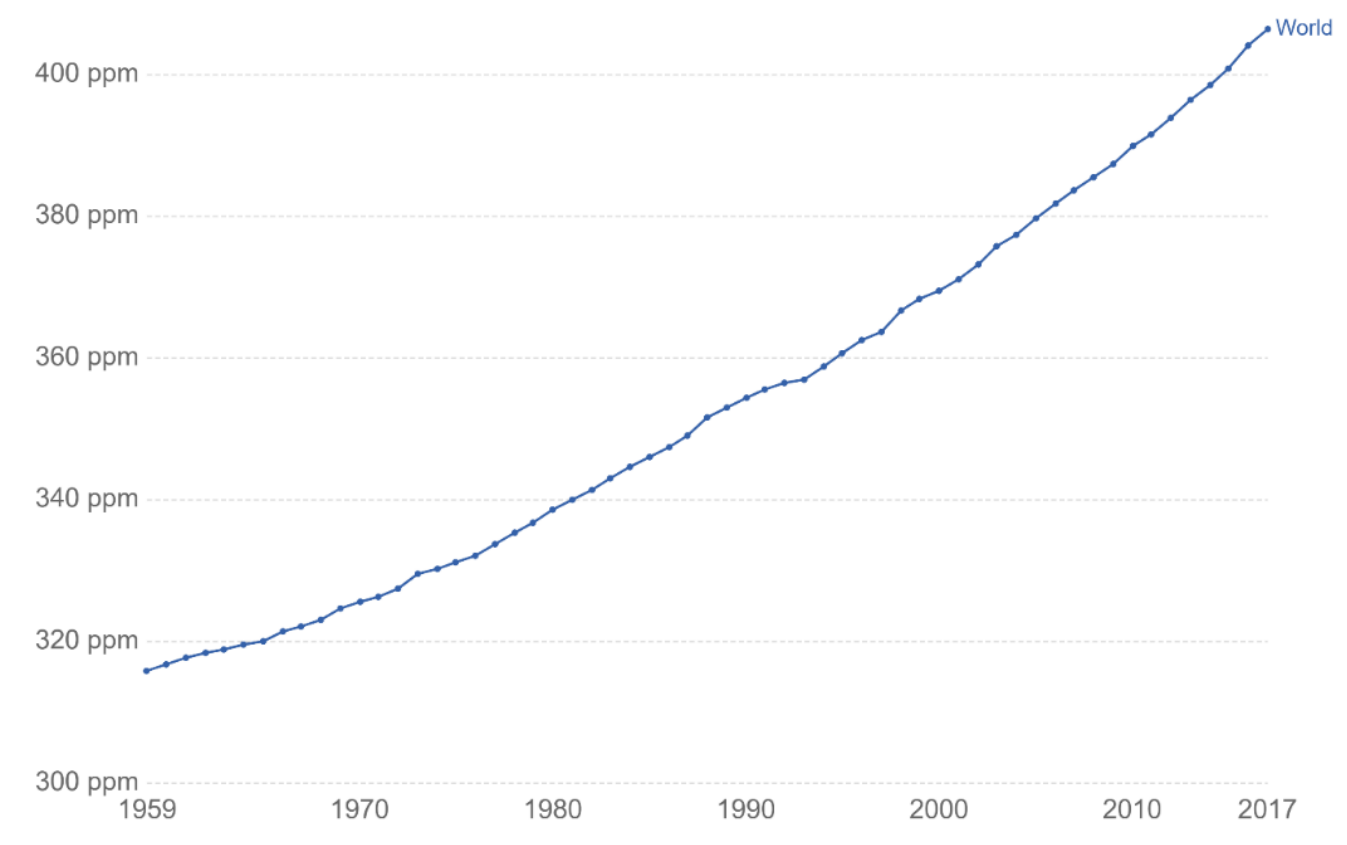

Figure 1.2: Global $\mathrm{CO}_{2}$ atmospheric concentration [2].

For example there is about $600 \%$ increase in the investment in renewable energy between 2004 and 2015 as seen in Figure 1.3 [4], and the major investments are in solar and wind over the past few years. However, these resources are not available at all times and require costly and complicated devices to store energy, while geothermal energy is available at all times, more reliable, easily scalable, and provides a significant amount of energy [5]. Nationally, it has been estimated geothermal, as of 2007, contributes $0.5 \%$ of the total U.S. energy demand [6] and as of 2018, constitutes only $2 \%$ of the total renewable energy consumption in the U.S. [7]. 


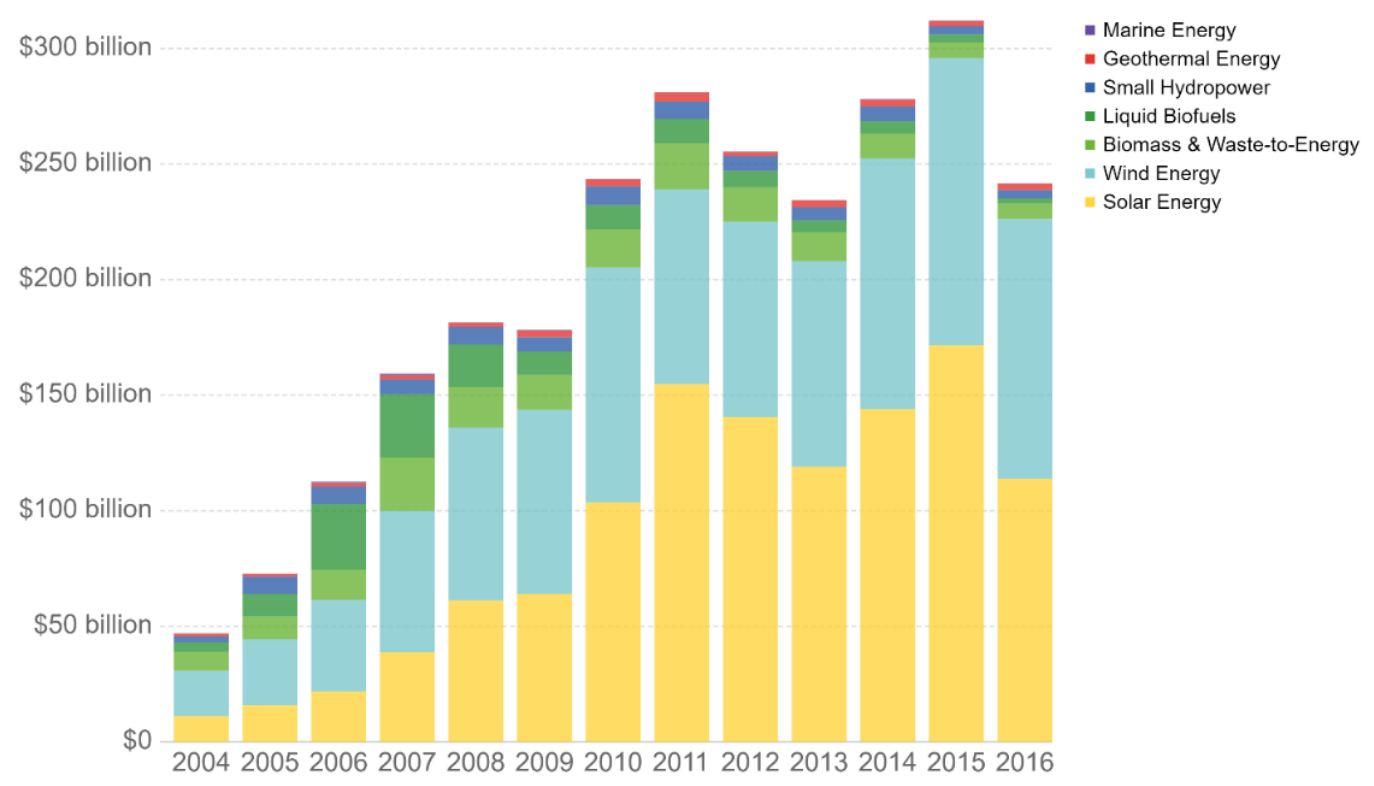

Figure 1.3: Global investment in renewable energy technologies [3].

\subsection{Geothermal Energy as a Renewable Energy Source}

The word geothermal is derived from two words geo (earth) and therme (heat). Geothermal energy is a renewable energy source, as heat is continuously generated inside the earth. Geothermal energy has been used by Native American cultures, Chinese and Roman for heating, cooking, bathing, and spas. In the last century, heat energy beneath the earth's surface has been harnessed by people as steam or hot water to heat their homes, blocks of buildings, and to generate electricity. Geothermal energy is being used today in three major areas: electricity generation in power plants, direct-use and district heating systems, and geothermal heat pumps [8]-[10]. For power generation, high temperature geothermal fluid is passed through a turbine to produce electricity while direct utilization of geothermal energy refers to various forms of heating and cooling. The principal areas of direct utilization are: district heating and cooling including space heating and heating of swimming pools, agriculture applications like greenhouse heating and crop drying, aquaculture pond applications, industrial processes, and heat pumps [11]. According to Tester et al. [12], the potential for geothermal direct-use in the U.S. is enormous [12]. The direct-use applications of geothermal district heating has been extensively documented [9], [13]-[15].

The geothermal temperatures $\left(<150^{\circ} \mathrm{C}\right)$ required for direct-use are generally lower than those of electricity generation $\left(>150^{\circ} \mathrm{C}\right)$. Fox et al. [16] carried out a detailed study of the U.S. yearly 
energy consumption as function of its utilization temperature from 0 to $260^{\circ} \mathrm{C}$ ( Figure 1.4 ) and found about $25 \%$ of U.S. total primary energy demands are for thermal energy uses at temperatures below $120^{\circ} \mathrm{C}$ [16], [17]. The energy for these low-temperature end uses are currently provided by fossil fuel combustion, though the combustion temperatures of fossil fuels are too high for these applications. For example, a large percentage of energy needed for space and water heating are at low temperatures but are provided by combustion of oil and natural gas at high temperatures and downgrading of these resources results in exergy losses. Geothermal energy, on the other hand, has a potential to supply these thermal energies sustainably with minimal exergetic losses. Furthermore, geothermal direct-use provides a more efficient energy utilization because there is no thermodynamic second law efficiency loss that occurs in converting thermal energy to electricity.

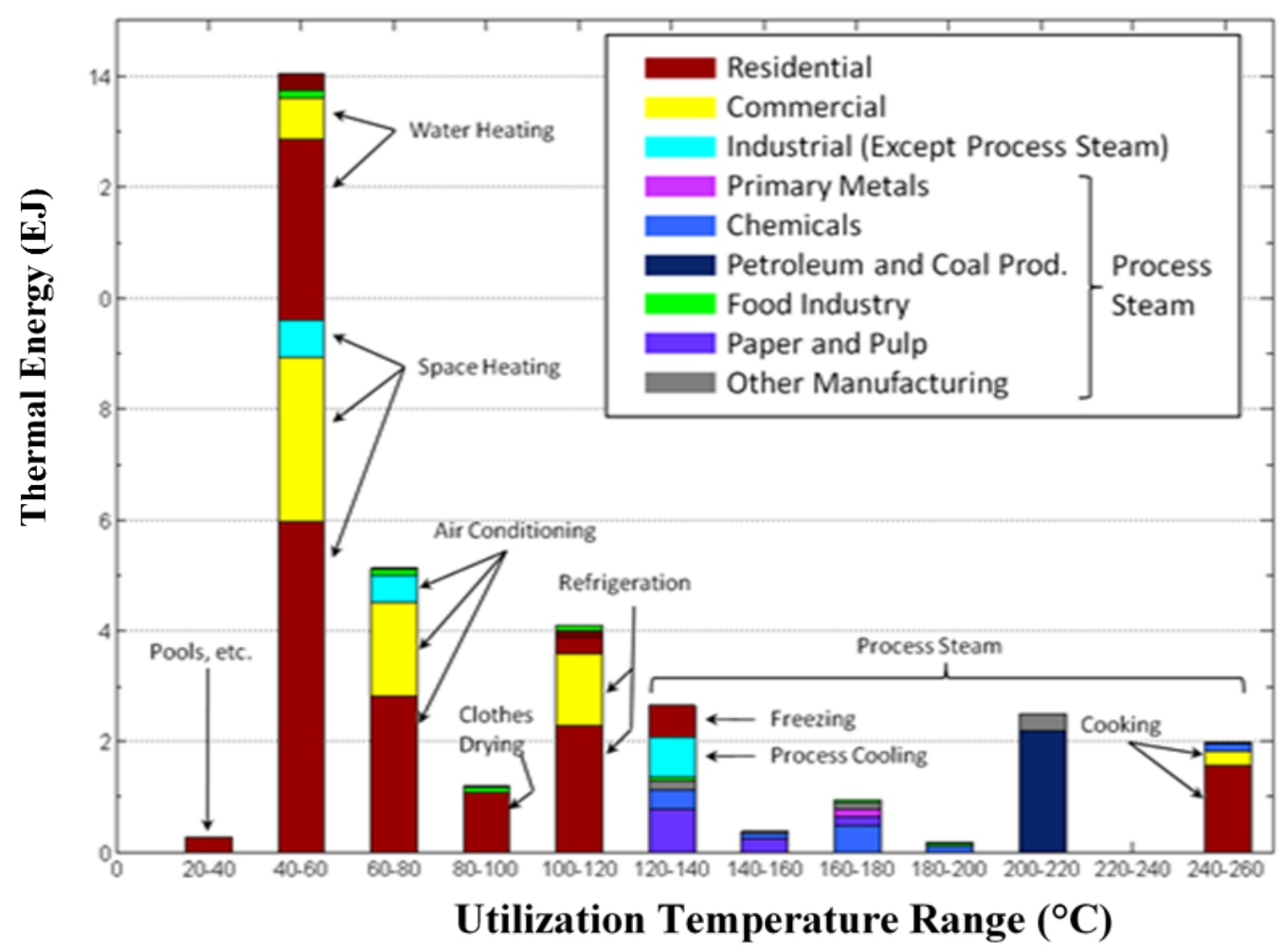

Figure 1.4: Thermal energy use temperature distribution from 0 to $260^{\circ} \mathrm{C}$ [16].

Currently, most U.S. geothermal power plants and direct-use applications are installed in California, Nevada, and Idaho where there exists high geothermal temperature gradients and 
relatively shallow fracture networks in the subsurface [18]. However, recent studies from Southern Methodist University (SMU), as a part of their project to update the geothermal heat flow map (Figure 1.5) of North America [19], discovered temperatures beneath the state of West Virginia are significantly higher than those previously estimated in Massachusetts Institute of Technology (MIT) "The future of Geothermal Energy" report [20]. This high temperature region extends from north-central West Virginia (Monongalia County), to southeastern West Virginia (Greenbrier County). Based on the Low-temperature Geothermal Play Fairway Analysis in Appalachian region, the elevated temperatures under Morgantown are sufficiently hot enough and capable of supporting commercial geothermal systems for direct-use applications [21].

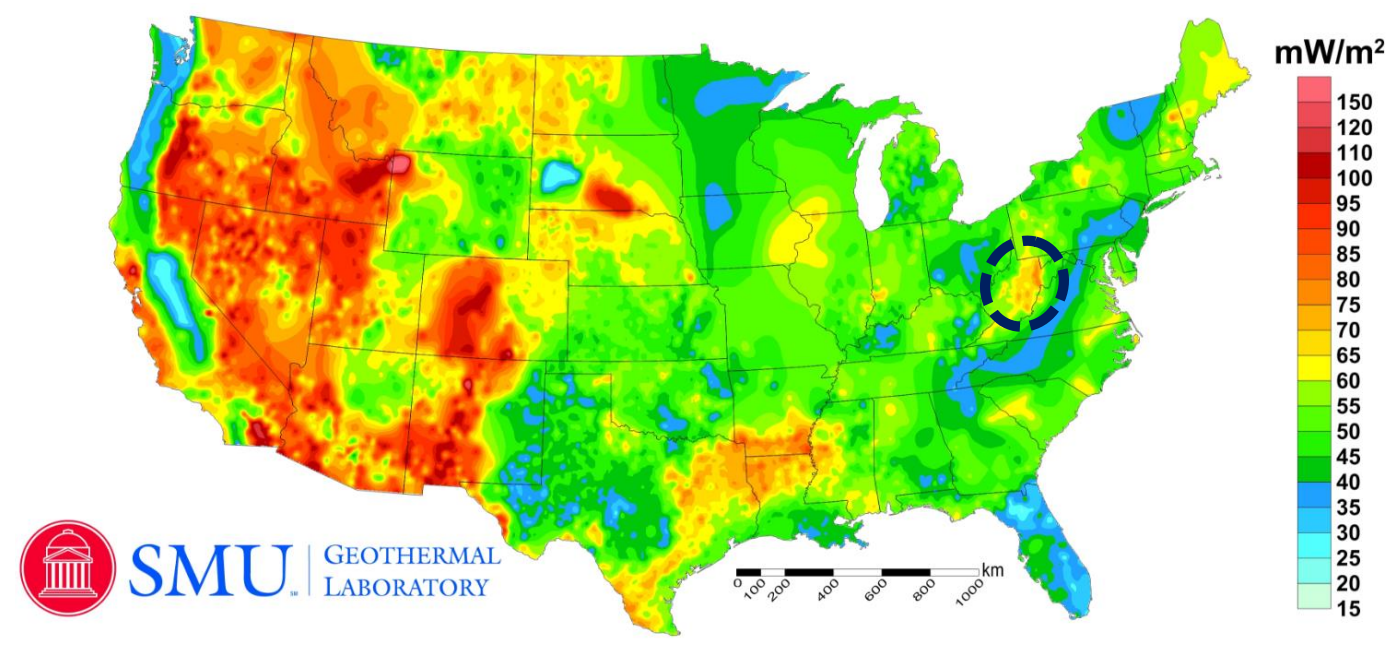

Figure 1.5: The updated heat flow map of the conterminous United States [19], the circle represents West Virginia.

The Tuscarora Reservoir is selected as an ideal site for geothermal development as it has been estimated to have a sufficient temperature and geofluid flowrate which are identified as the two most critical factors in minimizing cost of developing a geothermal system according to the "Future of Geothermal Energy" [20]. An ongoing project led by WVU and funded by the Office of Fossil Energy called the "Marcellus Shale Energy and Environment Laboratory (MSEEL)," has provided access to new geothermal gradient data using a downhole fiber optic cable. From this project, measured background geothermal temperatures in the Morgantown area at 7,500 $\mathrm{ft}$ (2,286 m) depth are $167-170^{\circ} \mathrm{F}\left(75-77^{\circ} \mathrm{C}\right)$. Therefore, the extrapolated temperature of the Tuscarora at $10,000 \mathrm{ft}$ will be approximately $211^{\circ} \mathrm{F}\left(\sim 100^{\circ} \mathrm{C}\right)$. Along with potential temperature gradient, 
significant porosity and permeability is expected, based on resistivity logs and gas production history in this area. Deep direct-use geothermal development requires an additional critical factor for economic viability: available thermal demand and appropriate surface distribution infrastructure. The market for the geothermal resource in Morgantown will be the commercial and residential sectors of the WVU campus, comprising 1,892 acres; 245 buildings; and 30,000 faculty, staff, and students. Hence, the WVU campus offers surface demand coupled with potential subsurface viability.

\subsection{Objectives and Approach}

The main goal of this project was to perform a feasibility analysis of developing a geothermal district heating and cooling (GDHC) system for the WVU campus in Morgantown WV to replace the current coal-fired steam heating and cooling system, which serves over a 30,000 student, faculty and staff population spread across more than 1,800 acres with 245 campus buildings. The steam to the campus loop is currently provided by Morgantown Energy Associates (MEA), a coalbased power plant. The sustainability plan, managed under the Office of Sustainability and the WVU Energy Institute, aims to advance the efforts of WVU to achieve a reliable and clean energy source for their central steam generation system. Geothermal is identified as one of the potential options.

The heating and cooling system at WVU is unique due to the year-round use of steam for heating in winter and cooling in the summer months using absorption cooling. Therefore, the use of geothermal heating at WVU would result in year-round utilization of the deep direct-use (DDU) system, hence lowering the levelized cost of heat ( $\mathrm{LCOH}$ ) by fully amortizing the system over 12 months thus providing the first demonstration of the practical feasibility and effectiveness of a geothermal system in the eastern U.S.

The specific objectives of this study:

1. Objective 1: Characterize energy demand for the WVU campus. The year-round energy consumption data of the WVU campus is collected to characterize the energy demand.

2. Objective 2: Evaluate existing campus district heating system retrofit capability.

3. Objective 3: Design a geothermal surface plant and pipeline distribution using Aspen simulators. 
4. Objective 4: Perform an economic analysis to estimate the levelized cost of heat (LCOH) using GEOPHIRES (GEOthermal energy for Production of Heat and electricity ("IR") Economically Simulated) [22].

The feasibility of the hybrid GDHC system at WVU was determined by comparing costs and benefits with the existing MEA coal-fired steam-based system.

\subsection{Thesis Structure}

In chapter 1, background information about geothermal energy system in U.S. is discussed. Chapter 2 reviews development of GDHC system in US and provided the overview of the existing district heating and cooling (DHC) system at the WVU. The first and second objectives make up chapter 3 of this thesis. In objective 1 data were collected over the project period to provide information about the temperature, pressure and flow rates from the existing surface facilities, analysis from objective 2 provides information about the required new set of equipment and distribution pipelines which are not part of the current surface plant facilities for the coal-fired steam-based system. Chapter 4 describes geothermal surface plant and distribution pipeline simulation setup. In chapter 4, the data and new sets of equipment identified from Chapter 3 are used for the HYSYS simulations. Aspen Exchanger Design and Rating (EDR) and Aspen capital cost estimator (ACCE) methodologies are also described in chapter 4. In chapter 5, HYSYS simulation results are presented and the results obtained from HYSYS simulations provide the inputs required to perform rigorous design in Aspen EDR for geothermal plate heat exchanger and shell and tube heat exchanger for fuel preheater. Chapter 5 uses Aspen ACCE to provide the costs associated with the surface plant equipment and distribution pipelines. The main goal of chapter 6 is to perform an economic evaluation of the entire project using GEOPHIRES software and the resulting levelized cost of heat $(\mathrm{LCOH})$ is used to assess the feasibility of the hybrid GDHC system at WVU. Furthermore, a comparison is made between natural gas boiler system and a hybrid geothermal-natural gas system to identify (analyze) which of the two systems could potentially replace the current MEA coal-fired steam-based system. Chapter 7 provides future directions and recommendations for further works. 


\section{Literature Review}

\subsection{Development of Geothermal District Heating and cooling (GDHC) System in US.}

The first U.S. geothermal district heating system (GDHS) was developed in the winter of 1890 in Boise, Idaho [14] .The two wells were drilled to supply geothermal hot water at $77^{\circ} \mathrm{C}$ and a network of wooden pipelines were constructed to transport hot water produced from the well to the various buildings in the town of Boise. Thus, Boise Water Works was able to supply customers heat energy for space heating in addition to drinking water. Over the years, about 22 GDHS have been developed in the U.S. [23]. The majority of the district heating and cooling systems are located in the western states of U.S., as shown in Figure 1.1. In spite of over one century since the development of first geothermal system in the U.S., there has been a slow growth in the development of GDHS systems compare to Europe [24], [25] and other countries like Iceland where geothermal supplies over $90 \%$ of the Iceland space heating demand [26].

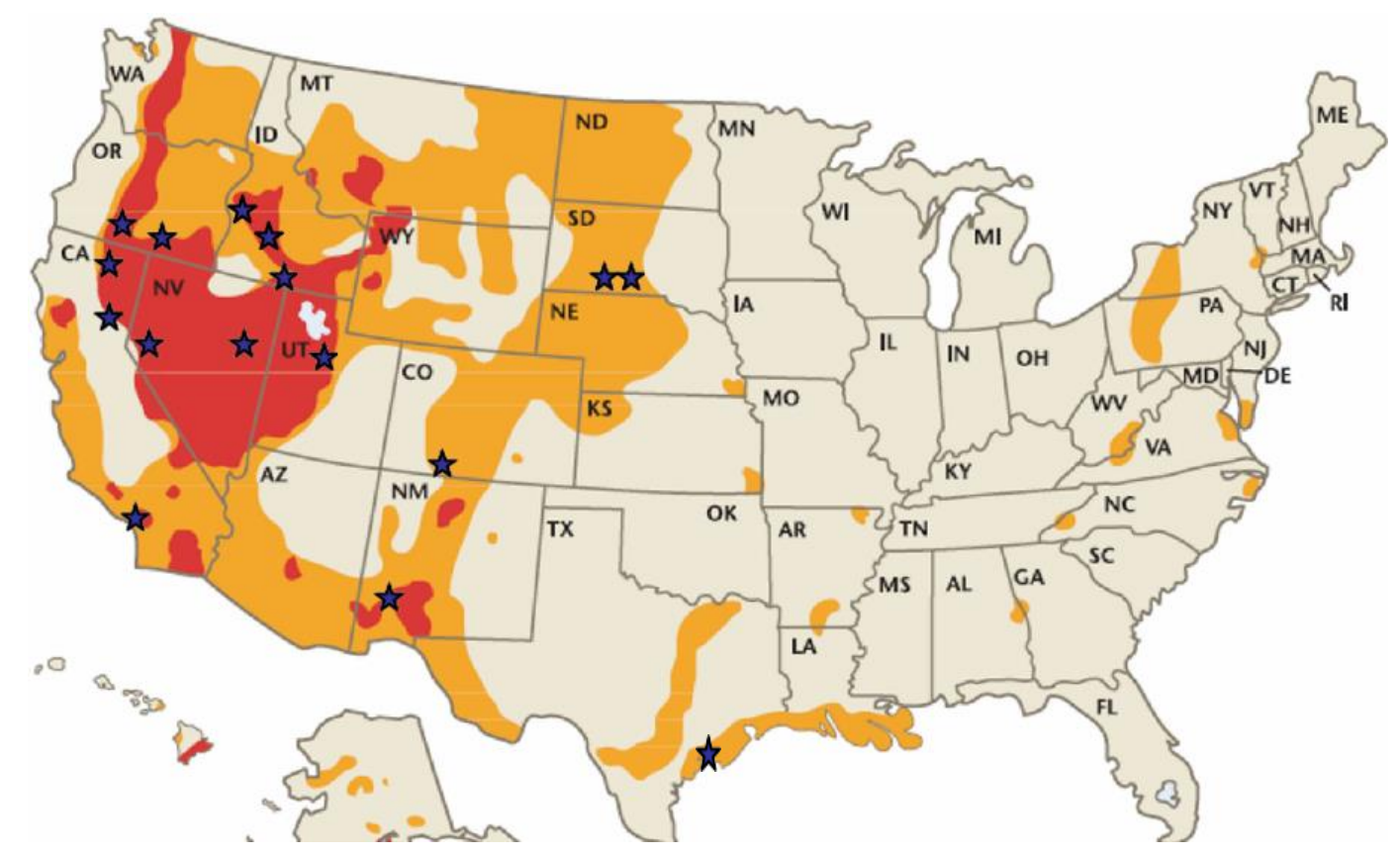

Figure 2.1: The locations of geothermal district heating system in US [27].

Geothermal district heating and cooling system is underdeveloped in the U.S. despite its enormous potential to provide clean energy as a way to offset fossil fuel emissions [28], [29]. Technical, economic, and regulatory policy have been identified as the major barriers to the development of geothermal [23], [28], [30]. Thorsteinsson used logistic regression analysis and identified that state 
funding and design problems were the two most significant variables that influence development of successful GDHC system in the U.S. [23]. It has been shown that the development of geothermal district heating system requires a large initial investment in terms of geothermal drilling and exploration and involves significant risks in drilling a geothermal well [31], [32]. In addition to the costs of drilling geothermal well, surface plant equipment costs, scaling and corrosion of equipment, and pipeline infrastructure have been identified to contribute to the barriers for the development of a geothermal district heating and cooling system in U.S. Consequently, the design of a district heating and cooling system at WVU is analyzed to ensure successful development of a GDHC system at WVU.

\subsection{Surface Plant Development}

A geothermal surface plant can be effectively integrated into the existing district heating and cooling system by retrofitting existing DHC system to develop a GDHC [33], [34]. Geothermal heating system is preferably used as the primary source of heat energy in GDHC; but, it could be combined with other forms of energy to provide additional benefits [35]. Depending on geothermal fluid production temperatures, it may be beneficial to develop a hybrid DHC system that includes a heat pump and /or conventional boiler as part of the DHC system design [24], [36]. For example, in certain district heating systems, geothermal energy is used to provide the base-load energy demand and a boiler is used to provide peak-load demand during the winter season [37]-[39]. In a GDHC system where geothermal cannot meet the district heating requirement, fossil fuel (natural gas) or biomass boiler can be used to provide additional heat required to create a system called hybrid GDHC system [40], [41]. In some other cases, geothermal energy utilization could be further improved by using lower-temperature spent geothermal fluid for other purposes including greenhouse and swimming pool heating called heat cascading or multi-stage utilization where lower temperatures are used in sequential steps. For other cases, the performance of geothermal energy utilization in a DHC could be improved by the use of a heat pump system. 


\subsection{Overview of district heating and cooling (DHC) system at WVU}

\subsubsection{Existing Heating and Cooling System at WVU}

The current DHC system at WVU is steam-based. The current system uses steam to heat the water and the hot water is circulated throughout the buildings for heating and domestic usage, while some equipment across campuses like absorption cooling towers and autoclaves require steam for their operation. Ruby Memorial Hospital also requires a significant amount of steam supply for medical purposes in addition to building heat.

\subsubsection{Proposed Heating and Cooling System at WVU}

The expected geofluid from the well cannot meet the campus steam demand because geofluid produced is hot water with temperatures below $100^{\circ} \mathrm{C}$. The conversion of steam-based system to hot water system could be uneconomical and complicated [42]. Therefore, in order to utilize the existing campus heating and cooling facilities, a hybrid geothermal-natural gas system was proposed to supply steam at required conditions. The geothermal fluid preheated the condensate water, which was further heated to required steam conditions using a natural gas boiler. The major components of the proposed hybrid GDHC system include: a centralized geothermal heat exchanger to extract geothermal heat, a heat pump system to further extract more heat from lowtemperature return condensate thereby improving the geothermal extraction and performance of the system, a natural gas boiler to heat hot water to steam, condensate receiver tank, condensate pumps, and retrofitted pipeline networks to transport secondary fluid from the central plant to existing pipelines.

\subsubsection{The Research Study Workflow}

Reservoir parameters (geofluid temperature) and data collected on current campus steam-based system (temperature, pressure, and flow rate) provided the input required to design the proposed hybrid system at WVU, as shown in Figure 2.2. Based on the data collected, two scenarios (Scenario 1 and Scenario 2) were proposed for hybrid DHC systems at WVU. The standard district heating equipment and pipeline distribution networks required for the surface plant development were selected for simulation in Aspen simulator (HYSYS). HYSYS was used to design surface plant facilities for the proposed DHC systems. Detailed equipment design including sizing and rating of heat exchangers was performed in Aspen EDR. The capital costs of the equipment and 
pipelines for the two scenarios were calculated in Aspen ACCE. The total capital costs of equipment and pipelines are used for economic analysis of the hybrid systems in GEOPHIRES. The feasibility of hybrid geothermal-natural gas was determined by comparing the $\mathrm{LCOH}$ of the proposed hybrid systems with the existing coal-fired steam-based system. The workflow for the entire project is summarized in Figure 2.2.

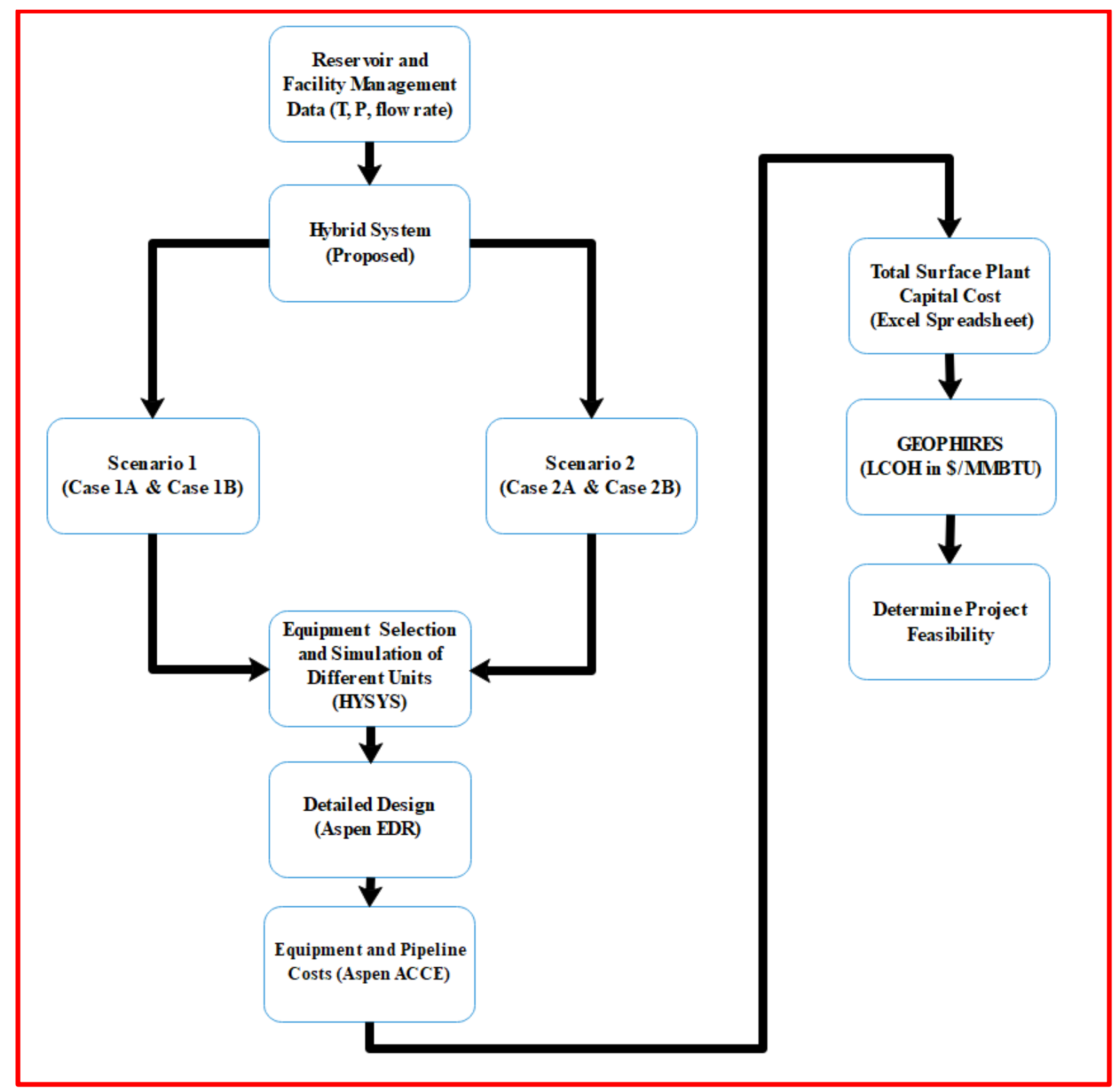

Figure 2.2: A schematic of the workflow for the design and economic analysis of a hybrid GDHC system at $W V U$. 


\section{Characterization of Existing Infrastructure and Evaluation of Existing Campus District Heating (DH) System Retrofit Capability}

\subsection{Objective 1: Characterization of Existing Infrastructure}

The year-round energy consumption data for the WVU campus buildings was collected to characterize the energy demand. Currently, MEA supplies steam to five main distribution points located at three campuses (Downtown, Evansdale and Health Sciences campuses) and the distribution points supply steam directly to the individual building. Thus, flow meter servers were installed at distribution points to record steam temperature, pressure, flow rate, and return condensate flow rate and temperature over a period of one year.

The steam to the campus is distributed through the following five distribution points:

1. Medical Center: Health Sciences campus and Ruby Memorial Hospital

2. Towers: Residential area

3. Evansdale: Engineering and Agriculture buildings

4. Life Sciences: Life Sciences building

5. Downtown: Majority of the campus buildings in downtown area.

\subsection{Objective 1: Results and Discussion}

The existing DHS system involves distribution of heat (steam) to 245 buildings from a centralized coal-fired surface plant owned and operated by MEA. Energy characterization for the three campuses was based on flow metering data. The flow metering data are recorded or logged in 5minute intervals and downloaded monthly to a local computer. The steam flow rates, temperatures, and pressures obtained were used to characterize energy consumed for the individual campus. Figure 3.1 shows steam temperature, pressure, and flow rate for Health Sciences campus (Medical Center meter point) recorded for June 2019.

The annual campus steam consumption for 2017-2018 is shown in Figure 3.2. Steam usage for three-meter points: Medical center, Evansdale, and Downtown meter points dominates annual campus steam demand. The figure also shows that steam usage is maximum during the month of January and minimum during June. 


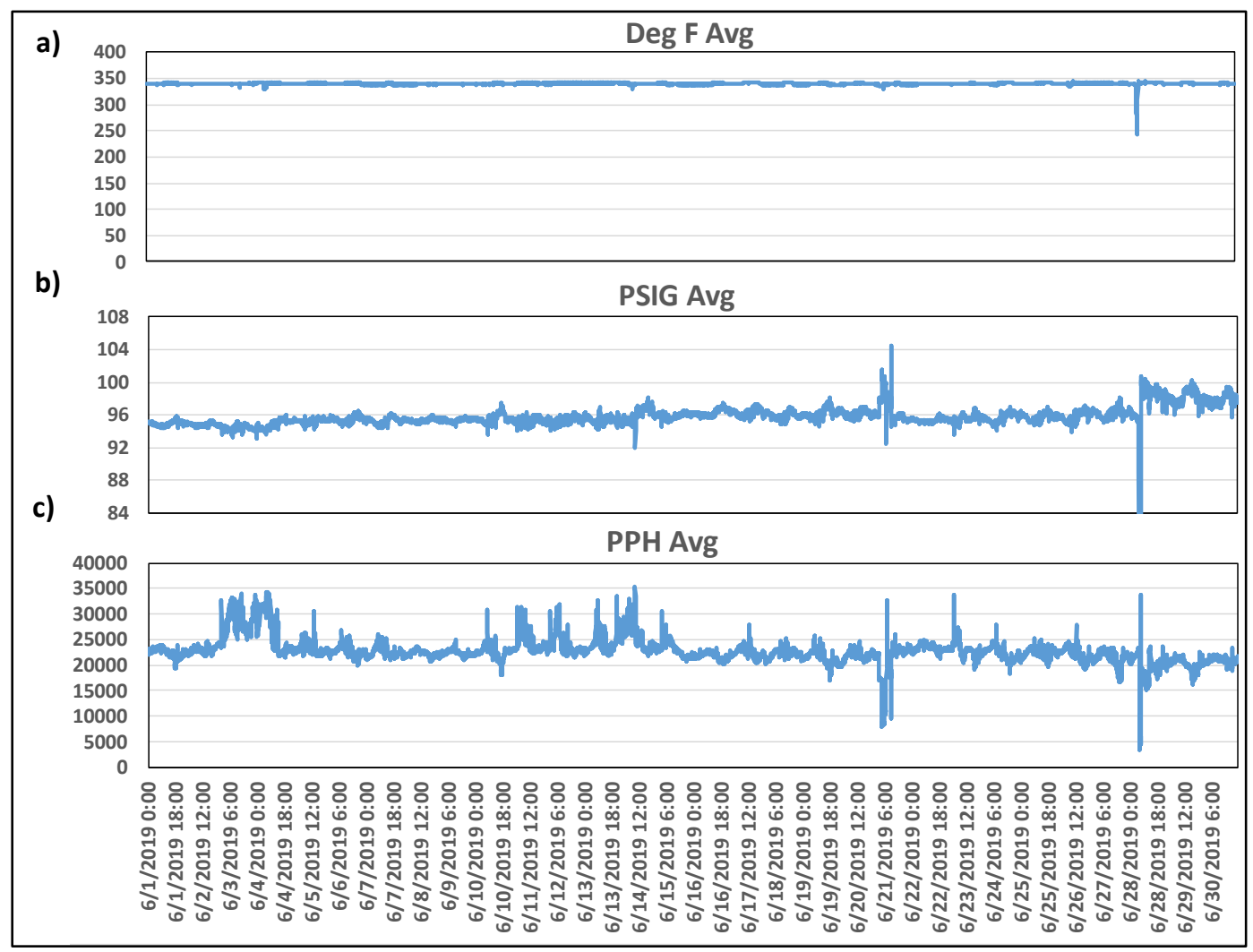

Figure 3.1: WVU steam data for (a) temperature $\left({ }^{\circ} \mathrm{F}\right)(\mathrm{b})$ pressure (psig) (c) flow rate (PPH) for Health Sciences campus (Medical Center meter point) for June 2019.

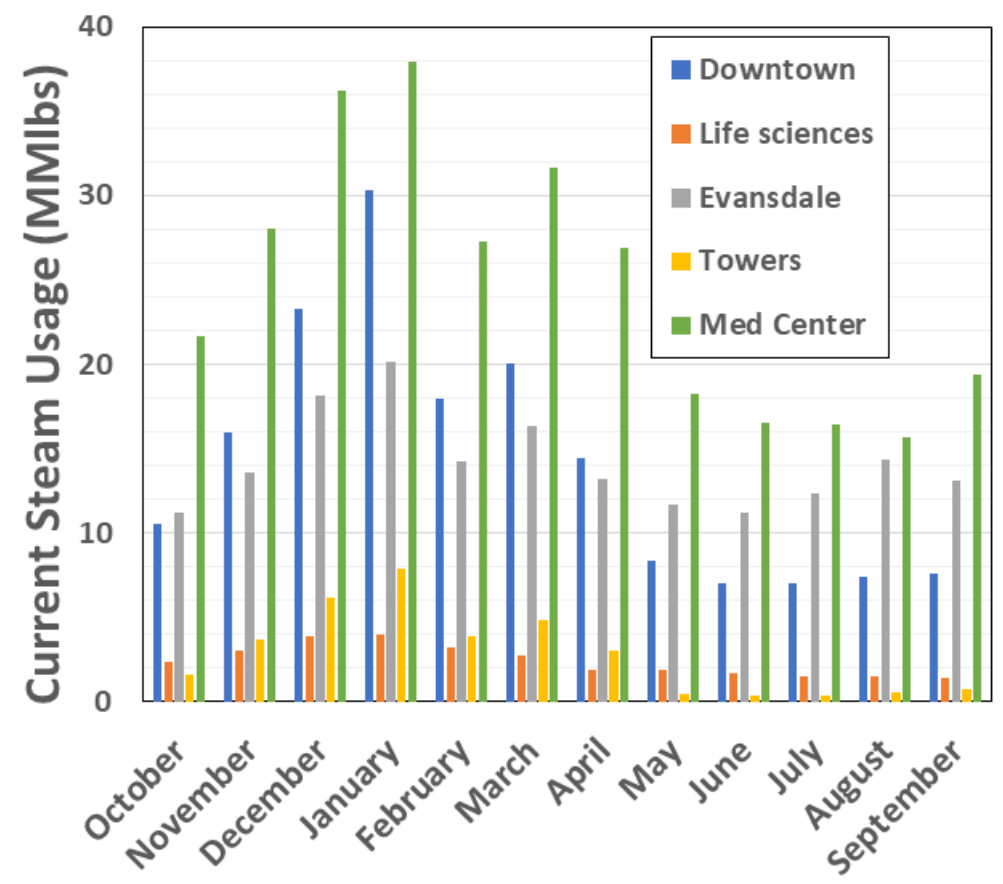

Figure 3.2: Annual WVU campus steam consumption data for the current DHC system at WVU (20172018). 


\subsection{Objective 2: Evaluate Existing Campus District Heating (DH) System Retrofit}

\section{Capability}

For the proposed hybrid GDHC system, existing pipeline distribution networks and the equipment for a DHC system across WVU campuses were evaluated for their retrofit capability. For the surface plant design, existing building infrastructure will be used. However, new equipment required at the centralized surface plant location such as a heat exchanger, a natural gas boiler, a heat pump and a condensate receiver tank to collect return condensate from the five distribution points were evaluated. The new steam and condensate pipelines required to transport steam and condensate produced from the central plant site to the existing pipeline distribution system were identified.

\subsection{Objective 2: Results and Discussion}

The basic equipment required to meet campus steam requirements were identified. The current steam supply pipeline networks from MEA, to individual distribution points is shown in Figure 3.3 along with detailed information about the pipe length, pipe diameter, and the locations of the five distribution points. The pipe lengths are equivalent lengths, which account for bending, valving, and distribution piping system obstructions.

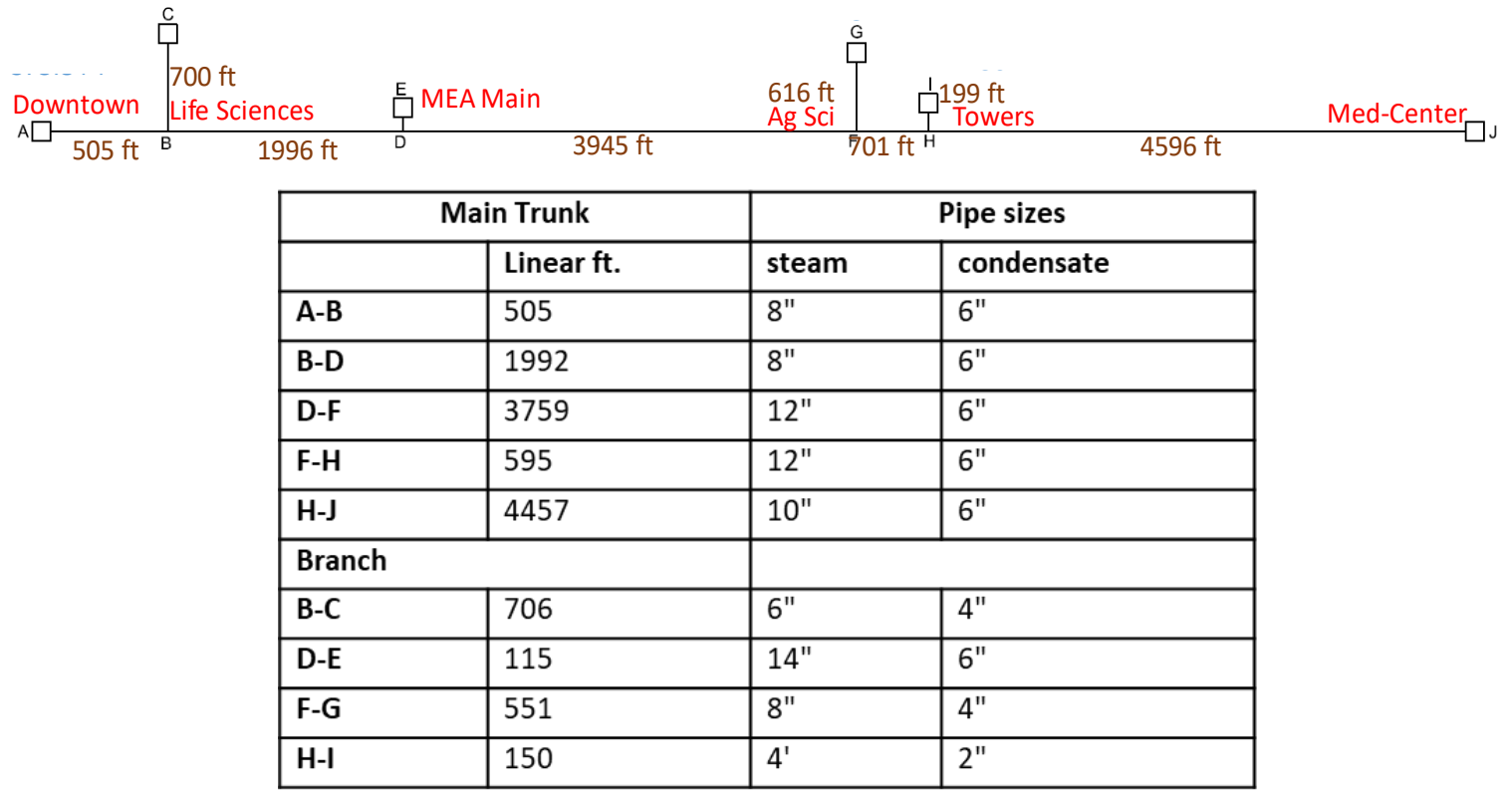

Figure 3.3: One-line drawing of MEA's pipelines with distribution meter points along with linear pipe distances and pipe sizes. 


\section{Objective 3: Design a Surface Plant and Pipeline Distribution Using Aspen Simulators}

\subsection{Proposed Hybrid Geothermal-Natural Gas System Design}

The current campus heating and cooling system is steam-based. The expected geofluid from the well cannot meet the campus steam demand because produced fluid is hot water with temperatures below $100^{\circ} \mathrm{C}$. The current campus heating and cooling system uses steam to heat water and the hot water produced is circulated within the building for heating and domestic usage, while some equipment used across campuses like absorption cooling towers and autoclaves require steam for their operation. Ruby Memorial Hospital also requires a significant amount of steam supply for medical purposes in addition to building heating. In order to use existing steam-based system, a hybrid geothermal-natural gas boiler system was proposed for WVU where geothermal fluid was used to preheat the water and then a natural gas boiler was used to further heat the hot water to provide steam at required conditions.

The surface plant components consist of a geothermal heat exchanger, natural gas boiler, condensate receiver tank, the pumping and distribution pipeline units. Figure 4.1 shows the closed loop configuration and the major components of the surface equipment for the proposed hybrid district heating system at WVU.

From the figure, the surface plant components can be divided into two units: heat production and heat distribution units. Heat production unit includes a centralized heat exchanger, condensate receiver tank and natural gas boiler; and heat distribution unit (mostly fluid distribution lines and associated pumping systems) consists of steam and condensate pipelines. The hot geothermal fluid (GEO-IN) at a fixed temperature and certain flow rate from the production well is first sent to the centralized geothermal plate heat exchanger (PHE) where heat from the hot geofluid is transferred to the condensate entering the heat exchanger (CLD-IN) and the spent geothermal fluid (GEOOUT) is reinjected back into the reservoir. The PHE in Figure 4.1 isolates geothermal fluid from the district heating network to prevent scaling and corrosion in the distribution pipeline networks. The natural gas boiler further heats the hot water to steam at the required conditions and the condensate tank collects the condensate returns from the distribution lines. The distribution line consists of a network of steam and condensate pipelines to transport steam and condensate return 
respectively. To improve heat utilization of the proposed hybrid geothermal-natural gas boiler system, heat pump system is integrated into the surface plant components in Figure 4.1.

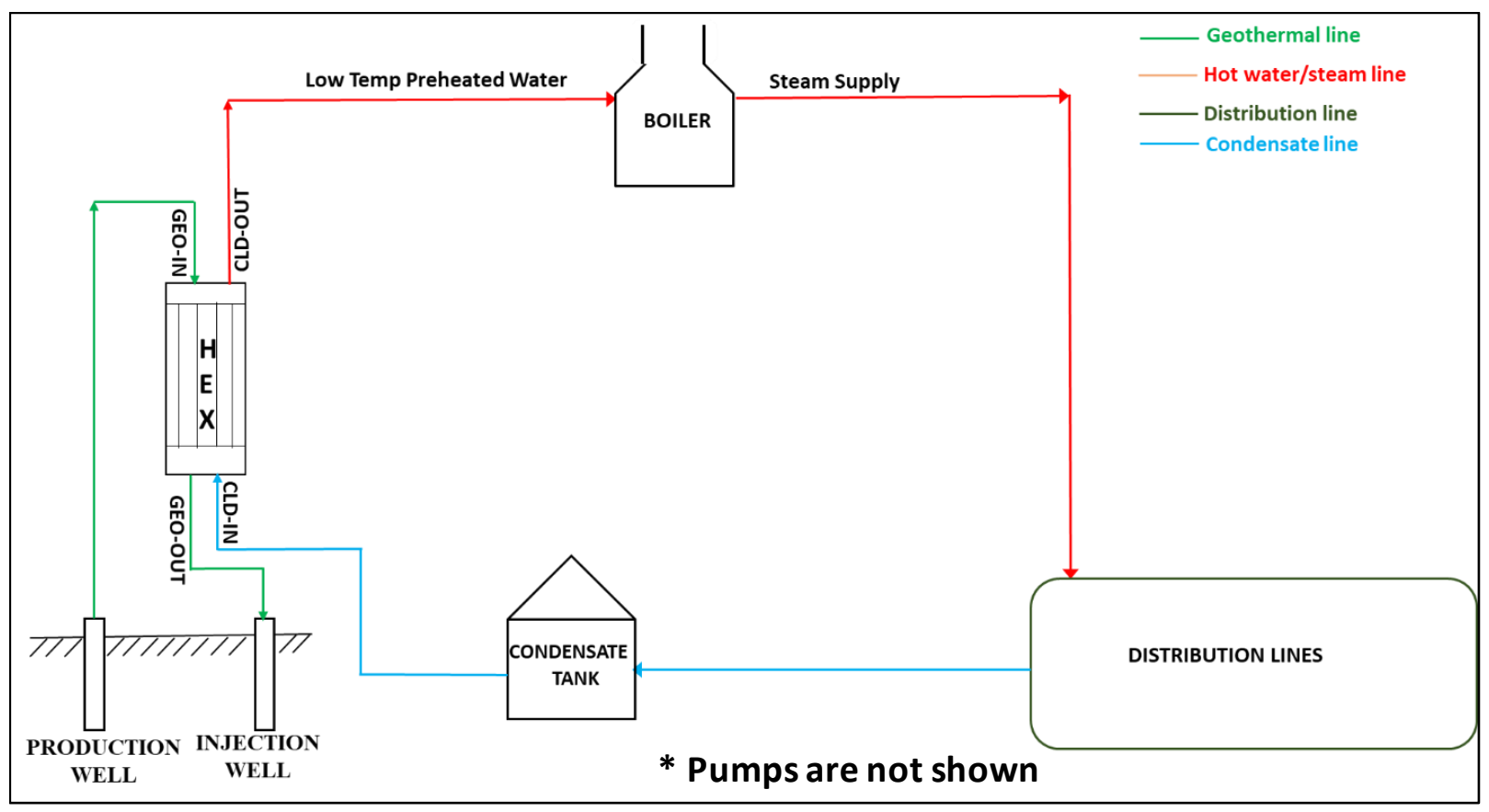

Figure 4.1: Schematic of the proposed hybrid geothermal-natural gas boiler systems for West Virginia University.

For the proposed hybrid geothermal-natural gas boiler system with heat pump system, the heat pump system is used to improve the heat utilization by extracting heat from low-temperature condensate return such that geothermal energy extraction is maximized, and the heat extracted by the heat pump is used to further heat the hot water before sending it to the boiler as shown in Figure 4.2 below. In heat pump, the working fluid inside the evaporator evaporates by extracting heat from low-temperature water returning from the campus distribution loop before the condensate is sent back to the geothermal PHE (CLD-IN). The compressor increases the pressure of the working fluid before it is then condensed at a high temperature and pressure inside the condenser during which condenser rejects the heat absorbed by the working fluid to provide additional heat needed to raise the temperature of geothermally preheated water. 


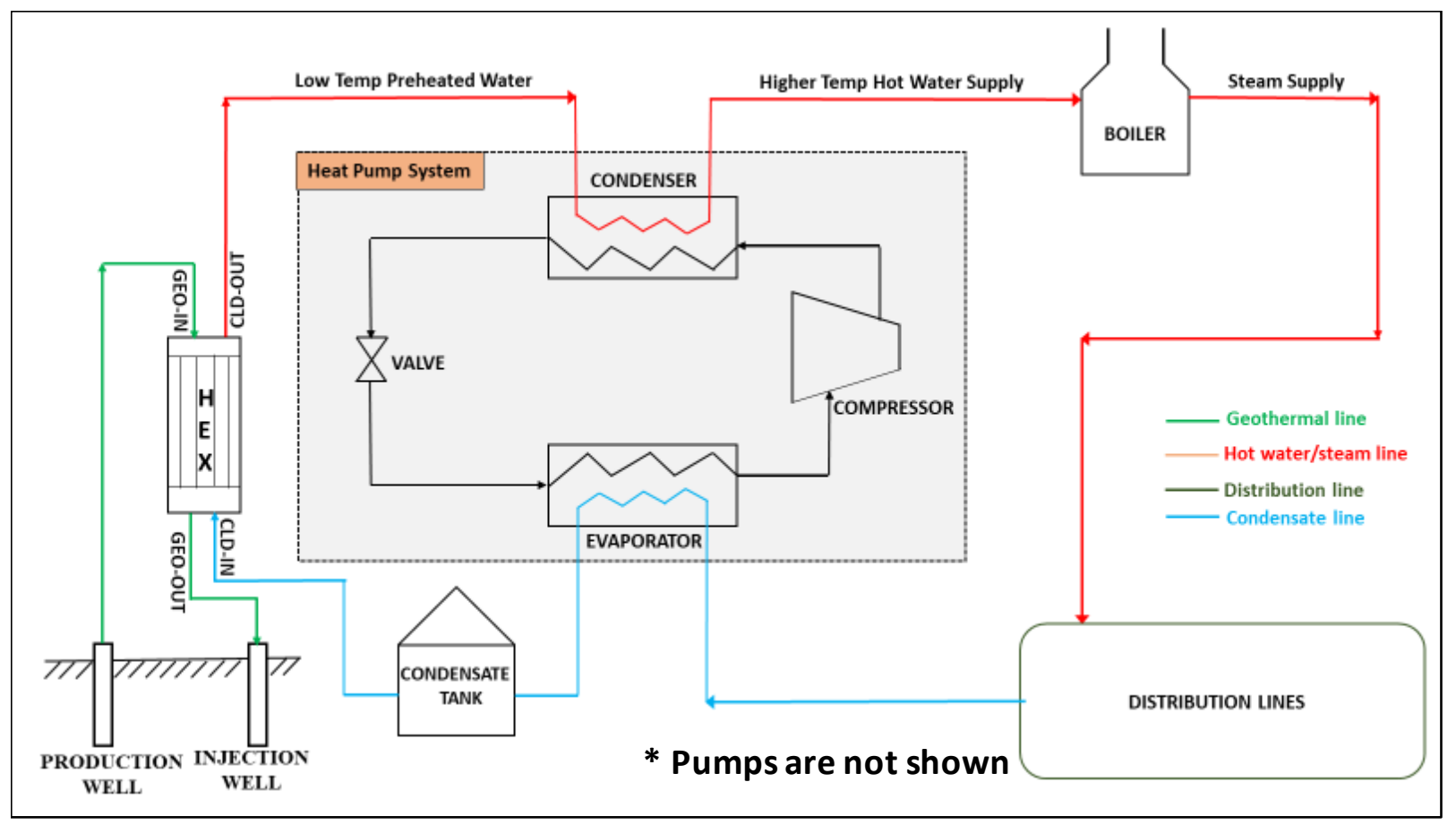

Figure 4.2: Schematic of the proposed hybrid geothermal-natural gas boiler system improvised with heat pump system for West Virginia University.

High temperature hot water leaving the heat pump system is pressurized by a hot water pump (not shown in the figure) before it is sent to the natural gas-fired boiler, where it is further heated to produce steam at required conditions. The steam (superheated or saturated steam) supplied to the distribution points is sent to individual buildings at WVU for domestic use and heating and cooling purposes (space heating). As the steam passes through the building, the steam condenses, and the condensate produced is eventually returned back to respective distribution points. Again, from the distribution points, a network of condensate pipelines is used to transport the condensate produced back to the centralized surface plant for re-use by the centralized heat exchanger. The condensate receiver tank collects all the condensate return to be recirculated back through the loop. For the distribution lines, a system of condensate pumps is used to re-circulate condensate back to the central plant site.

The proposed GDHC system design was based on the location of the proposed geothermal well (HSC) as shown in Figure 4.3 and steam demand at the West Virginia University campus. Two design scenarios were considered for the hybrid district heating and cooling system at WVU: 
- Scenario 1: supply steam to entire WVU campus (all five distribution points). Scenario 1 involves two cases: Case 1A and Case 1B. In Case 1A, single boiler (Boiler1) provides high pressure steam at $18.25 \mathrm{bar}(250 \mathrm{psig})$ and $260^{\circ} \mathrm{C}\left(500^{\circ} \mathrm{C}\right)$ to the entire campus while Case 1B has a boiler (Boiler1) and a compressor. For Case 1B, Boiler1 provides superheated steam at $14.5 \mathrm{bar}(195.6 \mathrm{psig})$ and $200^{\circ} \mathrm{C}\left(392^{\circ} \mathrm{C}\right)$ to the entire campus except Life Sciences where the compressor provides superheated steam at 18.25 bar and $260^{\circ} \mathrm{C}$ to the Life Sciences meter point.

- Scenario 2: supply steam to Health Sciences (Medical Center meter point) and Evansdale campuses. Again, Scenario 2 also involves two cases: Case 2A and Case 2B. In Case 2A, the only boiler (Boiler1) provides saturated steam at 12.5 bar (166.6 psig) to Health Sciences and Evansdale (Evansdale and Towers meter points) whereas Case 2B has two boilers; Boiler1 provides saturated steam to Health Sciences and Evansdale meter point at 12.5 bar (166.6 psig) and Boiler2 provides low pressure saturated steam to Towers meter point at 2.75 bar (25.2 psig).

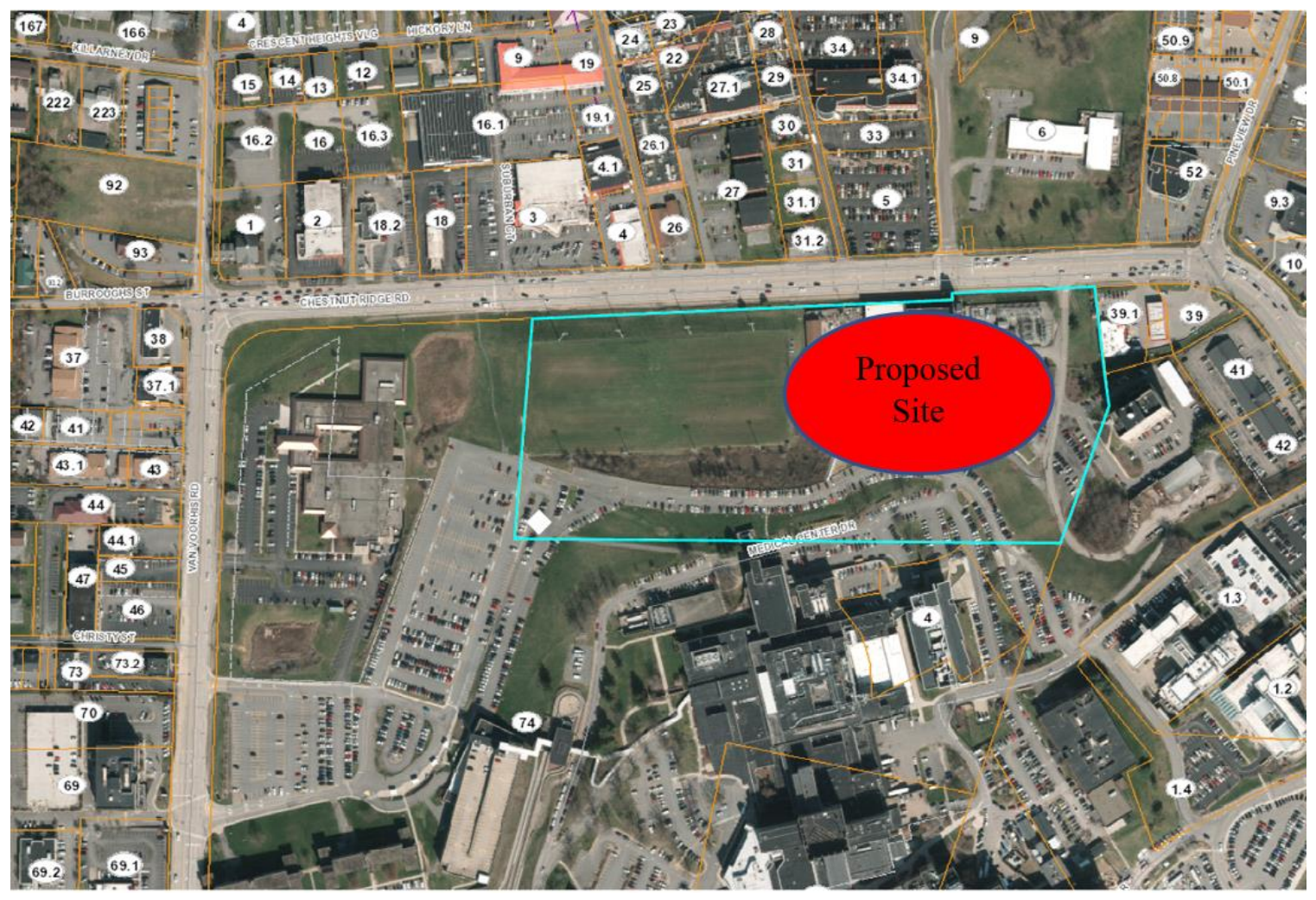

Figure 4.3: The aerial view of the proposed geothermal well site location at Health Sciences. 


\subsection{Geothermal Heat Exchanger Unit}

The objective was to design a geothermal plate heat exchanger that takes in hot geothermal fluid at $15.2 \mathrm{~kg} / \mathrm{s}$ for Scenario 1 and $10.2 \mathrm{~kg} / \mathrm{s}$ for Scenario 2 to heat condensate water. For all cases considered in this work, a PHE was used to isolate the geothermal fluid because PHE is the most commonly used in various geothermal applications as geothermal fluid is corrosive and fouling and hence, the ease of cleaning makes PHE superior to shell and tube heat exchanger (STHE) [43], [44].

To simulate PHE, first heat exchanger model "Simple End Point" in HYSYS was used to run the basic simulations. To carry out rigorous design of the PHE and make necessary corrections for fouling and allowable pressure drop requirements, the process data in HYSYS is exported to Aspen EDR as in chapter 5. The material of construction is assumed to be stainless steel SS-304 to provide corrosion resistant to the PHE [43]. For the four cases considered in this work, the process data in HYSYS is exported to Aspen EDR in chapter 5 where detailed The STHE area, tube passes, number of tubes, tube pattern, Tubular Exchangers Manufacturers Association (TEMA) shell and heat types, and estimated shell and tube pressure drops were determined from Aspen EDR rigorous design. The material of construction is assumed to be carbon steel to provide enough strength for the high temperature flue gas inlet to the STHE. The simulation run mode in Aspen EDR (chapter 5 ) is then used to determine the range of values for the allowable pressure drops for the hot and cold streams which was estimated as 0.02 bar. The estimated pressure drop is used in rigorous design of the PHE.

Geothermal fluid contains many dissolved chemicals that are corrosive to construction materials. The chemical composition of a geothermal fluid varies widely and is largely dependent on the geochemistry of the geothermal reservoir. Although geothermal fluid has a wide variety of compositions, in this work, the geothermal fluid was assumed to be a pure water and hence, geothermal fluid was simulated as a pure fluid in HYSYS. Additionally, the built-in fluid property correlations in GEOPHIRES for density, heat capacity, viscosity, and vapor pressure are based on the assumption of pure water [45]. However, to account for geothermal fouling of the heat exchanger, a typical fouling resistance for geothermal fluid $\left(0.0007 \mathrm{ft}^{2}-\mathrm{h}-{ }^{\circ} \mathrm{F} / \mathrm{BTU}\right)$ [46] obtained 
from the literature was used in rigorous design of the heat exchanger. The value for the condensate fluid fouling resistance $\left(0.0001 \mathrm{ft}^{2}-\mathrm{h}-{ }^{\circ} \mathrm{F} / \mathrm{BTU}\right)$ was based on the assumption that the condensate is a soft water [43].

\subsection{Fired heater simulation in HYSYS}

The three major sections of the fired heater available in HYSYS (AspenTech) are:

- Radiant Section: consists of a firebox which transfers heat to the heater tubes mainly by radiation from high-temperature flue gas;

- Convection Section: consists of a bank of tubes which receives heat from the hot flue gases, primarily by convection; and

- Economizer: used to heat the water fed to the boiler. Economizer is primarily used to recover heat from the boiler flue gases to increase boiler efficiency.

At steady state, HYSYS fired heater does not have convection and economizer sections. Fired heater is typically designed with a suitable size, material, and heat of combustion; but, in the case of this work, HYSYS fired heater simulation is for basic mass and energy balance to provide boiler heat duty, air-fuel flow rates, and the required steam outlet temperature and pressure at saturated or super-heated conditions which are required to obtain boiler costs from suitable vendors and to estimate boiler costs in Aspen ACCE.

Fired heater has four basic components: fire box, burner, convection coil and stack. In the HYSYS steady state simulation, there is no burner, convection coils, and stack components. Because only radiative section is active in steady state, no other significant modification or specification was done for the steady state simulations. Vacuum or negative pressure conditions required for the boiler operation are not available at steady state; but, the combustion of air and natural gas is assumed to occur at near atmospheric pressure of about 0.8 bar [47]. For the minimum (lowest) possible utility cost, the fired heater is assumed to operate at $85 \%$ efficiency in order to maximize fuel usage. This means $85 \%$ of the heat is absorbed in the radiant section of the fired heater while the remaining $15 \%$ goes into heating exiting flue gas. Hence, fired heater efficiency for the radiant section is defined as the ratio of heat supplied to the process fluid to the total heat supplied to the process fluid and flue gas exiting the stack. Stack consists of a cylindrical brick shell which 
transports flue gas to the atmosphere and provides necessary draft. As there is no stack section, no damper is simulated to regulate flue gas flow through the stack or duct and to control draft or negative pressure (vacuum) in the fired heater as damper is not available for the steady state simulations. Draft (forced, induced or natural draft), which involves the use of a fan to supply combustion air to the burner and to overcome the pressure drop through the burner, is simulated as the air blower in HYSYS. In the HYSYS simulation, natural gas preheater is not available; but it is simulated using shell and tube heat exchanger where fired heater exiting flue gas is used to preheat the industrial natural gas supplied before the preheated natural gas enters the fired heater combustion section (burner).

Factors affecting the performance of the fired heater including the heat burner capacity, air leakage, negative pressure, economics, and safety are not considered in the steady state simulations. The flue gas temperature is assumed to be around $385^{\circ} \mathrm{C}$ [47], [48] which is considered to be high enough to prevent condensation of the flue gas at dew point.

The objective here was to simulate a natural gas boiler for a given process condition applicable to the WVU campus district heat supply. The pressure of the preheated water coming from the GEOHEX was at 1 bar. However, Scenario 1 and Scenario 2 fired heater simulations require steam supply at higher pressure conditions in order to meet steam requirements at the distribution points. To achieve the required steam condition at the distribution points, geothermally preheated high temperature hot water supply was pumped into the fired heater via a pump (PUMP-1) while natural gas combustion in the burner provided additional heat energy required to produce superheated steam (Case 1A \& 1B) and saturated steam (Case 2A \& 2B). The steam produced was then sent to the various campuses through a network of underground, buried insulated pipelines which extend from the centralized surface plant at the well location to the individual campuses. HYSYS simulated boiler unit is shown in Figure 4.4 below. 


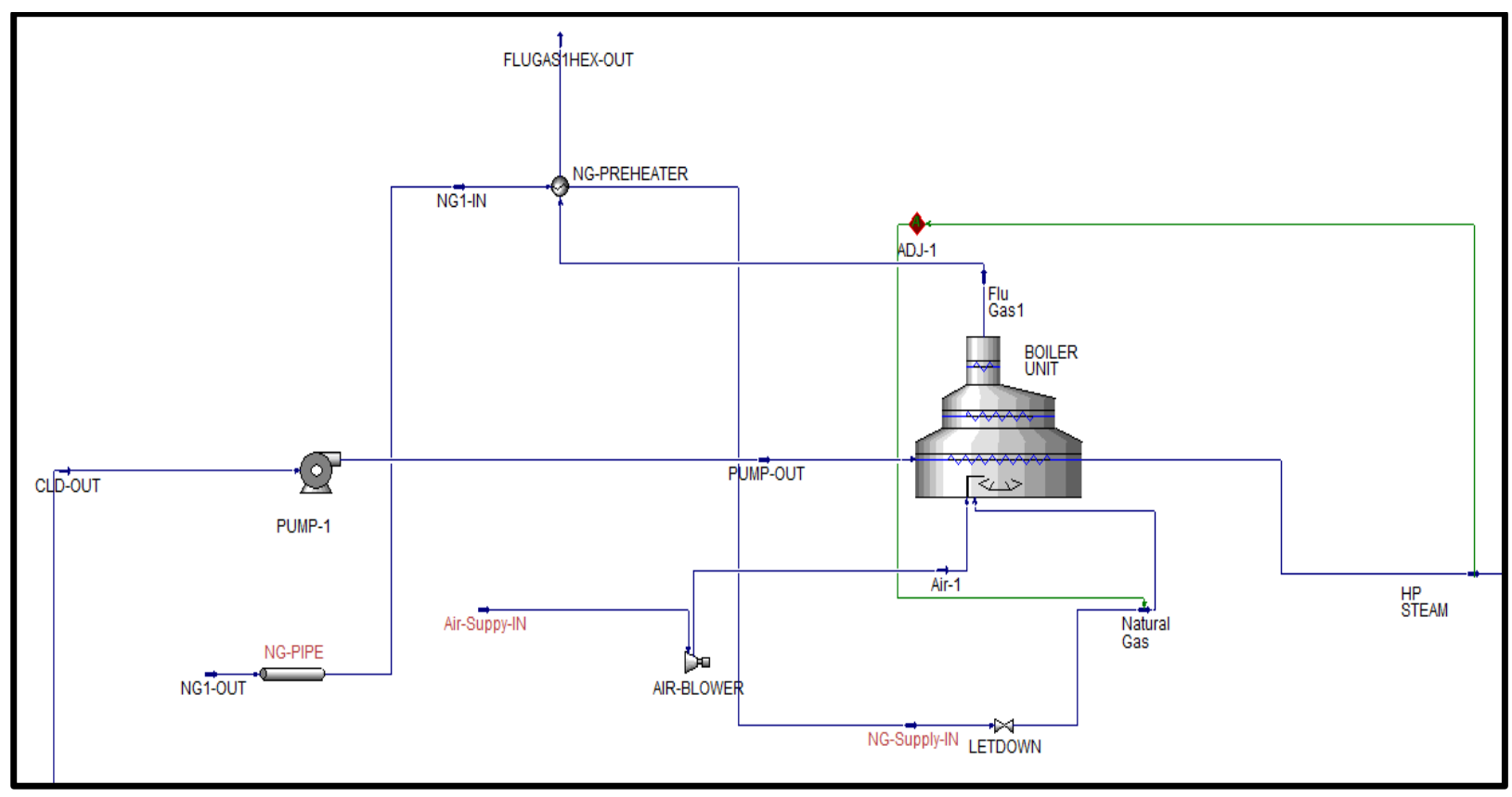

Figure 4.4: Boiler unit and other combustion components simulated in HYSYS.

In Figure 4.4, fuel preheater (NG-PREHEATER) was used to preheat the natural gas to a desired temperature before combusted in the boiler and an air blower (AIR-BLOWER) was used to push air into the combustion chamber. Maintaining natural gas temperature at about $65^{\circ} \mathrm{C}$ ensures the combustion is complete.

As shown in Figure 4.4, inlet and outlets streams to the fired heater are:

- PUMP-OUT: geothermal-heat pump preheated water,

- HP-STEAM: saturated or superheated steam produced from combustion of natural gas in the fired heater,

- Natural Gas and Air-1 (fuel inlets): a mixture of air (dry air) and natural gas, and

- Flue Gas1: Fired heater flue gas exhaust.

The major assumptions and conditions used in fired heater simulation:

- Fired Heater: Firebox efficiency was fixed at $85 \%$ and the adjust logical operator in HYSYS was used to perform optimization at steady state in order to meet steam requirements at the distribution points. 
- Air-Fuel Mixture: The air component of the air-fuel mixture for the combustion of natural gas is assumed to be made up of nitrogen (79\%) and oxygen (21\%) molar mixture while natural gas is assumed to be a molar mixture of methane (95\%), ethane $(2.5 \%)$ and propane (2.5\%) [49]. Dry air at $25^{\circ} \mathrm{C}$ is supplied at $10 \%$ excess of the stoichiometric requirement to ensure complete combustion of natural gas in firebox heater (AspenTech Database). Natural gas is supplied at industrial delivery pressure of 4.81 bar and a temperature of $15^{\circ} \mathrm{C}$ based on current WVU natural gas supply data obtained from WVU Facilities Management. The combustion of natural gas was assumed to be around atmospheric conditions and hence, the natural gas pressure was lowered by the valve (LETDOWN). Finally, a blower was used to push the air into the combustion burner and a fuel preheater was used to raise industrial natural gas supplied to meet temperature requirement of the firebox efficiency at $85 \%$.

- Air Blower: Air blower was used to compress and push air into the combustion chamber of the boiler unit at 0.8 bar

Air and natural gas inlet temperature and pressure for all the boiler units simulated in Aspen HYSYS are summarized in Table 4-1.

Table 4-1: Air and fuel inlet conditions for fired heater simulation in HYSYS.

\begin{tabular}{|c|c|c|}
\hline Fired Heater Input & Air & Natural Gas \\
\hline Temperature $\left({ }^{\circ} \mathrm{C}\right)$ & 58.88 & 63.52 \\
\hline Pressure (bar) & 0.80 & 0.80 \\
\hline
\end{tabular}

Fuel Preheater Unit: Based on the given inlet process conditions for the fired heater, the efficiency of the fired heater was about $80 \%$ whereas it was desired to provide a boiler with an efficiency as high as $85 \%$ to maximize fuel usage. In order to achieve this, the inlet fuel (natural gas) to the combustion chamber of the boiler was optimized using a fuel preheater. By varying the natural gas flow rate, adjust operator in HYSYS was used to achieve $85 \%$ efficiency in the fired heater to ensure that steam produced is at the required temperature and the flue gas temperature is not below $384^{\circ} \mathrm{C}$. The fuel preheater optimizes the boiler unit by channeling flue gas (Flue Gas1) 
exiting the boiler to the heat exchanger (NG-PREHEATER) where the flue gas was used to preheat the natural gas before it was sent to the boiler unit. STHE were used to obtain the required natural gas temperature inlet requirement to optimize the boiler. The pressure drop for HYSYS simulation of simple heat exchanger was assumed to be negligible.

\subsection{Distribution Piping System}

In geothermal district heating systems, the piping system as well as adequate insulation must be considered to minimize heat losses through pipelines. The distribution pipeline networks were used to transport steam produced from surface plant facility to the five distribution points in Scenario 1 or to the three distribution points in Scenario 2. To determine the total cost of pipeline distribution networks required to meet heating and cooling demand at WVU, the cost of the pipelines that transport steam to different campuses at WVU was estimated in Aspen ACCE.

\subsubsection{The major assumptions and conditions used in distribution pipeline simulation for the entire campus include:}

- The geothermal well location is near the HSC campus and the existing steam pipeline network was used for steam distribution. However, new pipelines are added to connect the geothermal well location at HSC to the existing MEA steam and condensate pipelines.

- One new steam pipeline

- HSCLOT81: transports steam from boiler outlet to the main MEA pipeline that connects to existing MEA pipeline at the Medical Center meter point.

- Two new condensate pipelines

- Cond-HSCLOT81PIPE-1: transports Evansdale and Downtown condensate return from main MEA line to the condensate receiver tank at the central plant site.

- Cond-HSCLOT81PIPE-2: transports HSC condensate return from main MEA line to the condensate receiver tank at the central plant site.

- Fuel pipelines were used to provide natural gas for combustion in the boiler

- NG-PIPE: transports natural gas from industrial delivery location to the boiler unit at the central plan site.

- Aspen ACCE was used to evaluate pipeline cost for: 
- Pipe material: carbon steel was used for the natural gas pipeline simulation while an alloy (carbon steel with chromium) was used to simulate steam and condensate pipelines in order to prevent pipeline corrosion [50], [51].

○ Pipe insulation type: polyurethane

○ Pipeline: fully buried

- Other assumptions include:

O No heat loss through the distribution pipelines $Q=0$

○ Pipe surface roughness: $0.00015 \mathrm{ft}$ (AspenTech default value)

○ Simulation to check for choke flow condition for all pipelines

○ Pipe schedule \#: 80

- Water loss between steam and condensate line: $10 \%$

\subsubsection{Pipeline Elevation}

Because the surface plant location is moved from MEA plant site to a new location at HSC the elevation changes along the main PRT route were considered for the five distribution points. Elevation change is defined as change in elevation between any two meter points. Google Maps was used to obtain the major elevation changes. The pipeline elevation changes along the Personal Rapid Transport (PRT) lines were input into the pipeline segments in HYSYS simulations. Table 4-2 shows the elevation changes and the corresponding pressure changes along the pipeline segments that were input into the HYSYS pipeline simulation.

Table 4-2: The elevation changes used in pipeline simulations in HYSYS.

\begin{tabular}{|c|c|c|c|}
\hline Map Location & Pipeline Name & $\begin{array}{c}\text { Elevation } \\
(\mathbf{f t})\end{array}$ & $\begin{array}{c}\text { Pressure } \\
\text { (bar) }\end{array}$ \\
\hline PRT-BEECHURST to PRT MEA & Cond-DTN-LFS2 & -111.00 & -3.32 \\
\hline PRT MEA to PRT Ag. SC & Cond-DTN-LFS & 124.00 & 3.71 \\
\hline PRT Ag. SC to PRT TOWERS & Cond-AGDTN & -26.00 & -0.78 \\
\hline PRT TOWERS to PRT MED CENTER & Cond-AGDTNTWRDTN & 99.00 & 2.96 \\
\hline PRT-MEDCENTER to CENTRAL PLANT & Cond-HSCLOT81PIPE-1 & 35.00 & 1.05 \\
\hline
\end{tabular}




\subsubsection{Steam distribution pipelines}

Figure 4.5 (Scenario 1) and Figure 4.6 (Scenario 2) show that the steam from the boiler outlet (Figure 4.4) was channeled into the first pipeline HSCLOT81, a new pipeline that connected steam produced at the centralized surface facility to existing MEA pipelines. At HSCLOT81 exit, the steam produced was split into two streams: one stream was diverted to the Medical Center meter point (MED-MTPT), the second stream, was sent to the main MEA steam pipeline at HSC and was transported to other campuses through a series of existing MEA pipelines. For Scenario 1, the series of existing MEA steam pipelines were: AGTWRDTN, TWR-PIPE, AG-DTN, AG-PIPE, DTN-LFSC, DTN-LFSC2, LFS-PIPE, DTN-PIPE while for Scenario 2 (Figure 4.6) the existing steam pipelines were: AGTWR, TWR-PIPE, AG-MEA, AG-PIPE.

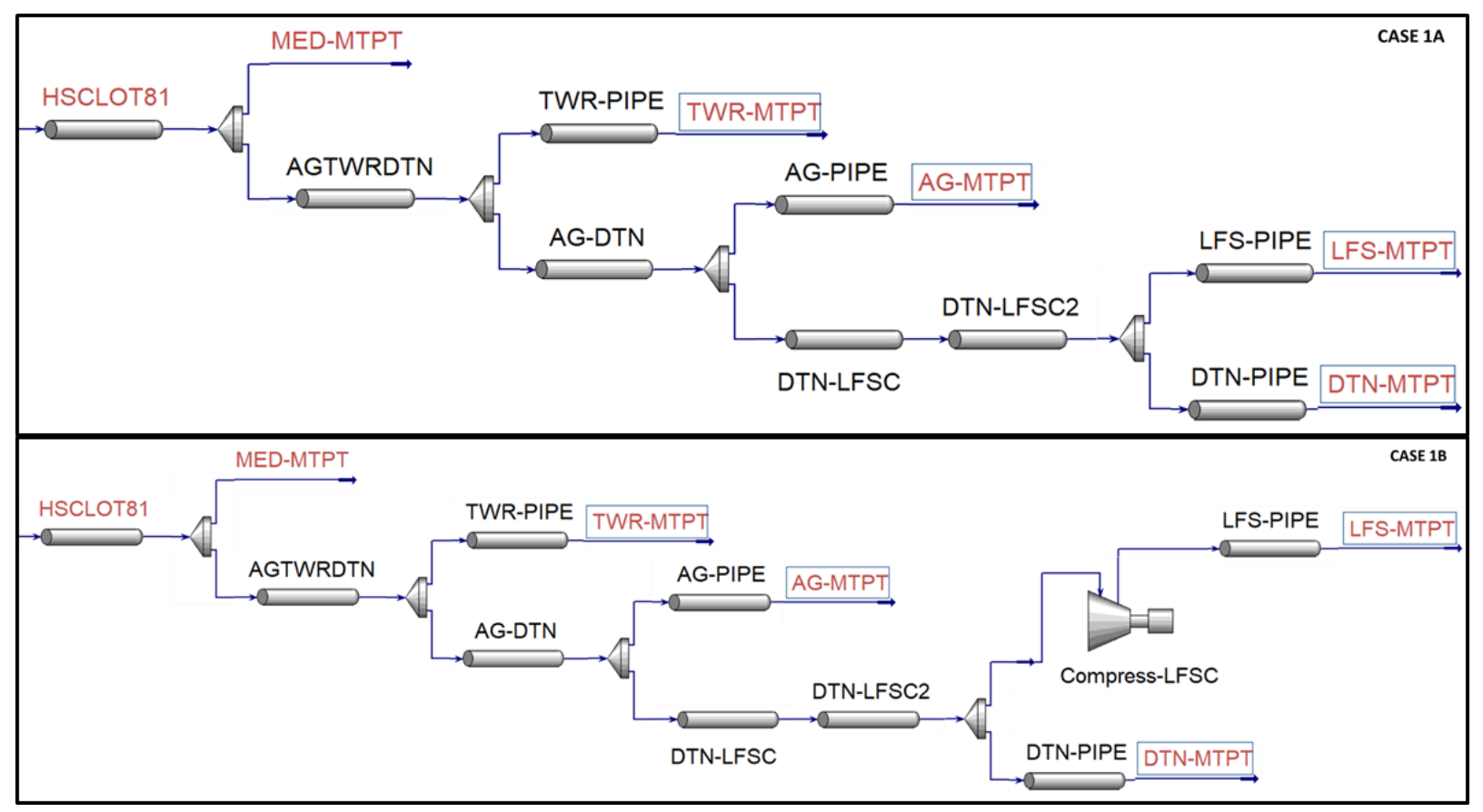

Figure 4.5: The schematic of the steam line simulated for Scenario 1 (Case $1 A$ \& Case 1B) pipeline distribution system. 


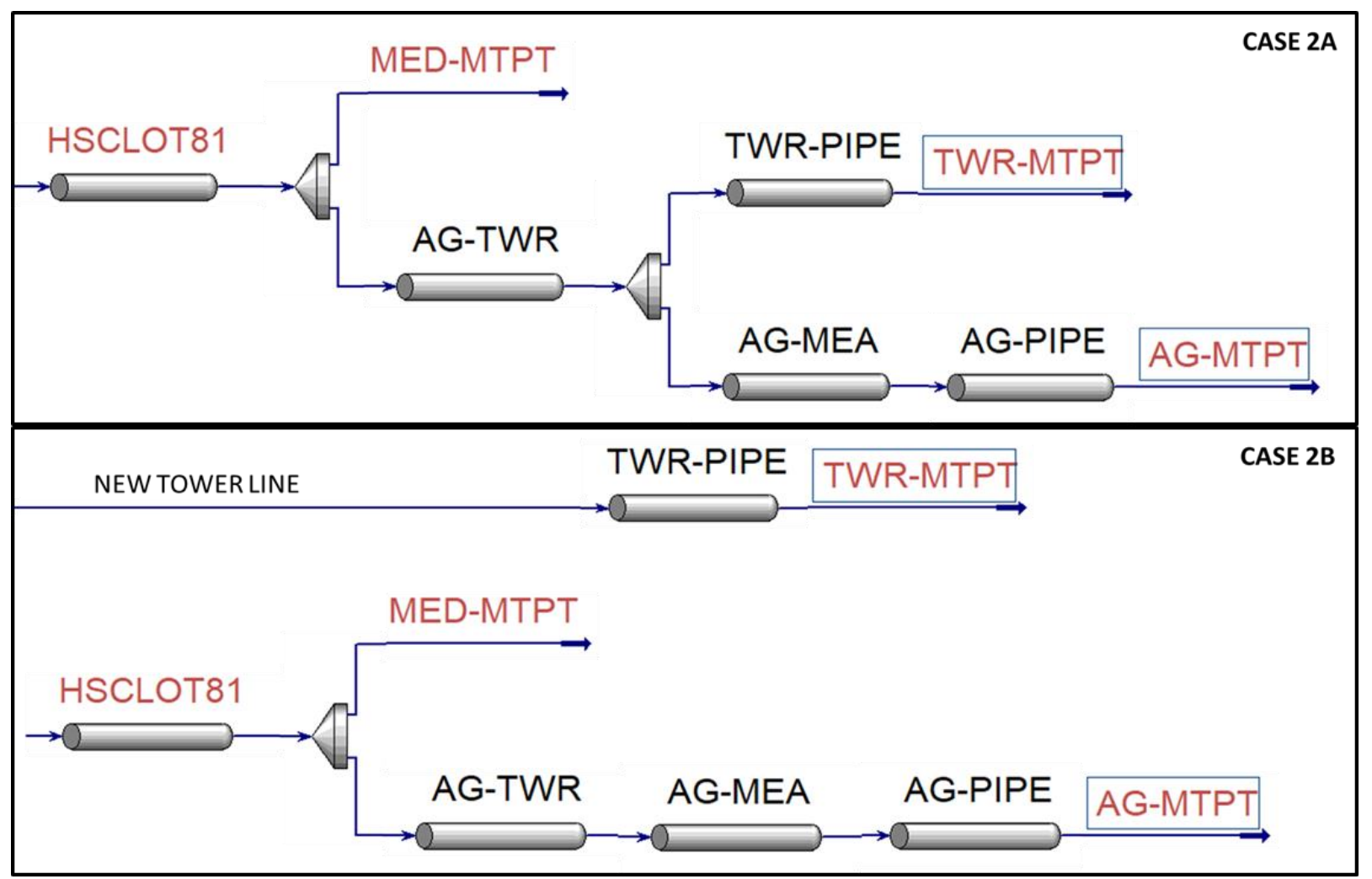

Figure 4.6: The schematic of steam line simulated for Scenario 2 (Case $2 A \&$ Case 2B) pipeline distribution system.

\subsubsection{Condensate return pipelines}

The pressures of the returning condensate at the distribution points are not known. However, WVU Facilities Management provided an estimated value of about 3.1 bar (30 psig) for the condensate pressure leaving an individual building. Assuming a pressure drop of $10 \mathrm{psig}$ between individual buildings and the meter point, the pressure of the returning condensate entering the meter point was estimated to be 2.4 bar (20 psig). The entire condensate line was simulated in HYSYS using 2.4 bar as the initial pressure at the meter point for the two scenarios. Also, the condensate flow rates were regulated such that the total water loss between the steam line supply and condensate return line was approximately 10\%; thus, $90 \%$ of the steam supplied was returned as condensate. The $10 \%$ makeup water accounted for water loss in the closed loop system.

Figure 4.7 and Figure 4.8 show the schematic of the condensate pipeline distribution system at WVU. For Scenario 1 as represented in Figure 4.7, the condensate return was transported from the 
five distribution points back to the centralized surface facility through existing MEA condensate pipelines (cond-LFS-PIPE, cond-DTN-PIPE, cond-DTN-LFSC2, cond-LFSC, cond-AG-PIPE, cond-AG-DTN, cond-TWR-PIPE, cond-AGTWRDTN). Similarly, for Scenario 2 (Figure 4.8) the condensate return was transported from the three distribution points back to the centralized surface facility through existing MEA condensate pipelines (cond-AG-PIPE, cond-AG-DTN, cond-TWRPIPE, cond-AGDTWRDTN). At HSC, however, two new condensate pipelines were added: condHSCLOT81PIPE-1 and cond-HSCLOT81PIPE-2 for the two scenarios. In Scenario 1 and Scenario 2 , the condensate lines delivered their returning water to the heat production unit at $65.59^{\circ} \mathrm{C}$ and $65.58^{\circ} \mathrm{C}$, respectively. The two returning condensate streams were mixed with $10 \%$ makeup water at a temperature of $15^{\circ} \mathrm{C}$ at a flow rate of $1.52 \mathrm{~kg} / \mathrm{s}$ for Scenario 1 and at flow rate of $1.02 \mathrm{~kg} / \mathrm{s}$ for Scenario 2 before the returning condensate were discharged into the condensate receiver tank (Figure 4.1). The resulting condensate-makeup water mixture from condensate receiver tank at $48.79^{\circ} \mathrm{C}$ (Scenario 1) and $50.43^{\circ} \mathrm{C}$ (Scenario 2) was sent back to GEO-HEX to complete the closed loop configuration. The condensate tank was assumed to be uninsulated and the residence time for the condensate return inside the tank was assumed to be negligible.

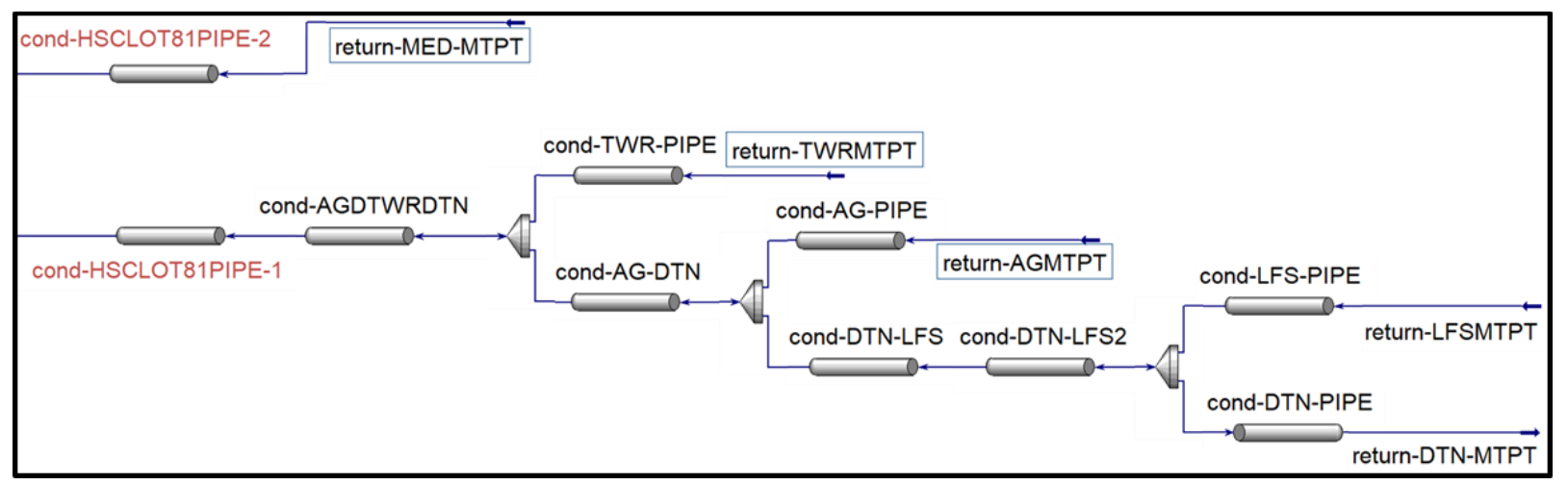

Figure 4.7: The schematic of the condensate line for Scenario 1 (Case $1 A$ \& Case 1B) pipeline distribution system. 


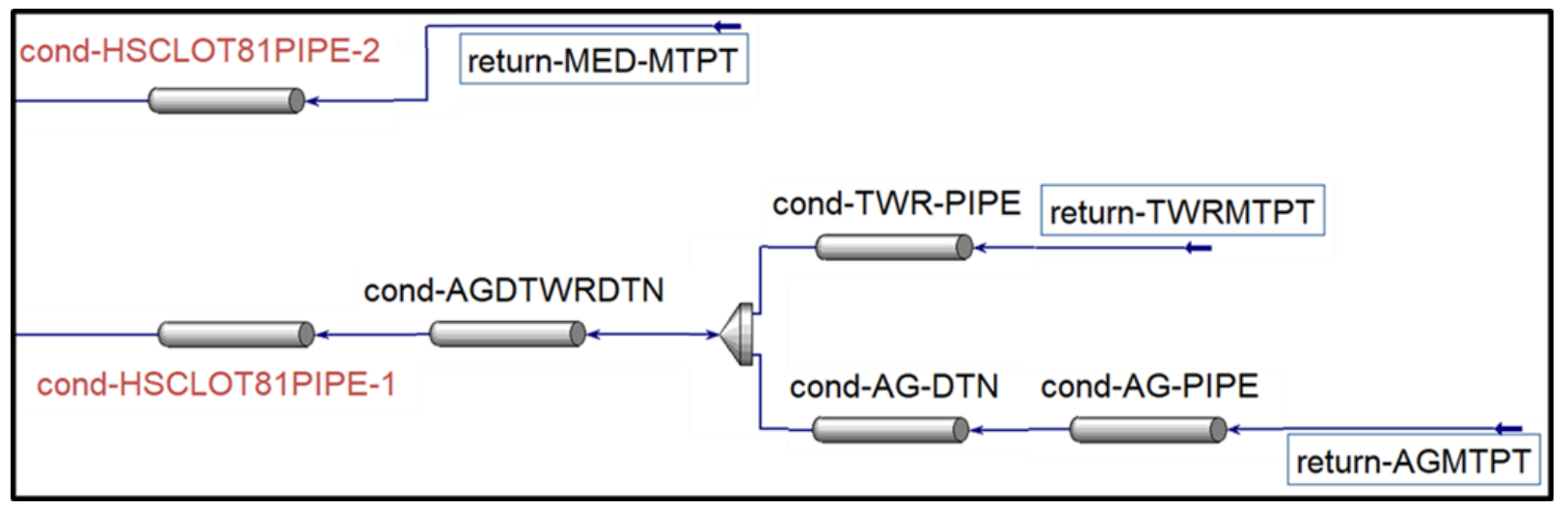

Figure 4.8: The schematic of the condensate line for Scenario 2 (Case $2 A \&$ Case 2B) pipeline distribution system.

\subsection{Heat Pump System}

\subsubsection{Heat Pump Principle}

A heat pump is a device used to transfer heat energy from a low-temperature heat source $T_{c}$ to a high-temperature heat sink $T_{h}$ [52]-[55]. When the operation of a heat pump is reversed, it works as a cooling or refrigeration system. The main difference between a heat pump and a refrigeration cycle is that the purpose of a heat pump is to deliver heat to a hot reservoir $\left(q_{h}\right)$ while the objective of a vapor-compression refrigeration cycle is to remove heat from a low-temperature space $\left(q_{c}\right)$.

The standard components of a heat pump system include condenser, compressor, evaporator, and an expansion valve as shown in Figure 4.9. The working fluid passes through all the components and forms a cycle/loop. The fluid that passes through the four components is called a refrigerant. The cycle begins with the evaporator. In Figure 4.9, the working fluid inside the evaporator evaporates by extracting heat from a low-temperature heat source. The compressor increases the pressure of the working fluid before it is condensed at high temperature and pressure inside the condenser during which condenser rejects the heat absorbed by the working fluid to a hightemperature heat sink. The condenser outlet stream is transported to the expansion valve to lower the pressure. The low temperature and pressure working fluid flows back to the evaporator to begin another cycle. 
Efficiency of a heat pump system is expressed by its Coefficient of Performance (COP) [52]. The $C O P$ is calculated as the ratio of the heat rejected by the condenser $\left(q_{c}\right)$ to the work input $(W)$ into the compressor using Eq. 1. The higher the COP, the higher the efficiency of a heat pump system,

$$
C O P_{\text {heat pump }}=\frac{q_{c}}{W}
$$

where $W$ is the electric power input into the compressor, and $q_{c}$ is the heat delivered or rejected by the condenser. The range of COP is usually between 4-6.

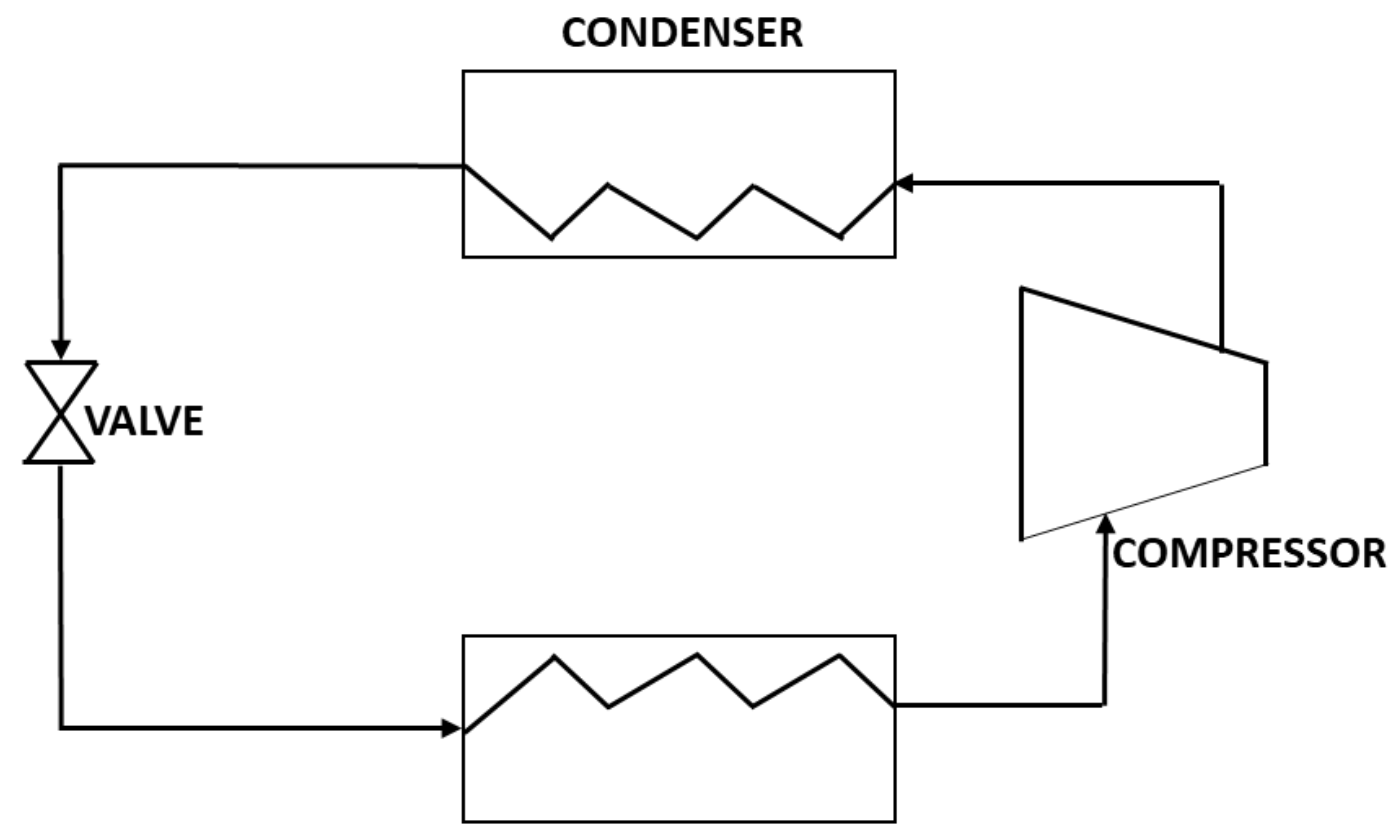

EVAPORATOR

Figure 4.9: A simplified diagram of a heat pump system [56].

\subsubsection{Selection of working fluid}

The design and performance of a heat pump depends on the working fluid employed for its operation while the efficiency of a heat pump also depends on the difference between heat source and heat sink temperature. Selection of a working fluid is an important factor as it affects the operation and efficiency of a heat pump system. Refrigerants such as carbon dioxide $\left(\mathrm{CO}_{2}\right)$, ammonia $\left(\mathrm{NH}_{3}\right)$, water, and hydrocarbons are the commonly used natural working fluid in the heat pump system operations. Basic simulations were performed for different working fluids and different heat pump configurations found in the literature. The properties of the working fluid and 
the heat pump simulated conditions were evaluated to come up with the best scenario for the WVU campus.

\section{Assumptions used in heat pump simulation}

- Compressor efficiency (adiabatic): $75 \%$ (AspenTech default value)

- There is no pressure drop across the heat exchanger

$\mathrm{CO}_{2}$ has a heat source temperature limit of $37^{\circ} \mathrm{C}$ for the inlet water whereas the heat source at WVU is around $65^{\circ} \mathrm{C}$. Ammonia $\left(\mathrm{NH}_{3}\right)$, on the other hand, has capacity for an inlet temperature range of $50-65^{\circ} \mathrm{C}$. Furthermore, $\mathrm{NH}_{3}$ is very efficient and gives a higher $\mathrm{COP}$ performance than $\mathrm{CO}_{2}$. Between the two different natural refrigerants simulated in HYSYS, $\mathrm{NH}_{3}$ was chosen as it operates within the temperature limit ranges suitable for the heat pump system requirements at WVU and could provide the desired higher temperature $\left(90^{\circ} \mathrm{C}\right)$ with better $\mathrm{COP}$. However, $\mathrm{NH}_{3}$ is toxic and safety measures must be put in place to avoid $\mathrm{NH}_{3}$ leakage and to prevent a potential performance problem due to refrigerant leakages. 


\section{Objective 3: Results and Discussion}

After description of setup for the Aspen EDR, Aspen ACCE and surface plant simulations in HYSYS, in chapter 4 , chapter 5 presents the results of the equipment and distribution pipeline simulations in HYSYS for Case 1A, Case 1B, Case 2A and Case 2B. In this chapter, the rigorous design of PHE and STHE were carried out in Aspen EDR in order to provide heat exchanger areas required to estimate the heat exchanger costs. Aspen ACCE was used to estimate equipment costs for geothermal PHE exchangers, STHE for natural gas preheaters, air blower, pre-insulated pipelines, hot water and condensate pumps, and condensate receiver tanks. Vendors' quotes are used to obtain the equipment costs for the proposed hybrid system boilers and heat pump.

\subsection{Geothermal Heat Exchanger Unit Results and Discussion}

HYSYS simulations results obtained from simple exchanger design are shown in Table 5-1Error! Reference source not found. for geothermal fluid and condensate fluid. This was followed by a rigorous design in Aspen EDR. Detailed design of the PHE in Aspen EDR provides the size of the centralized plate heat exchanger required for Scenario 1 and Scenario 2 heat loads. Following simulation of the PHE in HYSYS and subsequent rigorous design of the PHE configuration in Aspen EDR, the cost of the centralized plate heat exchanger was evaluated in Aspen ACCE. The resulting costs for Scenario 1 and Scenario 2 are described in the following paragraphs.

Table 5-1: The results of HYSYS simulation of geothermal plate heat exchanger (PHE).

\begin{tabular}{|c|c|c|c|c|c|c|c|c|}
\hline & \multicolumn{4}{|c|}{ Scenario 1 } & \multicolumn{4}{c|}{ Scenario 2 } \\
\hline & \multicolumn{2}{|c|}{ GEO (Hot Side) } & \multicolumn{2}{c|}{ COND (Cold Side) } & \multicolumn{2}{c|}{ GEO (Hot Side) } & \multicolumn{2}{c|}{ COND (Cold Side) } \\
\cline { 2 - 9 } & IN & OUT & IN & OUT & IN & OUT & IN & OUT \\
\hline $\begin{array}{c}\text { Mass flow rate } \\
(\mathrm{kg} / \mathrm{s})\end{array}$ & 15.20 & 15.20 & 15.20 & 15.20 & 10.20 & 10.20 & 10.20 & 10.20 \\
\hline $\begin{array}{c}\text { Temperature } \\
\left({ }^{\circ} \mathrm{C}\right)\end{array}$ & 80.00 & 53.83 & 48.79 & 75.00 & 80.00 & 55.46 & 50.43 & 75.00 \\
\hline $\begin{array}{c}\text { Pressure } \\
(\text { bar) }\end{array}$ & 1.00 & 1.00 & 1.00 & 1.00 & 1.00 & 1.00 & 1.00 & 1.00 \\
\hline
\end{tabular}




\subsubsection{Scenario 1 Heat Exchanger:}

Heat exchanger cost was determined for a centralized system where the entire geothermal district heating and cooling system has only one heat exchanger centralized at a location. Given a geothermal hot water flow rate of $15.2 \mathrm{~kg} / \mathrm{s}$ flowing counter-currently with a condensate water flow rate $(15.2 \mathrm{~kg} / \mathrm{s})$, a PHE area of $303.3 \mathrm{~m}^{2}$ is required to transfer about $1.67 \mathrm{MW}$ of heat from the geothermal fluid to condensate water. The overall heat transfer coefficient of about 1,103 $\mathrm{W} / \mathrm{m}^{2}-\mathrm{K}$ is within the acceptable ranges for plate heat exchanger [57]. Table 5-1 shows PHE geometry configuration obtained for scenario 1 from rigorous heat exchanger design together with given inlet and outlet temperatures for the geothermal fluid and condensate water. Table 5-2 shows the result of the rigorous PHE design in Aspen EDR. The area obtained from the rigorous design of PHE in EDR was input into Aspen ACCE to estimate cost of the heat exchanger as $\$ 221,600$.

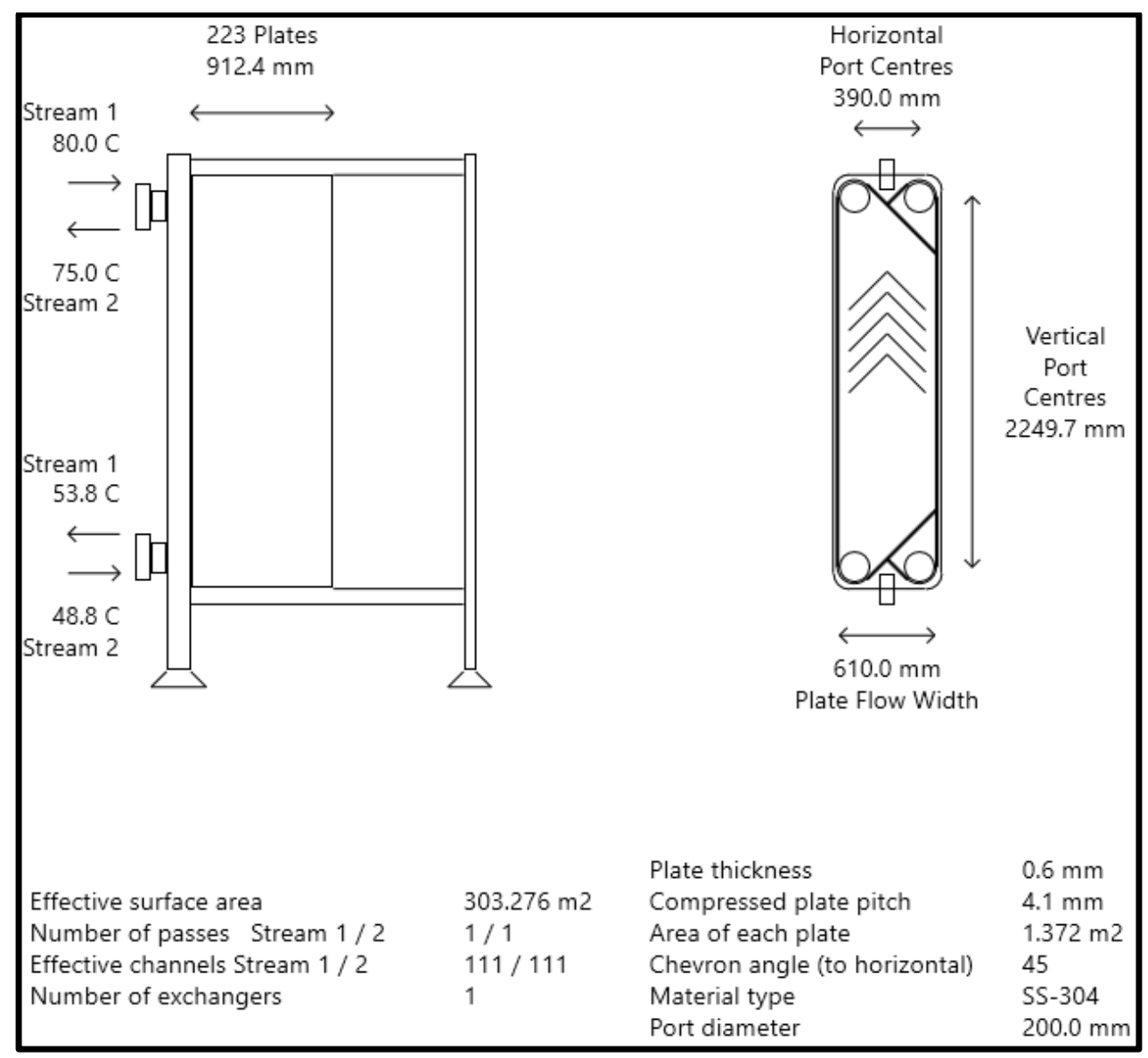

Figure 5.1: Details of the geometry obtained for Scenario 1 from rigorous heat exchanger design in EDR. 
Table 5-2: Results of rigorous design of plate heat exchanger (PHE) in EDR for Scenario 1.

\begin{tabular}{|c|c|}
\hline Parameter & Value \\
\hline PHE Area $\left(\mathrm{m}^{2}\right)$ & 303.30 \\
\hline Number of Plates & 223.00 \\
\hline Plate length $(\mathrm{mm})$ & $2,469.45$ \\
\hline Plate width $(\mathrm{mm})$ & 610.00 \\
\hline Overall heat transfer coefficient $\mathrm{U}\left(\mathrm{W} / \mathrm{m}^{2}-\mathrm{K}\right)$ & $1,103.00$ \\
\hline Heat Duty $(\mathrm{kW})$ & $1,674.40$ \\
\hline PHE Cost $(\$)$ & 221,600 \\
\hline
\end{tabular}

\subsubsection{Scenario 2 Heat Exchanger:}

In Scenario 2, for a geothermal hot water flow rate of $10.2 \mathrm{~kg} / \mathrm{s}$ flowing counter-currently with condensate water flow rate $(10.2 \mathrm{~kg} / \mathrm{s})$, a PHE area of $170.10 \mathrm{~m}^{2}$ is required to transfer about 1.05 MW of heat from the geothermal fluid to condensate water is about $\$ 172,400$. The overall heat transfer coefficient of about $1,103 \mathrm{~W} / \mathrm{m}^{2}-\mathrm{K}$ is within the acceptable ranges for plate heat exchanger[57]. Table 5-3 summarizes the result of the rigorous PHE design in Aspen EDR.

Table 5-3: Results of rigorous design of plate heat exchanger $(\mathrm{PHE})$ in EDR for Scenario 2.

\begin{tabular}{|c|c|}
\hline Parameter & Value \\
\hline PHE Area $\left(\mathrm{m}^{2}\right)$ & 170.10 \\
\hline Number of Plates & 243.00 \\
\hline Plate length $(\mathrm{mm})$ & $1,595.55$ \\
\hline Plate width $(\mathrm{mm})$ & 495.00 \\
\hline Overall heat transfer coefficient $\mathrm{U}\left(\mathrm{W} / \mathrm{m}^{2}-\mathrm{K}\right)$ & $1,470.20$ \\
\hline Heat Duty $(\mathrm{kW})$ & $1,053.20$ \\
\hline PHE Cost $(\$)$ & 172,400 \\
\hline
\end{tabular}


Figure 5.2 below summarizes Scenario 2 PHE geometry obtained from rigorous heat exchanger design together with given inlet and outlet temperatures for the geothermal fluid and condensate water.

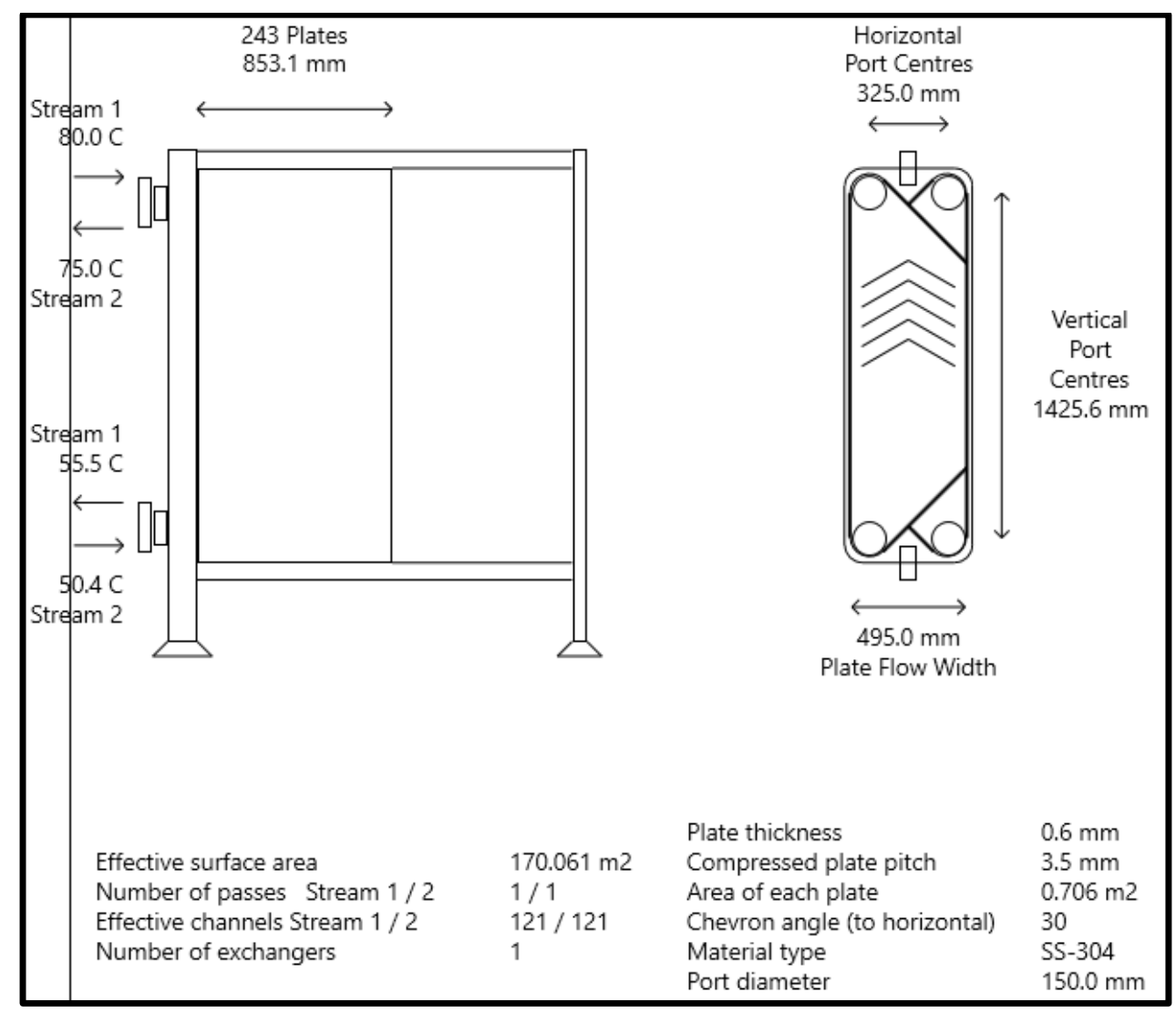

Figure 5.2: Details of the geometry obtained for Scenario 2 from rigorous heat exchanger design in EDR.

\subsection{Geothermal Contribution to the Heating and Cooling System at WVU Results and Discussion}

\subsubsection{Scenario 1 Geothermal Contribution}

Scenario 1 which supply the entire campus steam was further subdivided into two design schemesCase 1A and 1B. Case 1A, a boiler (Q $\mathbf{Q}$ вогеr1) provides high pressure steam at 18.25 bar and $260^{\circ} \mathrm{C}$ to the main distribution center while depending on the monthly steam demand, the heat exchanger extracted the required heat from the geofluid $\left(Q_{G E O}\right)$ flowing at a rate of $15.2 \mathrm{~kg} / \mathrm{s}$ and for all 12 months the secondary fluid temperature is preheated by $26.21^{\circ} \mathrm{C}$ (from $48.79^{\circ} \mathrm{C}$ to $75^{\circ} \mathrm{C}$ ). 
The geothermal contribution to the proposed hybrid GDHC system was calculated for two instances: (1) for a hybrid system without heat pump and (2) for a hybrid system with heat pump as shown in Equation 5.1 and Equation 5.2.

For the two instances considered, the geothermal contributions to the district heating and cooling at WVU are calculated as follows:

$$
\begin{aligned}
& \% G E O_{O N L Y}=\frac{Q_{G E O}}{Q_{G E O}+Q_{B O I L E R}} \\
& \% G E O_{H P}=\frac{Q_{G E O}}{Q_{G E O}+Q_{B O I L E R}+Q_{H E A T P U M P}}
\end{aligned}
$$

where $\% G E O_{O N L Y}$ is the geothermal contribution to the hybrid GDHC system and \%GEOHP is the geothermal contributions to the final improved hybrid system. The terms $Q_{G E O}, Q_{B O I L E R}$, and $Q_{\text {HEATPUMP }}$ are the amount of heat contributed to the proposed hybrid GDHC system at WVU by the geothermal, natural gas boiler and heat pump respectively.

Table 5-4 and Table 5.5 represent the hybrid geothermal contribution results for Case 1A without heat pump and with heat pump system, respectively. Here, the reservoir returning temperature $\left(T_{h}\right.$, out) was varied with the monthly secondary fluid flow rate (steam demand) and the amount of heat extracted by the geothermal and heat pump are determined for the 12 month period. The monthly geothermal contribution to the campus heating and cooling system without heat pump is about $2.30 \%$ and about $4.10 \%$ with heat pump. Heat pump alone thus contributes about $1.80 \%$ to the improved Case 1A. The heat pump enhanced Case 1A geothermal contribution by extracting additional heat from the condensate return and thereby, lowering geothermal re-injection temperature.

Table 5-4: Results for Case 1A simulated in HYSYS for geothermal contribution to a hybrid geothermal system without heat pump (\%GEO) to produce superheated steam at 18.25 bar and $260^{\circ} \mathrm{C}$ using

\begin{tabular}{|c|c|c|c|c|c|}
\hline Month & $\begin{array}{l}m_{\text {CLD }} \\
(\mathrm{kg} / \mathrm{s})\end{array}$ & $\begin{array}{l}\mathbf{T}_{\mathrm{h}, \text { out }} \\
\left({ }^{\circ} \mathbf{C}\right)\end{array}$ & $\begin{array}{c}\mathbf{Q}_{\mathrm{GEO}} \\
(\mathrm{MJ} / \mathrm{s})\end{array}$ & $\begin{array}{c}\text { QBOILER1 } \\
\text { (MJ/s) }\end{array}$ & $\%$ GEO ONLY \\
\hline
\end{tabular}
geothermal fluid flow rate of $15.2 \mathrm{~kg} / \mathrm{s}$ and varying monthly steam flow rate. 


\begin{tabular}{|c|c|c|c|c|c|}
\hline Oct. & 9.65 & 70.87 & 0.60 & 25.61 & 2.30 \\
\hline Nov. & 11.61 & 69.01 & 0.73 & 30.81 & 2.30 \\
\hline Dec. & 13.28 & 67.42 & 0.83 & 35.24 & 2.30 \\
\hline Jan. & 15.10 & 65.70 & 0.94 & 40.06 & 2.30 \\
\hline Feb. & 15.07 & 65.72 & 0.94 & 39.98 & 2.30 \\
\hline Mar. & 12.11 & 68.53 & 0.76 & 32.13 & 2.30 \\
\hline April & 9.11 & 71.38 & 0.57 & 24.17 & 2.30 \\
\hline May & 6.95 & 73.42 & 0.43 & 18.44 & 2.30 \\
\hline June & 6.61 & 73.75 & 0.41 & 17.54 & 2.30 \\
\hline July & 6.38 & 73.96 & 0.40 & 16.93 & 2.30 \\
\hline Aug. & 6.29 & 74.05 & 0.39 & 16.69 & 2.30 \\
\hline Sep. & 6.67 & 73.69 & 0.42 & 17.70 & 2.30 \\
\hline
\end{tabular}

Table 5-5: Results for Case 1A simulated in HYSYS for geothermal contribution to the improved hybrid geothermal system using heat pump (\%GEO $\left.{ }_{H P}\right)$ to produce superheated steam at 18.25 bar and $260^{\circ} \mathrm{C}$ using geothermal fluid flow rate of $15.2 \mathrm{~kg} / \mathrm{s}$ and varying monthly steam flow rate.

\begin{tabular}{|c|c|c|c|c|c|c|}
\hline Month & $\begin{array}{c}\mathbf{m}_{\mathbf{C L D}} \\
(\mathbf{k g} / \mathbf{s})\end{array}$ & $\begin{array}{c}\mathbf{T}_{\mathbf{h}, \mathbf{o u t}} \\
\left({ }^{\circ} \mathbf{C}\right)\end{array}$ & $\begin{array}{c}\mathbf{Q}_{\text {GeO }} \\
(\mathbf{M J} / \mathbf{s})\end{array}$ & $\begin{array}{c}\mathbf{Q}_{\text {воILER1 }} \\
(\mathbf{M J} / \mathbf{s})\end{array}$ & $\begin{array}{c}\mathbf{Q}_{\text {HEATPUMP }} \\
(\mathbf{M J} / \mathbf{s})\end{array}$ & \% GEOHP \\
\hline Oct. & 9.65 & 63.40 & 1.09 & 24.97 & 0.63 & 4.10 \\
\hline Nov. & 11.61 & 60.02 & 1.32 & 30.05 & 0.76 & 4.10 \\
\hline Dec. & 13.28 & 57.14 & 1.51 & 34.37 & 0.87 & 4.10 \\
\hline Jan. & 15.10 & 54.00 & 1.71 & 39.08 & 0.99 & 4.10 \\
\hline Feb. & 15.07 & 54.05 & 1.71 & 39.00 & 0.99 & 4.10 \\
\hline Mar. & 12.11 & 59.16 & 1.38 & 31.34 & 0.79 & 4.10 \\
\hline April & 9.11 & 64.34 & 1.03 & 23.58 & 0.60 & 4.10 \\
\hline May & 6.95 & 68.06 & 0.79 & 17.99 & 0.45 & 4.10 \\
\hline June & 6.61 & 68.64 & 0.75 & 17.08 & 0.43 & 4.10 \\
\hline July & 6.38 & 69.04 & 0.72 & 16.51 & 0.42 & 4.10 \\
\hline Aug. & 6.29 & 69.19 & 0.71 & 16.28 & 0.41 & 4.10 \\
\hline Sep. & 6.67 & 68.54 & 0.76 & 17.26 & 0.44 & 4.10 \\
\hline
\end{tabular}

Case 1B, on the other hand, has one boiler ( $\left.\boldsymbol{Q}_{\boldsymbol{B} \text { oILERI }}\right)$ where the condensate preheated by geothermal fluid was further heated to superheated steam at 14.5 bar by boiler $\left(\boldsymbol{Q}_{\boldsymbol{B} \text { BILERI }}\right)$ to supply 
superheated steam at these conditions directly to Health sciences (Medical Center), Evansdale and Downtown campuses. While at Downtown, the stream to Life Sciences distribution point was further compressed by a compressor to 18.25 bar for Life Sciences meter point. Based on geothermal flow rate of $15.2 \mathrm{~kg} / \mathrm{s}$ and preheating secondary fluid by $26.21^{\circ} \mathrm{C}$ (from $48.79^{\circ} \mathrm{C}$ to $75^{\circ} \mathrm{C}$ ), geothermal fluid contributes about $2.40 \%$ to the hybrid heating and cooling system as shown in Table 5.6. After improvement of the hybrid system by the heat pump, Case 1B geothermal contribution increases from $2.40 \%$ to about $4.39 \%$ as shown in Table 5.7 .

Table 5-6: Results for Case $1 B$ simulated in HYSYS for geothermal contribution to a hybrid geothermal system without heat pump (\%GEO) to produce superheated steam at 14.25 bar and $200^{\circ} \mathrm{C}$ for MedCenter, Towers, Evansdale, and Downtown meter points, and the compressor producing superheated steam at 18.25 bar and $260^{\circ} \mathrm{C}$ for Life Sciences meter point using geothermal fluid flow rate of $15.2 \mathrm{~kg} / \mathrm{s}$.

\begin{tabular}{|c|c|c|c|c|c|c|}
\hline Month & $\mathbf{m}_{\mathbf{C L D}}$ & $\begin{array}{c}\mathbf{T}_{\mathbf{h}, \mathbf{o u t}} \\
(\mathbf{k g} / \mathbf{s})\end{array}$ & $\begin{array}{c}\mathbf{Q}_{\text {GEO }} \\
(\mathbf{M})\end{array}$ & $\begin{array}{c}\mathbf{Q}_{\text {воILER }} \\
(\mathbf{M J} / \mathbf{s})\end{array}$ & $\begin{array}{c}\text { QсOмP } \\
(\mathbf{M J} / \mathbf{s})\end{array}$ & \% GEO ONLY \\
\hline Oct. & 9.65 & 70.87 & 0.60 & 24.49 & 0.03 & 2.40 \\
\hline Nov. & 11.61 & 69.01 & 0.73 & 29.46 & 0.05 & 2.40 \\
\hline Dec. & 13.28 & 67.42 & 0.83 & 33.70 & 0.06 & 2.40 \\
\hline Jan. & 15.10 & 65.7 & 0.94 & 38.32 & 0.09 & 2.40 \\
\hline Feb. & 15.07 & 65.72 & 0.94 & 38.32 & 0.09 & 2.40 \\
\hline Mar. & 12.11 & 68.53 & 0.76 & 30.73 & 0.05 & 2.40 \\
\hline April & 9.11 & 71.38 & 0.57 & 23.12 & 0.03 & 2.40 \\
\hline May & 6.95 & 73.42 & 0.43 & 17.64 & 0.02 & 2.40 \\
\hline June & 6.61 & 73.75 & 0.41 & 16.77 & 0.02 & 2.40 \\
\hline July & 6.38 & 73.96 & 0.40 & 16.19 & 0.02 & 2.40 \\
\hline Aug. & 6.29 & 74.05 & 0.39 & 15.96 & 0.02 & 2.40 \\
\hline Sep. & 6.67 & 73.69 & 0.42 & 16.93 & 0.02 & 2.40 \\
\hline
\end{tabular}

Table 5-7: Results for Case 1B simulated in HYSYS for geothermal contribution to the improved hybrid geothermal system using heat pump (\%GEO $\left.O_{H P}\right)$ to produce superheated steam at 14.25 bar and $200^{\circ} \mathrm{C}$ for Med-Center, Towers, Evansdale, and Downtown meter points, and the compressor producing superheated steam at 18.25 bar and $260^{\circ} \mathrm{C}$ for Life Sciences meter point using geothermal fluid flow rate of $15.2 \mathrm{~kg} / \mathrm{s}$. 


\begin{tabular}{|c|c|c|c|c|c|c|c|}
\hline Month & $\begin{array}{c}\mathbf{m}_{\text {CLD }} \\
(\mathbf{k g} / \mathbf{s})\end{array}$ & $\begin{array}{c}\mathbf{T}_{\mathbf{h}, \mathbf{o u t}} \\
\left({ }^{\circ} \mathbf{C}\right)\end{array}$ & $\begin{array}{c}\mathbf{Q}_{\text {GEO }} \\
(\mathbf{M J} / \mathbf{s})\end{array}$ & $\begin{array}{c}\mathbf{Q}_{\text {BOILER1 }} \\
(\mathbf{M J} / \mathbf{s})\end{array}$ & $\begin{array}{c}\mathbf{Q}_{\text {COMP }} \\
(\mathbf{M J} / \mathbf{s})\end{array}$ & $\begin{array}{c}\mathbf{Q}_{\text {HEATPUMP }} \\
(\mathbf{M J} / \mathbf{s})\end{array}$ & $\begin{array}{c}\text { \% } \\
\mathbf{G E O}_{\text {HP }}\end{array}$ \\
\hline Oct. & 9.65 & 63.4 & 1.1 & 23.86 & 0.03 & 0.63 & 4.28 \\
\hline Nov. & 11.61 & 60.02 & 1.32 & 28.7 & 0.05 & 0.63 & 4.38 \\
\hline Dec. & 13.28 & 57.14 & 1.51 & 32.83 & 0.06 & 0.63 & 4.38 \\
\hline Jan. & 15.1 & 54 & 1.71 & 37.33 & 0.09 & 0.63 & 4.38 \\
\hline Feb. & 15.07 & 54.05 & 1.71 & 37.26 & 0.09 & 0.63 & 4.38 \\
\hline Mar. & 12.11 & 59.16 & 1.38 & 29.94 & 0.05 & 0.63 & 4.38 \\
\hline April & 9.11 & 64.34 & 1.03 & 22.52 & 0.03 & 0.63 & 4.38 \\
\hline May & 6.95 & 68.06 & 0.79 & 17.18 & 0.02 & 0.63 & 4.39 \\
\hline June & 6.61 & 68.64 & 0.75 & 16.34 & 0.02 & 0.63 & 4.39 \\
\hline July & 6.38 & 69.04 & 0.72 & 15.77 & 0.02 & 0.63 & 4.39 \\
\hline Aug & 6.29 & 69.19 & 0.71 & 15.55 & 0.02 & 0.63 & 4.39 \\
\hline Sep. & 6.67 & 68.54 & 0.76 & 16.49 & 0.02 & 0.63 & 4.39 \\
\hline
\end{tabular}

\subsubsection{Scenario 2 Geothermal Contribution}

Similar to Scenario 1, Scenario 2 has two design schemes (Case 2A and 2B) and supply steam to only Health Sciences and Evansdale and Towers meter points. In Case 2A, a centralized system with a boiler $\left(\boldsymbol{Q}_{\text {BOILERI }}\right)$ supplies saturated steam at 12.5 bar to the three distribution points Towers, Evansdale and Medical Center meter points. For a geothermal flow rate of $10.2 \mathrm{~kg} / \mathrm{s}$ and preheating secondary fluid temperature by $30.5^{\circ} \mathrm{C}$ (from $50.43^{\circ} \mathrm{C}$ to $75^{\circ} \mathrm{C}$ ), geothermal contributes $2.42 \%$ to the hybrid system as represented in Table 5-8 where the amount of heat extracted from geothermal fluid $\left(Q_{G E O}\right)$ and the reservoir returning temperature depend on the monthly steam demand. Heat pump provides additional heat by raising preheated water temperature from $75^{\circ} \mathrm{C}$ to $90^{\circ} \mathrm{C}$. As shown in Table 5-9, when Case 2A system was improved by the heat pump, geothermal contributes a total of $4.05 \%$ to the hybrid system.

Table 5-8: Results for Case 2A simulated in HYSYS for geothermal contribution to a hybrid geothermal system without heat pump (\%GEO) to produce superheated steam at 12.5 bar using geothermal fluid flow rate of $10.2 \mathrm{~kg} / \mathrm{s}$.

\begin{tabular}{|c|c|c|c|c|c|}
\hline Month & $\begin{array}{c}\mathbf{m}_{\text {CLD }} \\
(\mathbf{k g} / \mathbf{s})\end{array}$ & $\begin{array}{c}\mathbf{T}_{\mathbf{h}, \mathbf{o u t}} \\
\left({ }^{\circ} \mathbf{C}\right)\end{array}$ & $\begin{array}{c}\mathbf{Q}_{\text {GEO }} \\
(\mathbf{M J} / \mathbf{s})\end{array}$ & $\begin{array}{c}\mathbf{Q}_{\text {BOILER1 }} \\
(\mathbf{M J} / \mathbf{s})\end{array}$ & \% GEO ONLY \\
\hline Oct. & 6.85 & 70.33 & 0.43 & 17.29 & 2.42 \\
\hline
\end{tabular}




\begin{tabular}{|c|c|c|c|c|c|}
\hline Nov. & 7.83 & 68.94 & 0.49 & 19.76 & 2.42 \\
\hline Dec. & 8.95 & 67.35 & 0.56 & 22.59 & 2.42 \\
\hline Jan. & 10.05 & 65.79 & 0.63 & 25.36 & 2.42 \\
\hline Feb. & 10.02 & 65.84 & 0.63 & 25.36 & 2.42 \\
\hline Mar. & 8.34 & 68.22 & 0.52 & 21.05 & 2.42 \\
\hline April & 6.49 & 70.83 & 0.41 & 16.38 & 2.42 \\
\hline May & 5.08 & 72.83 & 0.32 & 12.82 & 2.42 \\
\hline June & 4.81 & 73.21 & 0.30 & 12.14 & 2.42 \\
\hline July & 4.84 & 73.17 & 0.30 & 12.22 & 2.42 \\
\hline Aug. & 4.78 & 73.25 & 0.30 & 12.06 & 2.42 \\
\hline Sept. & 4.91 & 73.07 & 0.31 & 12.39 & 2.42 \\
\hline
\end{tabular}

Table 5-9: Results for Case 2A simulated in HYSYS for geothermal contribution to the improved hybrid geothermal system using heat pump $\left(\% \mathrm{GEO}_{H P}\right)$ to produce superheated steam at 12.5 bar using geothermal fluid flow rate of $10.2 \mathrm{~kg} / \mathrm{s}$.

\begin{tabular}{|c|c|c|c|c|c|c|}
\hline Month & $\begin{array}{c}\mathbf{m}_{\text {CLD }} \\
(\mathbf{k g} / \mathbf{s})\end{array}$ & $\begin{array}{c}\mathbf{T}_{\mathbf{h , o u t}} \\
\left({ }^{\circ} \mathbf{C}\right)\end{array}$ & $\begin{array}{c}\mathbf{Q}_{\text {GEO }} \\
(\mathbf{M J} / \mathbf{s})\end{array}$ & $\begin{array}{c}\mathbf{Q}_{\text {вOILER1 }} \\
(\mathbf{M J} / \mathbf{s})\end{array}$ & $\begin{array}{c}\mathbf{Q}_{\text {HEATPUMP }} \\
(\mathbf{M J} / \mathbf{s})\end{array}$ & \% GEO \\
\hline Oct. & 6.85 & 63.54 & 0.73 & 16.84 & 0.45 & 4.05 \\
\hline Nov. & 7.83 & 61.18 & 0.83 & 19.25 & 0.51 & 4.05 \\
\hline Dec. & 8.95 & 58.48 & 0.95 & 22.00 & 0.59 & 4.05 \\
\hline Jan. & 10.05 & 55.83 & 1.07 & 24.71 & 0.66 & 4.05 \\
\hline Feb. & 10.02 & 55.90 & 1.07 & 24.63 & 0.66 & 4.05 \\
\hline Mar. & 8.34 & 59.95 & 0.89 & 20.50 & 0.55 & 4.05 \\
\hline April & 6.49 & 64.41 & 0.69 & 15.95 & 0.42 & 4.05 \\
\hline May & 5.08 & 67.80 & 0.54 & 12.49 & 0.33 & 4.05 \\
\hline June & 4.81 & 68.45 & 0.51 & 11.82 & 0.31 & 4.05 \\
\hline July & 4.84 & 68.38 & 0.52 & 11.90 & 0.32 & 4.05 \\
\hline Aug. & 4.78 & 68.52 & 0.51 & 11.75 & 0.31 & 4.05 \\
\hline Sep. & 4.91 & 68.21 & 0.52 & 12.07 & 0.32 & 4.05 \\
\hline
\end{tabular}

Case 2B also has a centralized geothermal heat exchanger but with two boilers. One of the boilers $\left(\boldsymbol{Q}_{\boldsymbol{B} \text { oILERI }}\right)$ produces saturated steam at 12.5 bar for Evansdale and Medical Center meter points and the second boiler $\left(\boldsymbol{Q}_{\boldsymbol{B} \text { oILERI }}\right)$ produces saturated steam at 2.75 bar for Towers meter point because 
Towers requires steam supply at a very low-pressure condition. Based on geothermal flow rate of $10.2 \mathrm{~kg} / \mathrm{s}$ and preheating secondary fluid by from $48.79^{\circ} \mathrm{C}$ to $75^{\circ} \mathrm{C}\left(24.57^{\circ} \mathrm{C}\right)$, the geothermal contribution to the hybrid system is about $2.43 \%$ without the heat pump as in Table 5.10 and about $4.05 \%$ with heat pump system as shown in Table 5-11.

Table 5-10: Results for Case $2 B$ for geothermal contribution to a hybrid geothermal system without heat pump (\%GEO) with two boilers: one producing saturated steam at 12.5 bar for Evansdale and Medical Center meter points, and the second boiler producing low pressure steam at 2.75 bar for Towers using geothermal fluid flow rate of $10.2 \mathrm{~kg} / \mathrm{s}$.

\begin{tabular}{|c|c|c|c|c|c|c|}
\hline Month & $\begin{array}{l}m_{C L D} \\
(\mathrm{~kg} / \mathrm{s})\end{array}$ & $\begin{array}{l}\mathbf{T}_{\mathrm{h}, \text { out }} \\
\left({ }^{\circ} \mathbf{C}\right)\end{array}$ & $\begin{array}{c}\mathbf{Q}_{\mathrm{GEO}} \\
(\mathrm{MJ} / \mathrm{s})\end{array}$ & $\begin{array}{c}\text { QBOILER1 } \\
\text { (MJ/s) }\end{array}$ & $\begin{array}{c}\text { QBOILER2 } \\
\text { (MJ/s) }\end{array}$ & \% GEO ONLY \\
\hline Oct. & 6.85 & 70.33 & 0.43 & 16.03 & 1.23 & 2.43 \\
\hline Nov. & 7.83 & 68.94 & 0.49 & 18.32 & 1.41 & 2.43 \\
\hline Dec. & 8.95 & 67.35 & 0.56 & 20.94 & 1.61 & 2.43 \\
\hline Jan. & 10.05 & 65.80 & 0.63 & 23.52 & 1.81 & 2.43 \\
\hline Feb. & 10.02 & 65.84 & 0.63 & 23.45 & 1.80 & 2.43 \\
\hline Mar. & 8.34 & 68.20 & 0.52 & 19.52 & 1.50 & 2.43 \\
\hline April & 6.49 & 70.83 & 0.41 & 15.19 & 1.17 & 2.43 \\
\hline May & 5.08 & 72.83 & 0.32 & 11.89 & 0.91 & 2.43 \\
\hline June & 4.81 & 73.21 & 0.30 & 11.26 & 0.86 & 2.43 \\
\hline July & 4.84 & 73.17 & 0.30 & 11.33 & 0.87 & 2.43 \\
\hline Aug. & 4.78 & 73.25 & 0.30 & 11.19 & 0.86 & 2.43 \\
\hline Sep. & 4.91 & 73.07 & 0.31 & 11.49 & 0.88 & 2.43 \\
\hline
\end{tabular}

Table 5-11: Results for Case 2B for geothermal contribution to the improved hybrid geothermal system using heat pump (\%GEO $\left.{ }_{H P}\right)$ with two boilers: one producing saturated steam at 12.5 bar for Evansdale and Med-Center meter points, and the second boiler producing low pressure steam at 2.75 bar for Towers using geothermal fluid flow rate of $10.2 \mathrm{~kg} / \mathrm{s}$.

\begin{tabular}{|c|c|c|c|c|c|c|c|}
\hline Month & $\begin{array}{c}\mathbf{m}_{\text {CLD }} \\
(\mathbf{k g} / \mathbf{s})\end{array}$ & $\begin{array}{c}\mathbf{T}_{\mathbf{h}, \text { out }} \\
\left({ }^{\circ} \mathbf{C}\right)\end{array}$ & $\begin{array}{c}\mathbf{Q}_{\text {GeO }} \\
(\mathbf{M J} / \mathbf{s})\end{array}$ & $\begin{array}{c}\mathbf{Q}_{\text {BOILER1 }} \\
(\mathbf{M J} / \mathbf{s})\end{array}$ & $\begin{array}{c}\mathbf{Q}_{\text {BoILER2 }} \\
(\mathbf{M J} / \mathbf{s})\end{array}$ & $\begin{array}{c}\mathbf{Q}_{\text {HEATPUMP }} \\
(\mathbf{M J} / \mathbf{s})\end{array}$ & \% GEO \\
\hline Oct. & 6.85 & 63.57 & 0.73 & 15.62 & 1.20 & 0.45 & 4.05 \\
\hline Nov. & 7.83 & 61.22 & 0.83 & 17.85 & 1.37 & 0.51 & 4.05 \\
\hline
\end{tabular}




\begin{tabular}{|c|c|c|c|c|c|c|c|}
\hline Dec. & 8.95 & 58.52 & 0.95 & 20.40 & 1.57 & 0.59 & 4.05 \\
\hline Jan. & 10.05 & 55.88 & 1.07 & 22.91 & 1.76 & 0.66 & 4.05 \\
\hline Feb. & 10.02 & 55.95 & 1.06 & 22.84 & 1.75 & 0.66 & 4.05 \\
\hline Mar. & 8.34 & 55.99 & 0.89 & 19.01 & 1.46 & 0.55 & 4.05 \\
\hline April & 6.49 & 64.44 & 0.69 & 14.80 & 1.14 & 0.42 & 4.05 \\
\hline May & 5.08 & 67.83 & 0.54 & 11.58 & 0.89 & 0.33 & 4.05 \\
\hline June & 4.81 & 68.48 & 0.51 & 10.97 & 0.84 & 0.31 & 4.05 \\
\hline July & 4.84 & 68.40 & 0.51 & 11.03 & 0.85 & 0.32 & 4.05 \\
\hline Aug. & 4.78 & 68.55 & 0.51 & 10.90 & 0.84 & 0.31 & 4.05 \\
\hline Sep. & 4.91 & 68.24 & 0.52 & 11.19 & 0.86 & 0.32 & 4.05 \\
\hline
\end{tabular}

For the hybrid GDHC system, the secondary fluid flow rate is based on the monthly steam demand, all the cases evaluated show that geothermal contributions to the heating and cooling system at WVU campus is around $2 \%$ without the heat pump. Low geothermal percentage contribution to the monthly campus heat demand is due to considerably high latent heat for conversion of hot water to steam. However, the hybrid system performance was enhanced by the use of heat pump, geothermal contribution percent for Scenario 1 and Scenario 2 increased by about $1.80 \%$ and $1.99 \%$. The heat pump improved geothermal contribution by extracting additional heat from the condensate return and thereby, lowering geothermal re-injection temperature.

\subsection{Boiler Unit: Fired Heater Results and Discussion}

\subsubsection{Fired Heater Inlet Conditions:}

HYSYS simulation results of a fired heater for Scenario 1 (Case 1A and Case 1B) and Scenario 2 (Case 2A and Case 2B) are shown in Table 5-12 and Table 5-13.

Table 5-12: The data obtained from HYSYS simulation of natural gas fuel preheater for Scenario 1.

\begin{tabular}{|c|c|c|c|c|c|c|c|c|}
\hline Natural Gas Input & \multicolumn{3}{|c|}{ Case 1A } & \multicolumn{3}{c|}{ Case 1B } \\
\cline { 2 - 8 } & $\begin{array}{c}\text { Natural Gas } \\
\text { (Cold Side) }\end{array}$ & \multicolumn{2}{|c|}{$\begin{array}{c}\text { Flue Gas1 } \\
\text { (Hot Side) }\end{array}$} & \multicolumn{2}{c|}{$\begin{array}{c}\text { Natural Gas } \\
\text { (Cold Side) }\end{array}$} & \multicolumn{2}{c|}{$\begin{array}{c}\text { Flue Gas1 } \\
\text { (Hot Side) }\end{array}$} \\
\cline { 2 - 8 } & IN & OUT & IN & OUT & IN & OUT & IN & OUT \\
\hline $\begin{array}{c}\text { Temperature } \\
\left({ }^{\circ} \mathrm{C}\right)\end{array}$ & 14.73 & 65.00 & 384.12 & 379.36 & 14.75 & 65.00 & 384.07 & 379.32 \\
\hline
\end{tabular}




\begin{tabular}{|c|c|c|c|c|c|c|c|c|}
\hline $\begin{array}{c}\text { Pressure } \\
(\text { bar })\end{array}$ & 4.32 & 4.32 & 0.80 & 0.80 & 4.37 & 4.37 & 0.80 & 0.80 \\
\hline $\begin{array}{c}\text { Mass flow rate } \\
(\mathrm{kg} / \mathrm{s})\end{array}$ & 0.95 & 0.95 & 18.61 & 18.61 & 0.90 & 0.90 & 17.78 & 17.78 \\
\hline
\end{tabular}

Table 5-13: The data obtained from HYSYS simulation of natural gas fuel preheater for Scenario 2.

\begin{tabular}{|c|c|c|c|c|c|c|c|c|}
\hline \multirow{2}{*}{ Natural Gas Input } & \multicolumn{4}{|c|}{ Case 2A } & \multicolumn{4}{c|}{ Case 2B } \\
\cline { 2 - 9 } & $\begin{array}{c}\text { Natural Gas } \\
\text { (Cold Side) }\end{array}$ & \multicolumn{2}{|c|}{$\begin{array}{c}\text { Flue Gas1 } \\
\text { (Hot Side) }\end{array}$} & \multicolumn{2}{c|}{$\begin{array}{c}\text { Natural Gas } \\
\text { (Cold Side) }\end{array}$} & \multicolumn{2}{|c|}{$\begin{array}{c}\text { Flue Gas1 } \\
\text { (Hot Side) }\end{array}$} \\
\cline { 2 - 9 } & IN & OUT & IN & OUT & IN & OUT & IN & OUT \\
\hline $\begin{array}{c}\text { Temperature } \\
\left({ }^{\circ} \mathrm{C}\right)\end{array}$ & 14.90 & 65.00 & 383.98 & 379.24 & 14.90 & 65.00 & 383.98 & 379.24 \\
\hline $\begin{array}{c}\text { Pressure } \\
(\text { bar })\end{array}$ & 4.63 & 4.63 & 0.80 & 0.80 & 4.63 & 4.63 & 0.80 & 0.80 \\
\hline $\begin{array}{c}\text { Mass flow rate } \\
(\mathrm{kg} / \mathrm{s})\end{array}$ & 0.57 & 0.57 & 11.17 & 11.17 & 0.56 & 0.56 & 11.00 & 11.00 \\
\hline
\end{tabular}

\section{Scenario 1 Fired Heater:}

Table 5-14 shows that for Case 1A which supply superheated steam to the entire campus, about $0.95 \mathrm{~kg} / \mathrm{s}$ of natural gas is required to produce superheated steam at $\mathrm{T}=260^{\circ} \mathrm{C}$. Case $1 \mathrm{~B}$, on the other hand, requires about $0.90 \mathrm{~kg} / \mathrm{s}$ of natural gas to produce superheated steam at required temperature of $200^{\circ} \mathrm{C}$ steam conditions. The inlet hot water conditions and the outlet high-pressure steam conditions for the boiler (Boiler1) simulated for Case 1A and Case 1B as well as exiting flue gas (Flue Gas1) conditions for temperature, pressure, and flow rate are summarized in Table 5.14 below.

Table 5-14: Inlet hot water, flue gas and high pressure steam outlet conditions for the combustion of natural gas simulated in HYSYS fired heater for Case 1A and Case 1B obtained at a fixed boiler efficiency of $\eta=85 \%$, a fixed boiler hot water inlet temperature of $90^{\circ} \mathrm{C}$ for a given natural gas flow rate.

\begin{tabular}{|c|c|c|c|c|c|c|c|c|}
\hline \multirow{2}{*}{ Fired Heater } & \multicolumn{2}{|c|}{ Hot water inlet } & \multicolumn{2}{c|}{ HP-Steam } & \multicolumn{2}{c|}{ Natural Gas } & \multicolumn{2}{c|}{ Flue Gas1 } \\
\cline { 2 - 9 } & Case & Case & Case & Case & Case & Case & Case & Case \\
& 1A & 1B & 1A & 1B & 1A & 1B & 1A & 1B \\
\hline Temperature & 90.00 & 90.00 & 260 & 200 & 63.74 & 63.74 & 384.10 & 384.10 \\
\hline
\end{tabular}




\begin{tabular}{|c|c|c|c|c|c|c|c|c|}
\hline$\left({ }^{\circ} \mathrm{C}\right)$ & & & & & & & & \\
\hline $\begin{array}{c}\text { Pressure } \\
(\mathrm{bar})\end{array}$ & 18.25 & 14.50 & 18.25 & 14.50 & 0.80 & 0.80 & 0.80 & 0.80 \\
\hline $\begin{array}{c}\text { Mass flow } \\
(\mathrm{kg} / \mathrm{s})\end{array}$ & 15.20 & 15.20 & 15.20 & 15.20 & 0.95 & 0.90 & 18.61 & 17.78 \\
\hline
\end{tabular}

Compressor Unit for Case 1B: At Downtown campus, Downtown meter point requires saturated steam supply at a pressure of about 10 bar while Life Science meter point requires superheated steam at a pressure of about 18.25 bar. As a result of these two pressure requirements, the inlet pressure condition of the inlet stream into the centralized Boiler1 at HSC is modified to a pressure of about $\mathrm{P}=14.5$ bar to account for pressure loss such that high-pressure steam produced at HSC (centralized surface facility) is delivered to Downtown meter point at a pressure of 10.22 bar while the reciprocating compressor provides additional pressure requirement for Life sciences meter point ( $\mathrm{P}=18.25$ bar). The compressor adiabatic efficiency was assumed to be $75 \%$ (AspenTech default value). For the compressor used to generate superheated steam condition at downtown, the actual steam flow rate $\left(371.9 \mathrm{~m}^{3} / \mathrm{h}\right)$, compressor power $(87.28 \mathrm{~kW})$ and inlet and outlet pressure conditions were fed into Aspen ACCE to estimate the cost of compressor at the required steam as $\$ 581,100$.

Scenario 2 Fired Heater: In Case 2A which supplies saturated steam to the Health Sciences and Evansdale campuses at 12.5 bar, the results show that about $0.60 \mathrm{~kg} / \mathrm{s}$ is required to produce medium pressure steam to be transported to the two campuses. Case $2 \mathrm{~B}$, however, requires 0.56 $\mathrm{kg} / \mathrm{s}$ of natural gas to produce medium pressure steam conditions $(\mathrm{P}=12.5$ bar $)$ to be transported to Health Sciences and Evansdale campuses while natural gas flow rate of about $0.04 \mathrm{~kg} / \mathrm{s}$ is required to provide low pressure steam $(\mathrm{P}=2.75)$ for Towers meter point. The inlet hot water conditions and the outlet steam conditions for the Boiler1 simulated for Case 2A, and Boiler1 and Boiler2 for Case $2 \mathrm{~B}$ as well as exiting flue gas (Flue Gas1) conditions for temperature, pressure, and flow rate are summarized in Table 5-15 below. 
Table 5-15: Inlet hot water, flue gas and high pressure steam outlet conditions for the combustion of natural gas simulated in HYSYS fired heater for Case $2 A$ and Case $2 B$ obtained at a fixed boiler efficiency of $\eta=85 \%$, a fixed boiler hot water inlet temperature of $90^{\circ} \mathrm{C}$ for a given natural gas flow rate.

\begin{tabular}{|c|c|c|c|c|c|c|c|c|}
\hline $\begin{array}{c}\text { Fired } \\
\text { Heater } \\
\text { Output }\end{array}$ & \multicolumn{2}{|c|}{ Hot water inlet } & \multicolumn{2}{|c|}{ Sat. Steam } & \multicolumn{2}{|c|}{ Natural Gas } & \multicolumn{2}{|c|}{ Flue Gas1 } \\
\hline \multicolumn{9}{|c|}{ Case 2A } \\
\hline $\begin{array}{c}\text { Temperature } \\
\left({ }^{\circ} \mathrm{C}\right)\end{array}$ & \multicolumn{2}{|c|}{90.0} & \multicolumn{2}{|c|}{190.0} & \multicolumn{2}{|c|}{63.4} & \multicolumn{2}{|c|}{383.93} \\
\hline $\begin{array}{c}\text { Pressure } \\
\text { (bar) }\end{array}$ & \multicolumn{2}{|c|}{12.5} & \multicolumn{2}{|c|}{12.5} & \multicolumn{2}{|c|}{0.80} & \multicolumn{2}{|c|}{0.80} \\
\hline $\begin{array}{c}\text { Mass flow } \\
(\mathrm{kg} / \mathrm{s})\end{array}$ & \multicolumn{2}{|c|}{10.2} & \multicolumn{2}{|c|}{10.2} & \multicolumn{2}{|c|}{0.57} & \multicolumn{2}{|c|}{11.86} \\
\hline \multicolumn{9}{|c|}{ Case 2B } \\
\hline & Boiler & Boiler & Boiler & Boiler & Boiler & Boiler & Boiler & Boiler \\
\hline & 1 & 2 & 1 & 2 & 1 & 2 & 1 & 2 \\
\hline $\begin{array}{c}\text { Temperature } \\
\left({ }^{\circ} \mathrm{C}\right)\end{array}$ & 90.0 & 90.0 & 191.0 & 136.0 & 63.40 & 15.00 & 383.92 & 157.69 \\
\hline $\begin{array}{c}\text { Pressure } \\
\text { (bar) }\end{array}$ & 12.5 & 2.75 & 12.5 & 2.75 & 0.80 & 0.80 & 0.80 & 0.80 \\
\hline $\begin{array}{c}\text { Mass flow } \\
(\mathrm{kg} / \mathrm{s})\end{array}$ & 9.45 & 0.75 & 9.45 & 0.75 & 0.56 & 0.04 & 10.99 & 0.75 \\
\hline
\end{tabular}

Natural Gas Preheater: The costs of the natural gas preheater are evaluated in Aspen ACCE following simulation of STHE in Aspen HYSYS and detailed design in Aspen EDR. The costs obtained for Scenario 1 and Scenario 2 are presented in following paragraphs.

Heat exchanger cost is determined for the STHE used in fuel preheater simulations. In Scenario 1, a STHE area of about $71.70 \mathrm{~m}^{2}$ and $69.90 \mathrm{~m}^{2}$ is required for Case 1A and Case 1B to transfer about $106.60 \mathrm{~kW}$ and $101.80 \mathrm{~kW}$ of heat energy respectively from the flue gas to preheat natural gas to a temperature of $65^{\circ} \mathrm{C}$. Similarly, Scenario 2 requires STHE area of about $42.40 \mathrm{~m}^{2}$ to transfer about $64 \mathrm{~kW}$ and $62.50 \mathrm{~kW}$ of heat from hot flue gas to obtain a natural gas outlet temperature of $65^{\circ} \mathrm{C}$ for both Case $2 \mathrm{~A}$ and Case $2 \mathrm{~B}$. Table 5.16 shows the result of rigorous STHE design in 
Aspen EDR. The areas obtained from rigorous design of STHE in Aspen EDR are input into Aspen ACCE to estimate the cost of heat exchanger for Scenario 1 as $\$ 0.1 \mathrm{M}$ and $\$ 0.1 \mathrm{M}$ and Scenario 2 as $\$ 0.08 \mathrm{M}$.

Table 5-16: Results of rigorous design in EDR and Aspen ACCE estimation for the natural gas preheater (shell and tube heat exchanger) for Scenario 1 and Scenario 2.

\begin{tabular}{|c|c|c|c|c|}
\hline Case & Case 1A & Case 1B & Case 2A & Case 2B \\
\hline Parameter & Value & Value & Value & Value \\
\hline STHE Area $\left(\mathrm{m}^{2}\right)$ & 71.70 & 69.90 & 39.60 & 39.60 \\
\hline $\begin{array}{c}\text { Overall heat transfer } \\
\text { coefficient U }\left(\mathrm{W} / \mathrm{m}^{2}-\mathrm{K}\right)\end{array}$ & 18.80 & 18.10 & 18.80 & 18.70 \\
\hline Heat Duty $(\mathrm{kW})$ & 106.60 & 101.80 & 63.70 & 62.20 \\
\hline Direct cost $(\mathbf{M}$ ) & $\mathbf{0 . 1 0}$ & $\mathbf{0 . 1 0}$ & $\mathbf{0 . 0 8}$ & $\mathbf{0 . 0 8}$ \\
\hline
\end{tabular}

\subsection{Ammonia ( $\left.\mathrm{NH}_{3}\right)$ Heat Pump System}

Addition of heat pump system to the hybrid GDHC system ensures that geothermal fluid is reinjected back to the reservoir at lower reinjection temperature of $53.83^{\circ} \mathrm{C}$ and $55.56^{\circ} \mathrm{C}$ for Scenario 1 and Scenario 2. The heat pump system maximizes geothermal utilization by extracting more heat from the returning condensate entering the PHE. In Figure 5.3, the cycle begins as $\mathrm{NH}_{3}$ at (NH3EVAP-IN) at $45.60^{\circ} \mathrm{C}$ vaporizes inside the evaporator by extracting heat from lowtemperature returning condensate stream (LTHOTWTRDSTR-IN) and the lower-temperature condensate leaving the evaporator is sent to back to the centralized geothermal plate heat exchanger (PHE) through outlet stream GEOHEX-CLDRETURN. 


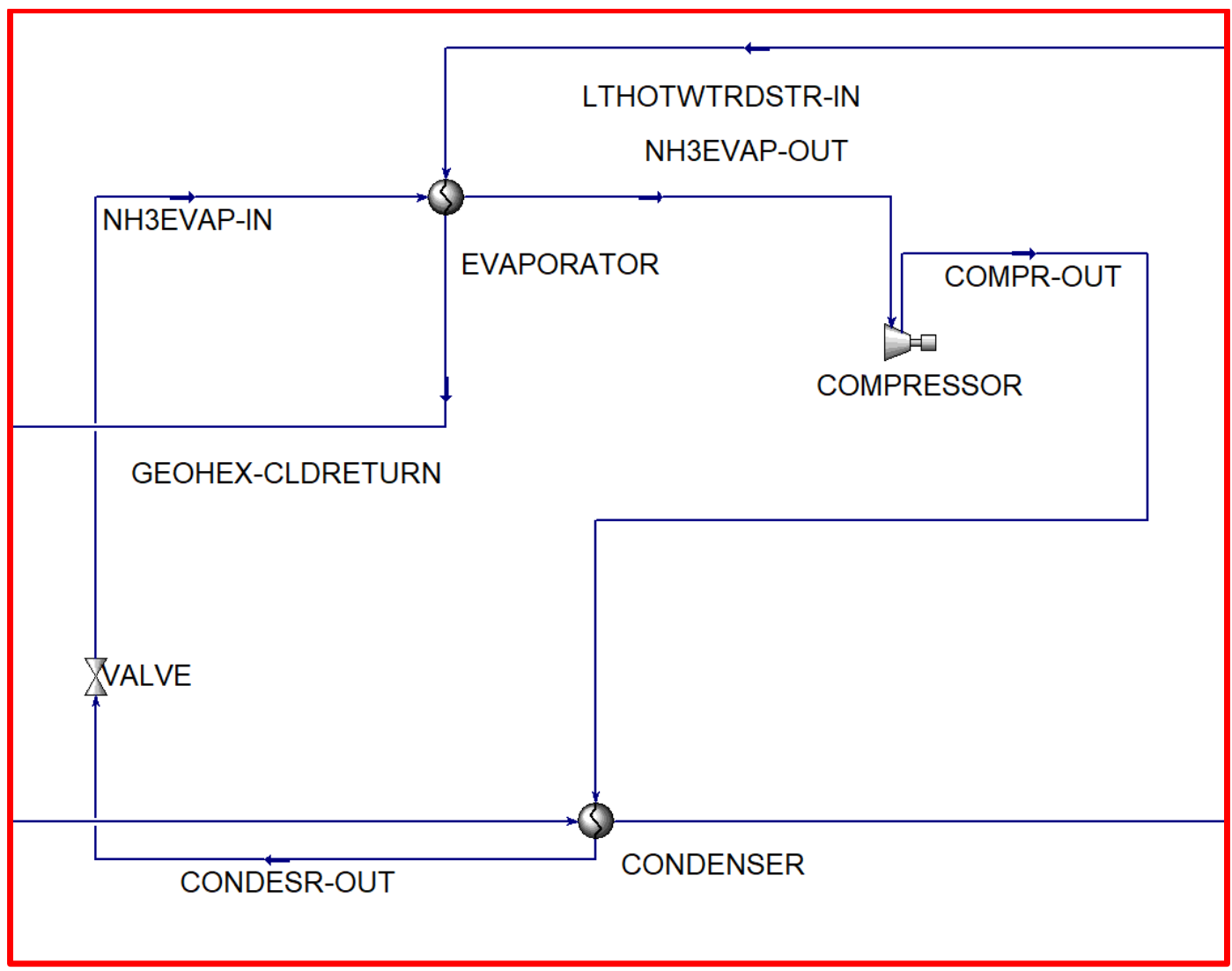

Figure 5.3: The proposed heat pump configuration using ammonia as a working fluid.

Evaporator outlet (NH3EVAP-OUT) passes through the compressor where it is compressed to a higher temperature and pressure of $166.6^{\circ} \mathrm{C}$ and 54 bar respectively. Higher temperature $\mathrm{NH}_{3}$ leaving the compressor (COMPR-OUT) enters the condenser where it is condensed to a lower temperature $\left(92.69^{\circ} \mathrm{C}\right)$ and heat is simultaneously rejected to the geothermally preheated water entering the condenser to further raise its temperature from $75^{\circ} \mathrm{C}$ to $90^{\circ} \mathrm{C}$. Higher temperature hot water leaving the condenser is sent to the natural gas boiler to produce saturated and superheated steam conditions for Scenario 1 and Scenario 2 respectively. The condenser outlet (CONDESROUT) is sent to the expansion valve to lower $\mathrm{NH}_{3}$ pressure and finally, low pressure $\mathrm{NH}_{3}$ returns back to the evaporator to begin another cycle. The heat pump cycle is presented in Figure 5.3 and the pressure-enthalpy (p-h) diagram for ammonia heat pump simulated in HYSYS is shown in Figure 5.4 below. 


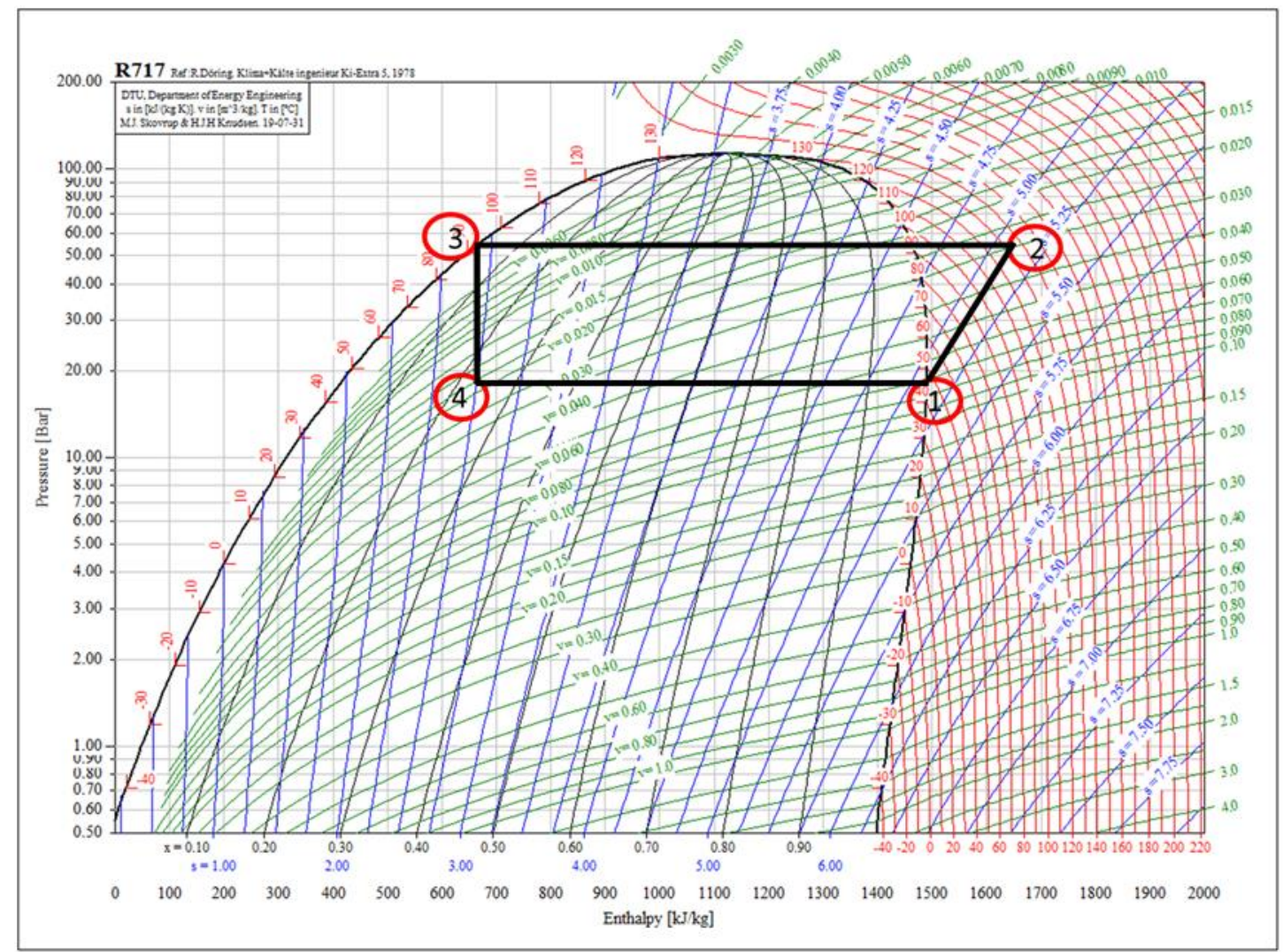

Figure 5.4: Pressure-enthalpy (p-h) diagram of the ammonia heat pump simulated in HYSYS. The major components for the heat pump simulated are represented by compressor (1-2), condenser (2-3), expansion valve (3-4) and evaporator (4-1).

The coefficient of performance (COP) of the heat pump for Scenario 1 and Scenario 2 was determined. As in equation 4.1, the COP is calculated as the ratio of heat rejected by condenser to compressor work input obtained for Case 1A, Case1B, Case 2A, and Case 2B are summarized in Table 5-17 below.

Table 5-17: Results of the coefficient of performance for Scenario 1 and Scenario 2.

\begin{tabular}{|c|c|c|c|}
\hline Case & $\begin{array}{c}\text { Compressor } \\
\text { Work }(\mathbf{k W})\end{array}$ & $\begin{array}{c}\text { Condenser Heat } \\
\text { Rejected }(\mathbf{k W})\end{array}$ & COP \\
\hline Case 1A & 221.33 & 994.41 & 4.49 \\
\hline Case 1B & 221.33 & 994.41 & 4.49 \\
\hline Case 2A & 221.33 & 667.30 & 3.02 \\
\hline Case 2B & 221.33 & 667.30 & 3.02 \\
\hline
\end{tabular}


The calculated Scenario 1 and Scenario 2 COP are 4.49 and 3.02 respectively. From Table 5-17, the work input to the compressor is the same for all cases as the working fluid $\left(\mathrm{NH}_{3}\right)$ flow rate and temperature entering the compressor from the evaporator are the same for the four cases. However, the heat rejected by the condenser differs for Scenario 1 and Scenario 2 as the flow rates of heat absorbing fluid (geothermally preheated water) are different for the two scenarios and hence, different COP.

\subsection{Vendors Quote for Heat Pump and Boiler}

Quotes were obtained for boiler unit and heat pump system simulated in HYSYS. The vendor's quotes obtained were based on process conditions (steam flow rate) and some design parameters (design pressure) as summarized in Table 5-18 and Table 5-19 for the boiler and heat pump system respectively.

\subsubsection{Boiler Vendor's Quote from Johnston Boiler Company (JBC):}

The operating pressure (psig), rated capacity (hp), and steam flow rate (lbs/hr) of dry saturated steam at required pressure obtained from JBC for Scenario 1 and Scenario 2 simulated in HYSYS are presented in Table 5-18 below.

Table 5-18: Vendor's quote obtained from Johnston Boiler Company (JBC) for Scenario 1 and Scenario 2 boilers simulated in HYSYS.

\begin{tabular}{|c|c|c|c|c|c|c|}
\hline Scenario & $\begin{array}{c}\text { Operating } \\
\text { pressure (psig) }\end{array}$ & $\begin{array}{c}\text { Rated } \\
\text { capacity (hp) }\end{array}$ & $\begin{array}{c}\text { Steam flow } \\
\text { rate (lbs/hr) }\end{array}$ & $\begin{array}{c}\text { Boiler unit } \\
\text { cost (\$) }\end{array}$ & $\begin{array}{c}\text { Number } \\
\text { of boilers }\end{array}$ & $\begin{array}{c}\text { Cost } \\
\text { (M\$) }\end{array}$ \\
\hline $\begin{array}{c}\text { Scenario 1 } \\
(300 \#)\end{array}$ & 250.00 & $2,000.00$ & $69,000.00$ & 9.12 & 2 & 1.83 \\
\hline $\begin{array}{c}\text { Scenario 2 } \\
(200 \#)\end{array}$ & 160.00 & $2,200.00$ & $75,900.00$ & 8.76 & 2 & 1.75 \\
\hline
\end{tabular}

At design pressure of 300 psig, Scenario 1 boiler (300\#) is available at a nominal rated capacity of $2,000 \mathrm{hp}, 8.69 \mathrm{~kg} / \mathrm{s}(69,000 \mathrm{lbs} / \mathrm{hr})$ and a total of two boilers would be required to meet the existing meter point steam flow rate flow rate of about $15.2 \mathrm{~kg} / \mathrm{s}(120,636.9 \mathrm{lbs} / \mathrm{hr})$. Scenario 2 boiler 
(200\#), on the other hand, has a design pressure of 200 psig and is available at a nominal rated capacity of 2,200 hp, $9.45 \mathrm{~kg} / \mathrm{s}(75,900 \mathrm{lbs} / \mathrm{hr})$ and a total of two boilers would be required to meet the current meter point steam flow rate requirement of about $10.2 \mathrm{~kg} / \mathrm{s}(80,953.74 \mathrm{lbs} / \mathrm{hr})$ at WVU.

For Scenario 1 (Case 1A and Case 1B), vendor's quote is for saturated dry steam conditions and excluded the cost of the superheated required to produce superheated steam conditions required for Scenario 1. Scenario 2, unlike Scenario 1 requires saturated steam conditions.

\subsubsection{Heat Pump Vendor's Quote from Mayekawa Company:}

Vendor's quotes for heat pump simulated in HYSYS for Scenario 1 and Scenario 2 in Table 5.19 were obtained from the Mayekawa Company. The quotes obtained were based on using $\mathrm{NH}_{3}$ as the working fluid.

Table 5-19: High temperature heat pump package performance obtained from Mayekawa Company.

\begin{tabular}{|c|c|c|c|c|}
\hline Option & Package & $\begin{array}{c}\text { Heating capacity } \\
(\mathbf{M W})\end{array}$ & $\begin{array}{c}\text { Hot water } \\
\text { flow rate (gpm) }\end{array}$ & Cost (M\$) \\
\hline Option \#1 & 4HS package & 1.70 & 770.00 & $\mathbf{0 . 4 1 4}$ \\
\hline Option \#2 & 6HS package & 2.53 & $1,140.00$ & $\mathbf{0 . 4 3 5}$ \\
\hline
\end{tabular}

In Table 5.19, the vendor costs are for two different $\mathrm{NH}_{3}$ heat pump packages that Mayekawa Company can provide for WVU based on the rated process conditions at WVU campus. The two options are similar in design, size and weight. However, Option \#1 uses 4 cylinder high pressure reciprocating compressor to meet a hot flow rate of about $48.51 \mathrm{~kg} / \mathrm{s}$ (770 gpm) while option \#2 uses 6 cylinder compressor to satisfy a higher flow rate requirement of $71.82 \mathrm{~kg} / \mathrm{s}(1,140 \mathrm{gpm})$. At WVU, the maximum flow rate require for Scenario 1 is $15.2 \mathrm{~kg} / \mathrm{s}$ and for Scenario 2 is $10.2 \mathrm{~kg} / \mathrm{s}$ and hence option \#1 is selected as the heat pump capacity require for all cases considered in this work (Scenario 1 and Scenario 2). The operating process conditions for the vendor quote was compared to the conditions obtained from HYSYS simulation in chapter 4. The COP for the vendors quotes (6.18) is higher than 4.49 and 3.02 obtained for Scenario 1 and Scenario 2 in HYSYS as shown in Table 5.20. 
Table 5-20: Mayekawa Company ammonia heat pump quote parameters compared to Aspen Scenario 1 and Scenario 2 heat pump parameters simulated in HYSYS. Red section represents the heat pump system conditions obtained from HYSYS simulation.

\begin{tabular}{|c|c|c|c|c|c|c|c|c|c|c|c|}
\hline \multirow[t]{3}{*}{ Source } & \multicolumn{5}{|c|}{ Scenario 1} & \multicolumn{6}{|c|}{ Scenario 2} \\
\hline & \multicolumn{2}{|c|}{$\begin{array}{l}\text { Heat source } \\
\text { Water }\left({ }^{\circ} \mathbf{C}\right)\end{array}$} & \multicolumn{2}{|c|}{$\begin{array}{c}\text { Hot water } \\
\left({ }^{\circ} \mathrm{C}\right)\end{array}$} & \multirow[t]{2}{*}{ COP } & \multicolumn{2}{|c|}{$\begin{array}{l}\text { Heat source } \\
\text { Water }\left({ }^{\circ} \mathbf{C}\right)\end{array}$} & \multicolumn{2}{|c|}{$\begin{array}{c}\text { Hot water } \\
\left({ }^{\circ} \mathbf{C}\right)\end{array}$} & \multirow[t]{2}{*}{ COP } & \multirow[t]{2}{*}{$\begin{array}{c}\text { Cost } \\
(\$)\end{array}$} \\
\hline & IN & OUT & IN & OUT & & IN & OUT & IN & OUT & & \\
\hline Vendor & 65.0 & 60.0 & 80.0 & 88.0 & 6.18 & 65.0 & 60.0 & 80.0 & 88.0 & 6.18 & 0.41 \\
\hline HYSYS & 65.6 & 52.5 & 75.0 & 90.0 & 4.49 & 65.6 & 54.4 & 75.0 & 90.0 & 3.02 & N/A \\
\hline
\end{tabular}

*N/A not applicable as only vendor's quote was used.

\subsection{HYSYS Pipeline Distribution System Simulations Results and Discussion}

The pressure losses across the pipeline for scenario 1 (entire campus) and scenario 2 (Medical Center, Towers, and Evansdale) were calculated based on Figure 5.5. For the proposed piping system, pressure drop values show the pressure drop in the pipeline is dependent on the steam flow rate, pipe length and the pipe diameter for the two scenarios.

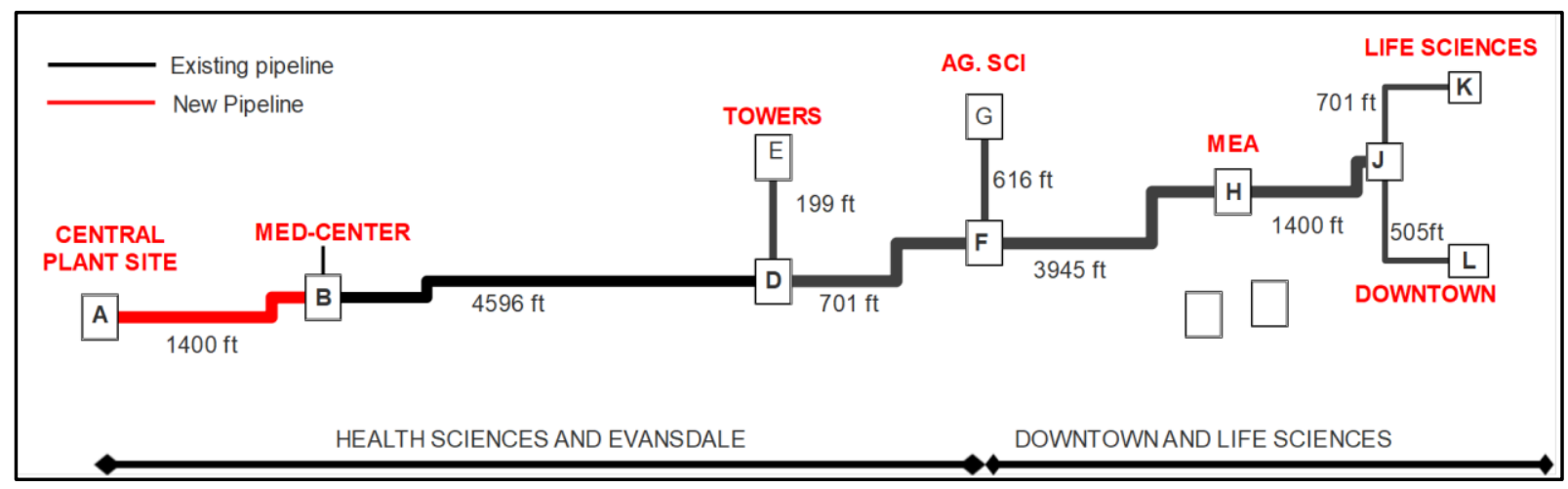

Figure 5.5: Schematic of the proposed steam pipeline distribution from geothermal well site location to the five meters across the entire WVU campus.

\subsubsection{Pressure losses across steam line:}

In scenario 1 (Case 1A and Case 1B), as shown in Table 5.21, pressure drop is highest for the pipeline (BD) with a length of 4,596 ft and a diameter of 10 in because the steam produced is transported over a long distance from Med-center to Tower meter point. The pressure losses across other pipelines were significantly low when compared to the longest pipeline (BD). 
Table 5-21: Pressure drop across the steam pipelines for Scenario 2 (Case 1A and Case 1B). Red section represents new pipelines and black section represents existing MEA pipelines.

\begin{tabular}{|c|c|c|c|c|c|c|}
\hline PFD & Pipe & Length & Diameter & Flow rates & \multicolumn{2}{|c|}{$\Delta$ P (psi) } \\
\cline { 6 - 7 } & & $(\mathbf{f t})$. & $(\mathbf{i n})$ & $(\mathbf{k g} / \mathbf{s})$ & Case 1A & Case 2A \\
\hline AB & HSCLOT81 & 1400 & 14 & 15.20 & 6.14 & 6.80 \\
\hline BD & AGTWRDTN & 4596 & 10 & 8.87 & 29.67 & 34.03 \\
\hline DE & TWR-PIPE & 199 & 4 & 0.78 & 1.29 & 1.52 \\
\hline DF & AG-DTN & 701 & 12 & 8.09 & 1.66 & 1.97 \\
\hline FG & AG-PIPE & 616 & 8 & 3.50 & 2.21 & 2.63 \\
\hline FH & DTN-LFS & 3945 & 12 & 4.59 & 3.13 & 3.73 \\
\hline HJ & DTN-LFS2 & 1996 & 8 & 4.59 & 12.67 & 15.52 \\
\hline JK & LFS-PIPE & 701 & 6 & 0.52 & 0.28 & 0.23 \\
\hline JL & DTN-PIPE & 505.00 & 8.00 & 4.07 & 2.63 & 3.31 \\
\hline
\end{tabular}

Similarly, for Scenario 2 (Case 2A and Case 2B) the pressure losses vary with pipe length, pipe diameter and steam flow rate along the pipeline distribution system as shown in Table 5.22. Pipeline BD also has highest pressure drop for scenario 2. The newly added Towers pipeline pressure drop (NEW-TWR) is comparably high (5.19 psi) because scenario 2B has a separate pipeline which transport a low-pressure steam from the secondary boiler to Towers meter point.

Table 5-22: Pressure drop across steam pipelines for Scenario 2 (Case $2 A$ and Case 2B). Red section represents new pipelines and black section represents existing MEA pipelines.

\begin{tabular}{|c|c|c|c|c|c|c|c|}
\hline \multirow{2}{*}{$\begin{array}{c}\text { PFD } \\
\text { segment }\end{array}$} & \multirow{2}{*}{ Pipe } & \multirow{2}{*}{$\begin{array}{c}\text { Length } \\
(\mathbf{f t} .)\end{array}$} & \multirow{2}{*}{$\begin{array}{c}\text { Diameter } \\
(\mathbf{i n})\end{array}$} & $\begin{array}{c}\text { Flow rates } \\
(\mathbf{k g} / \mathbf{s})\end{array}$ & $\begin{array}{c}\Delta \mathbf{P} \\
(\mathbf{p s i})\end{array}$ & $\begin{array}{c}\text { Flow rates } \\
(\mathbf{k g} / \mathbf{s})\end{array}$ & $\begin{array}{c}\Delta \mathbf{P} \\
(\mathbf{p s i})\end{array}$ \\
\hline AB & HSCLOT81 & 1400 & 14 & 10.20 & 3.52 & 9.45 & 3.03 \\
\hline BD & AG-MEA-1 & 4596 & 10 & 4.11 & 7.94 & 3.36 & 5.32 \\
\hline DE & TWR-PIPE & 199 & 4 & 0.75 & 1.38 & & \\
\hline DF & AG-MEA-2 & 701 & 12 & 3.36 & 0.35 & 3.36 & 0.34 \\
\hline FG & AG-PIPE & 616 & 8 & 3.36 & 2.36 & 3.36 & 2.32 \\
\hline NEW-TWR & NEW-TWR & 5996 & 6 & & & 0.75 & 5.19 \\
\hline
\end{tabular}




\subsubsection{Pressure losses across condensate line:}

The pressure losses across the condensate pipelines for scenario 1 (entire campus) and scenario 2 (Medical Center, Towers, and Evansdale) are shown in Table 5-23 and are dependent on the condensate flow rate, pipe length and the pipe diameter for the two scenarios. For the proposed distribution pipelines, Scenario 1 pressure drop in the pipeline is higher for following three pipelines that transport condensate from downtown meter point (cond-DTN-LFS2 $=46.80 \mathrm{psi}$ ) to downtown MEA point (cond-DTN-LFS=53.42 psi) and from MEA meter point to Evansdale meter point (AGTWRDTN=44.98 psi). The pressure losses are higher for the three pipelines because of their corresponding longer lengths as shown in below.

Table 5-23: Pressure drop across condensate pipelines for Scenario 1. Red section represents new pipelines and black section represents existing MEA pipelines.

\begin{tabular}{|c|c|c|c|c|c|}
\hline $\begin{array}{c}\text { PFD } \\
\text { segment }\end{array}$ & $\begin{array}{c}\text { Length } \\
(\mathbf{f t} .)\end{array}$ & $\begin{array}{c}\text { Diameter } \\
(\mathbf{i n})\end{array}$ & $\begin{array}{c}\text { Flow rates } \\
(\mathbf{k g} / \mathbf{s})\end{array}$ & $\begin{array}{c}\Delta \mathbf{P} \\
(\mathbf{p s i})\end{array}$ \\
\hline AB1 & Cond-HSCLOT81 & 1400 & 6 & 5.70 & 15.77 \\
\hline AB2 & Cond-HSCLOT82 & 1400 & 6 & 7.98 & 15.35 \\
\hline BD & Cond-AGTWRDTN & 4596 & 6 & 7.98 & 44.98 \\
\hline DE & Cond-TWR-PIPE & 199 & 2 & 0.70 & 0.30 \\
\hline DF & Cond-AG-DTN & 701 & 6 & 7.28 & 11.42 \\
\hline FG & Cond-AG-PIPE & 616 & 4 & 3.15 & 0.52 \\
\hline FH & Cond-DTN-LFSC & 3945 & 6 & 4.13 & 53.42 \\
\hline HJ & Cond-DTN-LFSC2 & 1996 & 6 & 4.13 & 47.53 \\
\hline JK & Cond-LFS-PIPE & 701 & 4 & 0.46 & 0.02 \\
\hline JL & Cond-DTN-PIPE & 505 & 6 & 3.67 & 0.06 \\
\hline
\end{tabular}

Similarly, for Scenario 2 (Case 2A and Case 2B), the pressure losses vary with pipe length, pipe diameter and condensate flow rate along the pipeline distribution system represented in Table 5.24. Pipeline BD with largest pipe length (4,596 ft) also has the highest pressure drop of 42.76 psi for scenario 2. The newly added Towers pipeline pressure drop (NEW-TWR) is comparably high (5.19 psi) because scenario $2 \mathrm{~B}$ has a separate pipeline which transport a low-pressure steam from the secondary boiler to Towers meter point. 
Table 5-24: Pressure drop across condensate pipelines for Scenario 2. Red section represents new pipelines and black section represents existing MEA pipelines.

\begin{tabular}{|c|c|c|c|c|c|}
\hline $\begin{array}{c}\text { PFD } \\
\text { segment }\end{array}$ & $\begin{array}{c}\text { Length } \\
(\mathbf{f t} .)\end{array}$ & $\begin{array}{c}\text { Diameter } \\
(\mathbf{i n})\end{array}$ & $\begin{array}{c}\text { Flow rates } \\
(\mathbf{k g} / \mathbf{s})\end{array}$ & $\begin{array}{c}\Delta \mathbf{P} \\
(\mathbf{p s i})\end{array}$ \\
\hline AB1 & Cond-HSCLOT81 & 1400 & 6 & 5.48 & 15.32 \\
\hline AB2 & Cond-HSCLOT82 & 1400 & 6 & 3.70 & 15.08 \\
\hline BD & Cond-AGTWRDTN & 4596 & 6 & 3.70 & 42.76 \\
\hline DE & Cond-TWR-PIPE & 199 & 2 & 0.67 & 0.28 \\
\hline DF & Cond-AG-DTN & 701 & 6 & 3.03 & 11.12 \\
\hline FG & Cond-AG-PIPE & 616 & 4 & 3.03 & 4.95 \\
\hline
\end{tabular}

\subsection{Aspen ACCE Pipeline Cost Results and Discussion}

\subsubsection{Scenario 1 Pipeline Cost from ACCE:}

Pipe costs for the entire campus distribution networks were evaluated in Aspen ACCE using pipe length and pipe diameter for the existing and new pipelines. The new steam and condensate pipeline costs (red section) calculated in Aspen ACCE are compared to the existing steam and condensate pipelines (black section) as shown in Table 5-25 below.

Table 5-25: The result of the pipeline simulated in HYSYS for the steam and condensate pipelines. Red section represents new pipelines and black section represents existing MEA pipelines.

\begin{tabular}{|c|c|c|c|c|c|c|c|}
\hline $\begin{array}{c}\text { Pipe } \\
\text { Tag }\end{array}$ & $\begin{array}{c}\text { Length } \\
(\mathbf{f t})\end{array}$ & $\begin{array}{c}\text { Steam Pipe } \\
\text { Name }\end{array}$ & $\begin{array}{c}\text { Diameter } \\
\text { (in) }\end{array}$ & $\begin{array}{c}\text { Cost } \\
(\mathbf{M} \$)\end{array}$ & $\begin{array}{c}\text { Cond Pipe } \\
\text { Name }\end{array}$ & $\begin{array}{c}\text { Diameter } \\
\text { (in) }\end{array}$ & $\begin{array}{c}\text { Cost } \\
\text { (M\$) }\end{array}$ \\
\hline AB1 & 1,400 & HSCLOT81 & 14 & 0.72 & $\begin{array}{c}\text { Cond- } \\
\text { HSCLOT81 }\end{array}$ & 6 & 0.16 \\
\hline AB2 & & & & & Cond- & 6 & 0.16 \\
\hline BD & 4,596 & AGTWRDTN & 10 & 1.35 & Cond- & 6 & 0.54 \\
\hline DE & 199 & TWR-PIPE & 4 & 0.01 & $\begin{array}{c}\text { Cond-TWR- } \\
\text { PIPE }\end{array}$ & 2 & 0.01 \\
\hline
\end{tabular}




\begin{tabular}{|c|c|c|c|c|c|c|c|}
\hline DF & 701 & AG-DTN & 12 & 0.30 & $\begin{array}{c}\text { Cond-AG- } \\
\text { DTN }\end{array}$ & 6 & 0.08 \\
\hline FG & 616 & AG-PIPE & 8 & 0.01 & $\begin{array}{c}\text { Cond-AG- } \\
\text { PIPE }\end{array}$ & 4 & 0.05 \\
\hline FH & 3,945 & DTN-LFSC & 12 & 1.7 & $\begin{array}{c}\text { Cond-DTN- } \\
\text { LFSC }\end{array}$ & 6 & 0.05 \\
\hline HI & 1,996 & DTN-LFSC2 & 8 & .33 & $\begin{array}{c}\text { Cond-DTN- } \\
\text { LFSC2 }\end{array}$ & 6 & 0.23 \\
\hline JK & 701 & LFS-PIPE & 6 & 0.08 & $\begin{array}{c}\text { Cond-LFS- } \\
\text { PIPE }\end{array}$ & 4 & 0.05 \\
\hline JL & 505 & DTN-PIPE & 8 & 0.08 & $\begin{array}{c}\text { Cond-DTN- } \\
\text { PIPE }\end{array}$ & 6 & 0.06 \\
\hline & & & $\begin{array}{c}\text { Total } \\
\text { Cost (M\$) }\end{array}$ & $\mathbf{4 . 6 8}$ & & Total & $\mathbf{1 . 8 2}$ \\
\hline
\end{tabular}

From the table, the cost of the new steam pipeline to be added to the existing MEA line is about $\$ 0.72 \mathrm{M}$ while the new condensate pipeline is estimated at $\$ 0.33 \mathrm{M}$. Hence, the total cost of purchasing and installing the insulated pipe segmented for the retrofitted pipeline system at WVU is about \$1.04 M for Scenario 1 (Case 1A and Case 1B).

Additional pipeline segment was simulated in HYSYS to transport fuel required for the boiler operation. The pipeline supplies natural gas to the boiler for combustion. The estimated natural gas pipe length for the boiler operation provided by the WVU Facilities Management Team is 3,000 ft. Based on fired heater air-fuel flow rate requirement for Scenario 1 and the given pipe length provided by the WVU Facilities Management, pipe diameter required to transport the required natural gas for Scenario 1 (Case 1A and Case 1B) was obtained as part of the HYSYS simulation setup in chapter 4 . The Scenario 1 cost of natural gas pipeline $(0.18 \mathrm{M} \$)$ is the same for Case 1A and Case 1B.

\subsubsection{Scenario 2 Pipeline Cost from ACCE:}

Pipe length and pipe diameter used for steam and condensate pipeline networks simulation in HYSYS as in section 5.6. Here, the corresponding pipe costs for distribution networks were 
evaluated in Aspen ACCE. The new steam and condensate pipeline costs calculated in Aspen ACCE were compared to the existing steam and condensate pipelines as shown in Table 5-26 and Table 5-27 below.

Table 5-26: The result of Case 2A pipeline simulated in HYSYS for the steam and condensate pipelines.

Red section represents new pipelines and black section represents existing MEA pipelines.

\begin{tabular}{|c|c|c|c|c|c|c|c|}
\hline $\begin{array}{l}\text { Pipe } \\
\text { Tag }\end{array}$ & $\begin{array}{c}\text { Length } \\
\text { (ft) }\end{array}$ & $\begin{array}{c}\text { Steam Pipe } \\
\text { Name }\end{array}$ & $\begin{array}{l}\text { Diameter } \\
\text { (in) }\end{array}$ & $\begin{array}{l}\text { Cost } \\
\text { (M\$) }\end{array}$ & $\begin{array}{l}\text { Cond Pipe } \\
\text { Name }\end{array}$ & $\begin{array}{l}\text { Diameter } \\
\text { (in) }\end{array}$ & $\begin{array}{l}\text { Cost } \\
\text { (M\$) }\end{array}$ \\
\hline $\mathrm{AB}$ & 1,400 & HSCLOT81 & 14 & 0.72 & $\begin{array}{c}\text { Cond- } \\
\text { HSCLOT81-1 }\end{array}$ & 6 & 0.16 \\
\hline $\mathrm{AB} 2$ & 1,400 & & & & $\begin{array}{c}\text { Cond- } \\
\text { HSCLOT81-2 }\end{array}$ & 6 & 0.16 \\
\hline $\mathrm{BD}$ & 4,596 & AGTWRDTN & 10 & 1.35 & $\begin{array}{c}\text { Cond- } \\
\text { AGTWRDTN }\end{array}$ & 6 & 0.54 \\
\hline $\mathrm{DE}$ & 199 & TWR-PIPE & 4 & 0.01 & $\begin{array}{c}\text { Cond-TWR- } \\
\text { PIPE }\end{array}$ & 2 & 0.01 \\
\hline $\mathrm{DF}$ & 701 & AG-DTN & 12 & 0.30 & $\begin{array}{c}\text { Cond-AG- } \\
\text { DTN }\end{array}$ & 6 & 0.08 \\
\hline \multirow[t]{2}{*}{ FG } & 616 & AG-PIPE & 8 & 0.10 & $\begin{array}{l}\text { Cond-AG- } \\
\text { PIPE }\end{array}$ & 4 & 0.05 \\
\hline & & & $\begin{array}{c}\text { Total } \\
\text { Cost (M\$) }\end{array}$ & 2.48 & & $\begin{array}{c}\text { Total } \\
\text { Cost }(M \$)\end{array}$ & 1.01 \\
\hline
\end{tabular}

Table 5-27: The result of Case 2B pipeline simulated in HYSYS for the steam and condensate pipelines. Red section represents new pipelines and black section represents existing MEA pipelines.

\begin{tabular}{|c|c|c|c|c|c|c|c|}
\hline $\begin{array}{c}\text { Pipe } \\
\text { Tag }\end{array}$ & $\begin{array}{c}\text { Length } \\
(\mathbf{f t})\end{array}$ & $\begin{array}{c}\text { Steam Pipe } \\
\text { Name }\end{array}$ & $\begin{array}{c}\text { Diameter } \\
(\mathbf{i n})\end{array}$ & $\begin{array}{c}\text { Cost } \\
(\mathbf{M} \$)\end{array}$ & $\begin{array}{c}\text { Cond Pipe } \\
\text { Name }\end{array}$ & $\begin{array}{c}\text { Diameter } \\
\text { (in) }\end{array}$ & $\begin{array}{c}\text { Cost } \\
\text { (M\$) }\end{array}$ \\
\hline AB & 1,400 & HSCLOT81 & 14 & 0.72 & $\begin{array}{c}\text { Cond- } \\
\text { HSCLOT81-1 }\end{array}$ & 6 & 0.16 \\
\hline AB2 & 1,400 & & & & $\begin{array}{c}\text { Cond- } \\
\text { HSCLOT81-2 }\end{array}$ & 6 & 0.16 \\
\hline $\begin{array}{c}\text { NEW } \\
\text { TWR }\end{array}$ & 5,996 & $\begin{array}{c}\text { NEW TWR } \\
\text { PIPE }\end{array}$ & 6 & 0.71 & & & \\
\hline
\end{tabular}




\begin{tabular}{|c|c|c|c|c|c|c|c|}
\hline BD & 4,596 & AGTWRDTN & 10 & 1.35 & $\begin{array}{c}\text { Cond- } \\
\text { AGTWRDTN }\end{array}$ & 6 & 0.54 \\
\hline DE & 199 & TWR-PIPE & 4 & 0.01 & $\begin{array}{c}\text { Cond-TWR- } \\
\text { PIPE }\end{array}$ & 2 & 0.01 \\
\hline DF & 701 & AG-DTN & 12 & 0.30 & $\begin{array}{c}\text { Cond-AG- } \\
\text { DTN }\end{array}$ & 6 & 0.08 \\
\hline FG & 616 & AG-PIPE & 8 & 0.10 & $\begin{array}{c}\text { Cond-AG- } \\
\text { PIPE }\end{array}$ & 4 & 0.05 \\
\hline & & & $\begin{array}{c}\text { Total } \\
\text { Cost (M\$) }\end{array}$ & $\mathbf{3 . 1 9}$ & & $\begin{array}{c}\text { Total } \\
\text { Cost (M\$) }\end{array}$ & $\mathbf{1 . 0 1}$ \\
\hline
\end{tabular}

From Table 5-26 for Case 2A, the cost of the new steam pipeline to be added to the existing MEA line is about $\$ 0.72 \mathrm{M}$ while the new condensate pipeline is estimated at $\$ 0.33 \mathrm{M}$. The total cost of steam and condensate pipelines for Case 2B (Table 5-27), however, are \$1.42 M (including new Tower pipeline of about $\$ 0.71 \mathrm{M}$ ) and $\$ 0.33 \mathrm{M}$ respectively.

For Case 2A, additional new pipeline segmented was simulated in HYSYS (Section 5.6) to transport fuel required for the boiler operation as presented in Table 5.28. The pipeline supplies natural gas to the boiler for combustion. For Case 2B, on the other hand, two additional new pipelines were simulated. Here, there are two new natural gas pipelines each for Boiler1 and Boiler2 for combustion of natural gas in the two boilers. Similar to Scenario 1, natural gas pipe length of 3,000 $\mathrm{ft}$ was simulated for the boiler operation based on the value provided by WVU Facilities Management Team. Also, the pipe diameter required to transport the required natural gas was based on the air-fuel flow rate for Case 2A and Case 2B obtained from HYSYS simulations in chapter 4. Aspen ACCE costs of new natural gas pipelines are presented in Table 5-28.

Table 5-28: The result of the pipeline simulated in HYSYS for the natural gas pipelines.

\begin{tabular}{|c|c|c|c|c|c|c|c|c|}
\hline \multirow[t]{3}{*}{ Pipe name } & \multicolumn{2}{|c|}{ Pipe length (ft) } & \multicolumn{3}{|c|}{ Diameter (in) } & \multicolumn{3}{|c|}{ Direct cost (M\$) } \\
\hline & \multirow[t]{2}{*}{ Case 2A } & \multirow[t]{2}{*}{ Case 2B } & \multirow[t]{2}{*}{ Case 2A } & \multicolumn{2}{|c|}{ Case 2B } & \multirow[t]{2}{*}{ Case 2A } & \multicolumn{2}{|c|}{ Case 2B } \\
\hline & & & & Pipe1 & Pipe2 & & Pipe1 & Pipe2 \\
\hline NG-PIPE & 3,000 & 3,000 & 6 & 6 & 2 & 0.18 & 0.18 & 0.08 \\
\hline
\end{tabular}


The total cost of new hot water and condensate pipelines and natural gas pipelines costs for Case $1 \mathrm{~A}$, Case $1 \mathrm{~B}$ and Case $2 \mathrm{~A}$ is about $\$ 1.22 \mathrm{M}$ while the total cost for hot water and condensate pipelines and natural gas pipelines as well as the cost of new Towers pipeline estimated for Case 2B Table 5-33 is about $\$ 2.01 \mathrm{M}$.

\subsection{Aspen ACCE Results for Condensate and Hot Water Pump Costs}

\subsubsection{Scenario 1 Condensate and Hot Water Pump Costs}

The pumping capacity for hot water and condensate pumps as well as steam mass flow rate and the pressure head obtained in HYSYS simulations were provided as input into Aspen ACCE to estimate the total capital cost (\$) for the pumping system as shown in the Table 5.29 below.

Table 5-29: Scenario 1 (Case 1A and Case 1B) results of Aspen ACCE pump costs estimated for the hot water and condensate pumps to provide hot water to the boiler unit and transport of condensate to the centralized surface plant for re-use by geothermal heat exchanger.

\begin{tabular}{|c|c|c|c|c|c|c|c|}
\hline Pump Type & Mass Flow & \multicolumn{3}{|c|}{ Case 1A } & \multicolumn{3}{c|}{ Case 1B } \\
\cline { 3 - 8 } & $(\mathbf{k g} / \mathbf{s})$ & $\begin{array}{c}\text { Pressure } \\
\text { Head (ft) }\end{array}$ & $\begin{array}{c}\text { Power } \\
(\mathbf{k W})\end{array}$ & $\begin{array}{c}\text { Cost } \\
(\mathbf{M} \$)\end{array}$ & $\begin{array}{c}\text { Pressure } \\
\text { Head (ft) }\end{array}$ & $\begin{array}{c}\text { Power } \\
(\mathbf{k W})\end{array}$ & $\begin{array}{c}\text { Cost } \\
(\mathbf{M} \$)\end{array}$ \\
\hline $\begin{array}{c}\text { PUMP-1 } \\
\text { (Hot water) }\end{array}$ & 15.20 & 603.50 & 34.28 & 0.06 & 472.30 & 26.82 & 0.06 \\
\hline Cond-PUMP-DTN & 4.13 & 111.90 & 1.73 & 0.04 & 113.30 & 1.75 & 0.04 \\
\hline Cond-PUMP-AG & 7.28 & 26.88 & 0.73 & 0.04 & 26.63 & 0.72 & 0.04 \\
\hline $\begin{array}{c}\text { Cond-PUMP- } \\
\text { TWR }\end{array}$ & 7.98 & 105.90 & 3.16 & 0.05 & 101.10 & 3.01 & 0.05 \\
\hline $\begin{array}{c}\text { Cond-AGDTN- } \\
\text { AGTWRDTN }\end{array}$ & 7.98 & 37.08 & 1.11 & 0.04 & 34.14 & 1.02 & 0.04 \\
\hline Cond-PUMP- & 5.70 & 36.12 & 0.77 & 0.04 & 34.14 & 0.73 & 0.04 \\
\hline MED & & & & & & & \\
\hline Total Cost (M\$) & & & & $\mathbf{0 . 2 8}$ & & & $\mathbf{0 . 2 8}$ \\
\hline
\end{tabular}

At geothermal PHE preheated water outlet flow rate of $15.2 \mathrm{~kg} / \mathrm{s}$, the total pumping cost for the entire campus Case $1 \mathrm{~A}$ hot water and condensate pumps is estimated as $\$ 0.28 \mathrm{M}$ while the total 
cost for pumping system in Case 1B is $\$ 0.28 \mathrm{M}$. One hot water pump and a total of six condensate pumps were required for Case 1A and Case 2B GDHC steam distribution system at WVU.

\subsubsection{Scenario 2 Condensate and Hot Water Pumps Costs}

The pumping capacity of hot water and condensate pumps as well as steam mass flow rate and the pressure head obtained in HYSYS simulations were input into Aspen ACCE to estimate the total capital cost (\$) of the pumping system as shown in the Table 5.30 below.

Table 5-30: Scenario 2 (Case $2 A$ and Case 2B) results of Aspen ACCE pump cost estimate for the hot water and condensate pumps to provide hot water to the boiler unit and transport of condensate to the centralized surface plant for re-use by geothermal heat exchanger. Red section represents the corresponding hot water pump required for the new Tower pipelines.

\begin{tabular}{|c|c|c|c|c|c|c|c|}
\hline Pump Type & $\begin{array}{c}\text { Mass flow } \\
(\mathbf{k g} / \mathbf{s})\end{array}$ & $\begin{array}{c}\text { Pressure } \\
\text { Head (ft) }\end{array}$ & $\begin{array}{c}\text { Power } \\
(\mathbf{k W})\end{array}$ & $\begin{array}{c}\text { Cost } \\
(\mathbf{M} \mathbf{\text { }})\end{array}$ & $\begin{array}{c}\text { Pressure } \\
\text { Head (ft) }\end{array}$ & $\begin{array}{c}\text { Power } \\
(\mathbf{k W})\end{array}$ & $\begin{array}{c}\text { Cost } \\
(\mathbf{M} \mathbf{)})\end{array}$ \\
\hline $\begin{array}{c}\text { PUMP-1 } \\
\text { (Hot water) }\end{array}$ & 10.20 & 402.30 & 15.33 & 0.05 & 402.30 & 14.21 & 0.05 \\
\hline $\begin{array}{c}\text { PUMP-1-2 } \\
\text { (Hot water) }\end{array}$ & & & & & 61.23 & 0.17 & 0.04 \\
\hline Cond-PUMP-MEA & 3.03 & 26.17 & 0.30 & 0.04 & 26.17 & 0.30 & 0.04 \\
\hline Cond-PUMP-TWR & 3.70 & 100.60 & 1.39 & 0.04 & 100.60 & 1.39 & 0.04 \\
\hline $\begin{array}{c}\text { Cond-AGDTN- } \\
\text { AGTWRDTN }\end{array}$ & 3.70 & 35.50 & 0.49 & 0.04 & 35.50 & 0.49 & 0.04 \\
\hline Cond-PUMP-MED & 5.48 & 36.05 & 0.74 & 0.04 & 36.05 & 0.74 & 0.04 \\
\hline Total Cost (M\$) & & & & $\mathbf{0 . 2 1}$ & & & $\mathbf{0 . 2 5}$ \\
\hline
\end{tabular}

In Scenario 2, at a geothermal PHE preheated water outlet flow rate of $10.2 \mathrm{~kg} / \mathrm{s}$, the total pumping cost for the hot water and condensate pipelines in Case 2A is estimated at $\$ 211,300$. However, Case 2B total pumping cost $(\$ 249,300)$ is higher because a new hot water pump is required to provide low pressure hot water to the Boiler2. One hot water pump is required for Case 2A whereas a total of two hot water pumps are required for Case 2B. Scenario 2 requires a total of four condensate pumps for both cases. 


\subsection{Aspen ACCE results for Condensate Receiver Tank Cost}

The volume of the uninsulated condensate tank required for the two scenarios was determined by converting the steam flow rate for the entire campus $(225,000 \mathrm{lb} . / \mathrm{hr}$.) and for the Evansdale and Health Sciences campuses $(145,000 \mathrm{lb} . / \mathrm{hr}$.) to equivalent volume of water in the tank. The tank volume for the two scenarios is obtained by assuming that for the steam systems (1) hot water flow rate is half the hourly rate of evaporation of the steam in the boiler (WVU Facilities Management) and (2) additional tank volume of about one-twelfth of steam flow rate is required for the buffer space during operation. The final tank volume obtained for Scenario 1 and Scenario 2 was used to estimate the cost of condensate tank as shown in Table 5-31 below.

Table 5-31: The results of the cost of the condensate receiver tanks estimated for Scenario 1 and Scenario 2 in Aspen ACCE.

\begin{tabular}{|c|c|c|c|c|}
\hline Scenario & Equipment Type & Parameter & Parameter Value & Cost (M\$) \\
\hline Scenario 1 & Condensate Receiver Tank & Volume $\left(\mathrm{m}^{3}\right)$ & 62.10 & $\mathbf{0 . 2 7}$ \\
\hline Scenario 2 & Condensate Receiver Tank & Volume $\left(\mathrm{m}^{3}\right)$ & 40.00 & $\mathbf{0 . 2 3}$ \\
\hline
\end{tabular}

\subsection{Surface Plant Equipment Utility and Miscellaneous Costs}

The annual utility costs for natural gas and electricity consumption for the boiler and pumping units of the surface plants are estimated. The hours per operating year is assumed to be $8,760 \mathrm{hrs}$. The electricity and natural gas costs are assumed to be $\$ 0.067 / \mathrm{kWh}$ and $\$ 4.12 / 1000 \mathrm{ft}^{3}$ respectively based on current cost of electricity and natural gas provided by WVU Facilities Management Team.

\subsubsection{Pumping System Utility Cost}

The utility cost for pumping hot water into the boiler unit and utility cost for transporting condensate from the various meter points back to the central surface plant facility at HSC was estimated. Pump power (kW) and pump efficiency (80\%) together with the unit cost of electricity were used to obtained annual utility cost for the pumping unit. Annual pumping utility cost estimated for scenario 1 and scenario 2 are summarized in Table 5.32 and Table 5.33 respectively. 
Table 5-32: The result of the utility cost estimated for pumping system at an electricity rate of $\$ 0.067 / \mathrm{kWh}$ for Scenario 1.

\begin{tabular}{|c|c|c|c|c|c|c|}
\hline Pump Type & \multicolumn{3}{|c|}{ Case 1A } & \multicolumn{3}{c|}{ Case 1B } \\
\hline & $\begin{array}{c}\text { Power } \\
(\mathbf{k W})\end{array}$ & $\begin{array}{c}\text { Actual } \\
\text { Power }(\mathbf{k W})\end{array}$ & $\begin{array}{c}\text { Utility } \\
\text { Cost } \mathbf{( \$ )}\end{array}$ & $\begin{array}{c}\text { Power } \\
(\mathbf{k W})\end{array}$ & $\begin{array}{c}\text { Actual } \\
\text { Power }(\mathbf{k W})\end{array}$ & $\begin{array}{c}\text { Utility } \\
\text { Cost } \mathbf{( \$ )}\end{array}$ \\
\hline $\begin{array}{c}\text { PUMP-1 } \\
\text { (Hot water) }\end{array}$ & 34.28 & 42.85 & $25,149.52$ & 26.82 & 33.53 & $19,676.49$ \\
\hline Cond-PUMP-DTN & 1.75 & 2.19 & $1,267.01$ & 1.75 & 2.19 & $1,267.01$ \\
\hline Cond-PUMP-AG & 0.72 & 0.91 & 536.30 & 0.72 & 0.91 & 536.30 \\
\hline Cond-PUMP-TWR & 3.01 & 3.77 & $2,316.13$ & 3.01 & 3.77 & $2,316.13$ \\
\hline $\begin{array}{c}\text { Cond- } \\
\text { AGTWRDTN }\end{array}$ & 1.02 & 1.27 & 810.68 & 1.02 & 1.27 & 810.68 \\
\hline Cond-PUMP-MED & 0.73 & 0.91 & $\mathbf{5 6 4 . 4 0}$ & 0.73 & 0.91 & $\mathbf{5 6 4 . 4 0}$ \\
\hline Total Cost & & & $\mathbf{3 0 , 6 4 4 . 0 5}$ & & & $\mathbf{2 5 , 1 7 1 . 0 2}$ \\
\hline
\end{tabular}

The total utility cost for Case 1A $(\$ 30,644)$ is higher than Case 1B $(\$ 25,171)$ because the total pumping requirement for Case $1 \mathrm{~A}(41.77 \mathrm{~kW})$ is larger than Case $1 \mathrm{~B}(34.31 \mathrm{~kW})$.

Table 5-33: The result of the utility cost estimated for pumping system at an electricity rate of $\$ 0.067 / \mathrm{kWh}$ for Scenario 2. Red section is for additional pump require for the new Towers steam pipeline.

\begin{tabular}{|c|c|c|c|c|c|c|}
\hline Pump Type & \multicolumn{3}{|c|}{ Case 2A } & \multicolumn{3}{c|}{ Case 2B } \\
\hline & $\begin{array}{c}\text { Power } \\
(\mathbf{k W})\end{array}$ & $\begin{array}{c}\text { Actual } \\
\text { Power }(\mathbf{k W})\end{array}$ & $\begin{array}{c}\text { Utility } \\
\text { Cost } \mathbf{( \$ )}\end{array}$ & $\begin{array}{c}\text { Power } \\
(\mathbf{k W})\end{array}$ & $\begin{array}{c}\text { Actual } \\
\text { Power (kW) }\end{array}$ & $\begin{array}{c}\text { Utility } \\
\text { Cost (\$) }\end{array}$ \\
\hline $\begin{array}{c}\text { PUMP-1 } \\
\text { (Hot water) }\end{array}$ & 15.33 & 19.16 & $11,246.85$ & 14.21 & 17.76 & $10,425.17$ \\
\hline $\begin{array}{c}\text { Pump-2 } \\
\text { (Hot water) }\end{array}$ & & & & 0.17 & 0.21 & 125.75 \\
\hline Cond-PUMP-MEA & 0.30 & 0.38 & 217.09 & 0.30 & 0.38 & 217.09 \\
\hline Cond-PUMP-TWR & 1.40 & 1.75 & $1,020.51$ & 1.40 & 1.75 & $1,020.51$ \\
\hline $\begin{array}{c}\text { Cond-PUMP- } \\
\text { AGTWR }\end{array}$ & 0.47 & 0.59 & 360.15 & 0.47 & 0.59 & 360.15 \\
\hline Cond-PUMP-MED & 0.70 & 0.87 & 541.51 & 0.70 & 0.87 & 541.51 \\
\hline Total Cost & & & $\mathbf{1 3 , 3 8 6 . 1 0}$ & & & $\mathbf{1 2 , 6 9 0 . 1 6}$ \\
\hline
\end{tabular}


Similarly, the total utility cost for Case 2A $(\$ 13,386.10)$ is higher than Case 2B $(\$ 12,690.16)$ because the total pumping requirement for Case $2 \mathrm{~A}(18.25 \mathrm{~kW})$ is larger than Case $2 \mathrm{~B}(17.30 \mathrm{~kW})$.

\subsubsection{Compressor Utility Cost}

For Scenario 1 Case 1B, the compressor power $(\mathrm{kW})$ and efficiency were used to estimate the annual utility cost for the compressor at about $\$ 68,301$ as represented in Table 5.34 below.

Table 5-34: The result of the utility cost estimated for the compressor at an electricity rate of $\$ 0.067 / \mathrm{kWh}$.

\begin{tabular}{|c|c|c|c|}
\hline Pump Type & $\begin{array}{c}\text { Power } \\
(\mathbf{k W})\end{array}$ & $\begin{array}{c}\text { Actual Power } \\
(\mathbf{k W})\end{array}$ & $\begin{array}{c}\text { Annual Utility Cost } \\
(\mathbf{\$})\end{array}$ \\
\hline Compressor & 87.28 & 116.37 & $\mathbf{6 8 , 3 0 1}$ \\
\hline
\end{tabular}

\subsubsection{Air blower Utility Cost}

The utility cost for air blower for the boiler unit was estimated using air blower power $(\mathrm{kW})$ and efficiency (75\%). The unit cost of electricity was used to obtained annual utility cost for the air blower. Annual pumping utility cost estimated for scenario 1 (Case 1A and Case 1B) and scenario 2 (Case 2A and Case 2B) are summarized in Table 5.35 below.

Table 5-35: The result of the utility cost estimated for the air blower at an electricity rate of $\$ 0.067 / \mathrm{kWh}$.

\begin{tabular}{|c|c|c|c|}
\hline Case & $\begin{array}{c}\text { Power } \\
(\mathbf{k W})\end{array}$ & $\begin{array}{c}\text { Actual Power } \\
(\mathbf{k W})\end{array}$ & $\begin{array}{c}\text { Annual Utility Cost } \\
(\mathbf{M} \mathbf{)})\end{array}$ \\
\hline Case 1A & 606.39 & 808.51 & 0.47 \\
\hline Case 1B & 579.37 & 772.49 & 0.45 \\
\hline Case 2A & 363.91 & 485.21 & 0.28 \\
\hline Case 2B & 358.43 & 477.90 & 0.28 \\
\hline TOTAL & & & $\mathbf{1 . 4 9}$ \\
\hline
\end{tabular}

\subsubsection{Natural Gas Boiler Utility Cost}

The annual utility cost for the natural gas boiler operation was determined from the unit cost of purchasing natural gas at a rate of $\$ 3.68 / G J$ which is based on the dollars per thousand cubic feet 
$\left(\$ 4.12 / 1000 \mathrm{ft}^{3}\right)$ of natural gas supply at WVU. Boiler heat duty $(\mathrm{kW})$ and boiler efficiency $(85 \%)$ together with the unit cost of natural gas were used to obtained annual natural gas utility cost. Annual natural gas utility cost obtained for Scenario 1 (Case 1A at 5.37 M\$ and Case 1B at 5.13 $\mathrm{M} \$$ ), and Scenario 2 (Case 2A (3.22 M\$), and Case 2B (3.42 M\$)) are summarized in

Table 5-36 below.

Table 5-36: Scenario 1 and Scenario 2 results of the utility cost estimated for natural gas supply at a rate of $\$ 4.12 / 1000 \mathrm{ft}^{3}$.

\begin{tabular}{|c|c|c|c|c|}
\hline \multicolumn{2}{|c|}{ Case } & $\begin{array}{c}\text { Heat Duty } \\
\text { (MW) }\end{array}$ & $\begin{array}{c}\text { Actual Heat Duty } \\
\text { (MW) }\end{array}$ & $\begin{array}{c}\text { NG Utility Cost } \\
\text { (M\$) }\end{array}$ \\
\hline \multicolumn{2}{|c|}{ Case 1A } & 39.33 & 46.27 & $\mathbf{5 . 3 7}$ \\
\hline \multicolumn{2}{|c|}{ Case 1B } & 37.58 & 44.21 & $\mathbf{5 . 1 3}$ \\
\hline Case 3 (Boiler1) & 23.61 & 27.77 & $\mathbf{3 . 2 2}$ \\
\hline \multirow{3}{*}{ Case 4 } & Boiler1 & 23.45 & 27.35 & 3.17 \\
\cline { 2 - 5 } & Boiler2 & 1.79 & 2.10 & 0.24 \\
\cline { 2 - 5 } & TOTAL & & & $\mathbf{3 . 4 2}$ \\
\hline
\end{tabular}

\subsubsection{Heat Pump Utility Cost}

Scenario 1 and Scenario 2 annual heat pump utility cost for power $(221.3 \mathrm{~kW})$ and efficiency $(75 \%)$ is estimated as $\$ 0.17 \mathrm{M}$. 


\section{Objective 4: Perform an Economic Analysis to Estimate the Levelized Cost of Heat (LCOH) Using GEOPHIRES}

In this chapter, the total costs of associated major surface plant equipment and distribution pipelines required for the economic evaluation are summarized. The total surface plant costs estimated combined with subsurface, surface, and financial parameters were used to run GEOPHIRES simulations [22]. The LCOH for the proposed hybrid GDHC is determined using GEOPHIRES software, while the LCOH for the natural gas fired boiler (NGFB) system without geothermal or heat pump is calculated in Microsoft Excel.

\subsection{Economic Evaluation}

Following the design of the surface plant for the DHC system at WVU, an economic evaluation of the proposed hybrid GDHC system was performed in GEOPHIRES. GEOPHIRES is a software used to perform techno-economic analysis of a geothermal energy system [22], [45], [58]. Here, the objective is to determine the economic feasibility of the hybrid GDHC system in order to compare the costs and benefits of the proposed hybrid GDHC system with the existing MEA coalfired steam-based system. To achieve this objective, first the LCOH was evaluated in GEOPHIRES [22], [40], [41], [58], [59]. The parameters used to calculate the levelized cost of heat $(\mathrm{LCOH})$ include:

- The amount of heat produced over the project lifetime (30 years)

- The capital cost of investment and

- Operating and maintenance costs $(\mathrm{O} \& \mathrm{M})$

To calculate LCOH, GEOPHIRES has built-in correlations to estimate the capital cost of investment and O\&M costs [45].

The capital cost of investment $\left(C_{c a p}\right)$ is calculated as the sum of:

- Well drilling and completion $\operatorname{cost}\left(C_{\text {well }}\right)$

- Reservoir stimulation costs $\left(C_{\text {stim }}\right)$

- Fluid distribution costs $\left(C_{\text {distr }}\right)$

- Resource exploration costs $\left(C_{\text {expl }}\right)$

- Surface plant equipment and distribution costs $\left(C_{\text {surf }}\right)$ 
The sum of these costs $\left(\mathrm{C}_{\text {cap }}\right)$ are summarized as follows:

$$
C_{\text {cap }}=C_{\text {well }}+C_{\text {stim }}+C_{\text {dist }}+C_{\text {expl }}+C_{\text {surf }}
$$

However, surface plant cost model available in GEOPHIRES is only suitable for simple cost calculations as the model is not applicable for detailed estimation of the major components of the surface plant equipment and distribution pipelines costs $\left(\mathrm{C}_{\text {surf }}\right)$. As a result, Aspen Plus, Aspen HYSYS and Aspen exchanger design and rating (EDR) were used in basic surface plant equipment and distribution network simulations and designs while the costs of various components of the equipment employed in the surface plant designs were estimated using Aspen economic analyzer including Aspen capital cost estimator (ACCE). Certain equipment costs including natural gas boiler and heat pump system, on the other hand, were obtained from the vendors.

Similarly, the annual plant operating and maintenance costs $\left(C_{O \& M}\right.$, plant $)$ are calculated as the sum of:

- Surface plant O\&M costs $\left(C_{O \& M}\right.$ surf $)$

- Wellfield O\&M costs $\left(C_{O \& M}\right.$, well $)$

- Make-up water costs (CO\&M, water $)$

- Surface plant utilities and natural gas costs $\left(C_{U \& N G,}\right.$ surf $)$

The sum of these costs $\left(C_{O \& M}\right.$, plant $)$ are summarized as follows:

$$
C_{\text {plant }}=C_{O \& M, \text { surf }}+C_{O \& M, \text { well }}+C_{O \& M, \text { water }}+C_{U \& N G, \text { surf }}
$$

However, the rate of water loss in the geothermal reservoir is assumed to be negligible. As a result, the annual expenses for the make-up water is assumed to be zero for the GDHC system at WVU.

\subsubsection{Editing GEOPHIRES}

In this work, the hybrid geothermal-natural gas boiler district heating and cooling system was designed for the WVU. GEOPHIRES V2.0 python code [45], however, can only simulate and calculate LCOH for the geothermal system. Consequently, GEOPHIRES code was edited to account for the hybrid system in the LCOH calculation. GEOPHIRES code was modified for the hybrid system to include the following parameters in LCOH calculation: 
- Boiler heating duty

- Natural gas utility cost

The boiler heat duty is obtained from Aspen simulators. The total annual natural gas utility cost is calculated based on the annual fuel flow rate required for steam production by the boiler. The utility costs for the pump, compressor and air blower are calculated using the average electricity rate for the WVU campus $(\$ 0.067 / \mathrm{kWh})$.

\subsubsection{Levelized Cost of Heat (LCOH) Model}

Currently, there are three economic models available in GEOPHIRES to calculate LCOH. These models are:

1. Fixed charge rate (FCR) model

2. Standard levelized cost (SLC) model

3. BICYCLE levelized life cycle cost model

However, BICYCLE levelized cost model is the most robust model [60]. The BICYCLE model was used to evaluate feasibility of GDHC system at WVU because it is the most complex and the most realistic economic model which accounts for inflation rate, tax rates and tax credits. The model assumes the GDHC system at WVU is financed through debt (bonds) and equity and allows variation of the ratio of these two variables to model LCOH [59]. The LCOH expressed in \$/MMBTU is calculated as follows:

$$
L C O H=\frac{N P V}{\sum_{t=1}^{n} \frac{W_{t} x\left(1+i_{\text {inf }}\right)^{t}}{\left(1+i^{\prime}\right)^{t}}}
$$

where $N P V$ is the net present value, $i_{\text {inf }}$ is the inflation rate, $i^{\prime}$ is the average return on investment and $W_{t}$ is the nominal thermal output in $\mathrm{kW}_{\text {th }}$, and $n$ is the plant life (30 years).

\subsection{Levelized Cost of Heat ( $\mathrm{LCOH})$ Calculations}

Levelized cost of heat estimates here are primarily based on the existing district heating and cooling system at WVU and may have ignored other important features that may be specific to 
other locations. LCOH may depend significantly on other factors such as drilling costs, geothermal gradient, operating hours or energy utilization factor, flow rate per well, surface plant O\&M costs, plant lifetime, discount rates, economic risk and regional considerations including existing infrastructure. Furthermore, no subsidies, tax incentives, $\mathrm{CO}_{2}$ credits were included in the $\mathrm{LCOH}$ calculations. For comparison purposes, $\mathrm{LCOH}$ comparisons should take these factors into consideration as geothermal resource is geographically localized.

\subsection{Total Surface Plant and Capital Cost for Scenario 1 and Scenario 2.}

As stated in section 6.1, there is no built-in correlations in GEOPHIRES to calculate surface plant cost. Thus, costs of the major surface plant equipment for Scenario 1 (Case 1A and Case 1B and Scenario 2 (Case 2A and Case 2B) were obtained in Aspen ACCE. The direct costs of purchasing geothermal surface plant equipment including plate heat exchanger, fuel preheater, hot water and condensate pumps, condensate receiver tank as well as the costs of retrofitted pipelines obtained in Aspen ACCE are summarized in Table 6-1. In addition, as well as the vendor's quotes for the boiler and heat pump system are also presented in Table 6-1. Indirect costs including construction expense, contingency, contractor fees and engineering expenses are assumed to be $35 \%$ of the total direct and indirect costs [57], [61]. Hence, the total surface plant indirect costs for Scenario 1 and Scenario 2 are obtained as $54 \%$ of the total direct costs. The sum of direct and indirect costs is the fixed capital investment [57]. The fixed capital investment is equivalent to total module costs [62]. Total capital investment is made up of fixed capital investment and working capital. Working capital is the additional cost, apart from fixed capital investment, to startup the project and keep the surface plant in operation. The working capital necessary for the hybrid surface plant operation is assumed to be $20 \%$ of the total capital investment for the project [57]. Scenario 1 and Scenario 2 working capital is calculated as $25 \%$ of the fixed capital investment (total direct and indirect costs). The utility costs for the pumping system, compressor, natural gas and air blower and the total capital costs for the surface plant facilities make up the total project costs summarized in Table 6-1. The annual O\&M costs for the surface plant equipment is estimated to be $20 \%$ of the total surface plant cost and they are assumed to scale with the size of the surface equipment. 
Table 6-1: Aspen ACCE results, vendors quote and utility costs for the surface plant equipment for Scenario 1, which supplies superheated steam to the entire campus and for Scenario 2, which supplies saturated steam to Health Sciences and Evansdale (Towers and Evansdale) campuses.

\begin{tabular}{|c|c|c|c|c|}
\hline \multicolumn{5}{|c}{ Scenario 1 and Scenario 2 Total Project Cost Summary (M\$) } \\
\hline Equipment type & Case 1A & Case 1B & Case 2A & Case 2B \\
\hline Heat Exchanger & 0.22 & 0.22 & 0.17 & 0.17 \\
\hline *Boiler 1 (Fired Heater) & 1.83 & 1.83 & 1.75 & 1.75 \\
\hline *Boiler 2 (Fired Heater) & - & - & - & 0.88 \\
\hline Compressor (reciprocating) & - & 0.58 & - & - \\
\hline Condensate Receiver Tank & 0.27 & 0.27 & 0.24 & 0.24 \\
\hline Natural Gas Preheater & 0.10 & 0.10 & 0.09 & 0.09 \\
\hline Heat Pump Vendor's Quote & 0.41 & 0.41 & 0.41 & 0.41 \\
\hline Total & $\mathbf{2 . 8 4}$ & $\mathbf{3 . 4 2}$ & $\mathbf{2 . 6 6}$ & $\mathbf{3 . 5 4}$ \\
\hline \hline Pump Costs & & & & \\
\hline Hot water Pump & 0.06 & 0.06 & 0.05 & 0.09 \\
\hline Condensate Pump & 0.22 & 0.22 & 0.16 & 0.16 \\
\hline Total Pump Cost & $\mathbf{0 . 2 8}$ & $\mathbf{0 . 2 7}$ & $\mathbf{0 . 2 1}$ & $\mathbf{0 . 2 5}$ \\
\hline Pipeline Costs & $\mathbf{1 . 2 2}$ & & & \\
\hline Retrofitted Steam Pipeline & 0.72 & 0.72 & 0.72 & 1.42 \\
\hline Retrofitted Condensate Pipeline & 0.33 & 0.33 & 0.33 & 0.33 \\
\hline Natural Gas pipeline & 0.18 & 0.18 & 0.18 & 0.18 \\
\hline Natural Gas pipeline2 & - & - & - & 0.08 \\
\hline Total Pipeline Cost & $\mathbf{1 . 2 2}$ & $\mathbf{1 . 2 2}$ & $\mathbf{2 . 0 1}$ \\
\hline Total Surface Plant Indirect Costs & $\mathbf{1 . 3 7}$ & $\mathbf{1 . 8 9}$ & $\mathbf{1 . 5 8}$ & $\mathbf{2 . 2 3}$ \\
\hline Total Working Capital & $\mathbf{1 . 3 4}$ & 4.09 & 5.80 \\
\hline Total Capital Cost & 2.68 & 2.21 & 3.13 \\
\hline \hline
\end{tabular}

*Vendor's quote was used.

Case 1A with a centralized surface facility including heat exchanger, boiler, heat pump system, condensate receiver tank, all located at HSC, will require a less total capital cost but a little more annual utility costs when compared to Case $1 \mathrm{~B}$ with associated cost of a compressor. 
Similar to Scenario 1, the total capital cost for Case 2A is lower than Case 2B. In addition, the total utility cost for Case $2 \mathrm{~A}(\$ 3.67 \mathrm{M} /$ year) is lower than for case $2 \mathrm{~B}(\$ 3.86 /$ year). Thus, Case 2A is a more attractive option because it has lower total capital and utility costs when compared to Case 2B. Therefore, designing a centralized surface facility for Case $2 \mathrm{~A}$ is a better alternative for Scenario 2 .

Natural Gas Fired Boiler (NGFB) System: The case of producing steam with NGFB (no geothermal) for the WVU is evaluated for the total surface plant capital costs (direct and indirect costs), utility costs and $\mathrm{LCOH}$. In this case, the costs of the surface plant equipment and distribution pipeline networks for GDHCS system do not include geothermal PHE and heat pump costs as shown in Table 6.2. Because LCOH calculation available in GEOPHIRES software is specific to geothermal system, the LCOH for the NGFB system without geothermal is manually calculated in Microsoft Excel using BICYCLE economic model.

Table 6-2: Natural gas boiler Aspen ACCE results, vendors quote and utility costs for the surface plant equipment for Scenario 1 which supplies superheated steam to the entire campus and for Scenario 2 which supplies saturated steam to Health Sciences and Evansdale (Towers and Evansdale) campuses.

\begin{tabular}{|c|c|c|c|c|}
\hline \multicolumn{5}{|c|}{ Scenario 1 and Scenario 2 Total Project Cost Summary (M\$) } \\
\hline Equipment type & Case 1A & Case 1B & Case 2A & Case 2B \\
\hline Boiler 1 (Fired Heater) & 1.83 & 1.83 & 1.75 & 1.75 \\
\hline Boiler 2 (Fired Heater) & - & - & - & 0.88 \\
\hline Compressor (reciprocating) & - & 0.58 & - & - \\
\hline Condensate Receiver Tank & 0.27 & 0.27 & 0.24 & 0.24 \\
\hline Natural Gas Preheater & 0.10 & 0.10 & 0.09 & 0.09 \\
\hline Total & $\mathbf{2 . 2 0}$ & $\mathbf{2 . 7 8}$ & $\mathbf{2 . 0 8}$ & $\mathbf{2 . 9 5}$ \\
\hline Pump Costs & & & & \\
\hline Hot water Pump & & & & \\
\hline Condensate Pump & 0.06 & 0.06 & 0.05 & 0.09 \\
\hline Total Pump Cost & 0.28 & 0.27 & 0.21 & 0.25 \\
\hline
\end{tabular}




\begin{tabular}{|c|c|c|c|c|}
\hline Pipeline Costs & & & & \\
\hline Retrofitted Steam Pipeline & 0.72 & 0.72 & 0.72 & 1.42 \\
\hline Retrofitted Condensate Pipeline & 0.33 & 0.33 & 0.33 & 0.33 \\
\hline Natural Gas pipeline & 0.18 & 0.18 & 0.18 & 0.18 \\
\hline Natural Gas pipeline2 & - & - & - & 0.08 \\
\hline Total Pipeline Cost & $\mathbf{1 . 2 2}$ & $\mathbf{1 . 2 2}$ & $\mathbf{1 . 2 2}$ & $\mathbf{2 . 0 1}$ \\
\hline & & & & \\
\hline Total Surface Plant Direct Costs & 4.23 & 4.74 & 3.37 & 4.49 \\
\hline Total Surface Plant Indirect Costs & 2.29 & 2.56 & 1.82 & 2.43 \\
\hline Total Working Capital & 1.63 & 1.83 & 1.30 & 1.73 \\
\hline Total Capital Cost & $\mathbf{7 . 1 2}$ & $\mathbf{8 . 2 3}$ & $\mathbf{6 . 7 5}$ & $\mathbf{1 0 . 0 3}$ \\
\hline O\&M Cost & & & & \\
\hline Utility Costs & $\mathbf{1 . 6 3}$ & $\mathbf{1 . 8 3}$ & $\mathbf{1 . 3 0}$ & $\mathbf{1 . 7 3}$ \\
\hline Pump & & & & \\
\hline Compressor & & & & \\
\hline Natural Gas Boiler & 5.37 & 5.13 & 3.22 & 3.17 \\
\hline Natural Gas Boiler1 & - & - & - & 0.24 \\
\hline Air Blower & 0.47 & 0.45 & 0.28 & 0.28 \\
\hline $\mathbf{5 . 4 0}$ & $\mathbf{5 . 2 3}$ & $\mathbf{3 . 2 4}$ & $\mathbf{3 . 4 3}$ \\
\hline
\end{tabular}

\subsection{Economic Analysis in GEOPHIRES}

\subsubsection{Economic Analysis of Scenario 1 and Scenario 2 with Existing MEA Distribution Pipelines}

Assuming existing distribution pipelines are donated by MEA, economic analysis of the GDHC system for WVU campus is performed in GEOPHIRES using BICYCLE economic model to calculate LCOH [63]. The input fed into GEOPHIRES for the base case LCOH is based on the parameter values in Table 6-3.

Table 6-3: Parameters input into GEOPHIRES for Scenario 1 and Scenario 2 Hybrid GDHC system at WVU. 


\begin{tabular}{|c|c|c|}
\hline \multicolumn{3}{|c|}{ SUBSURFACE TECHNICAL PARAMETERS } \\
\hline Parameter & Vertical & Horizontal \\
\hline Reservoir Model & User Temperature Data & User Temperature Data \\
\hline Reservoir Depth (km) & 2.9 & 2.9 \\
\hline Reservoir Water Loss Rate (\%) & 0 & 0 \\
\hline Reservoir Heat Capacity $(\mathrm{J} / \mathrm{kg} / \mathrm{K})$ & 1000 & 1000 \\
\hline Reservoir Density $\left(\mathrm{kg} / \mathrm{m}^{3}\right)$ & 2500 & 2500 \\
\hline Reservoir Thermal Conductivity $(\mathrm{W} / \mathrm{m} / \mathrm{K})$ & 2 & 2 \\
\hline Geothermal Gradient $\left({ }^{\circ} \mathrm{C} / \mathrm{km}\right)$ & 26 & 26 \\
\hline Well Configuration (-) & Doublet & Doublet \\
\hline Well Inner Diameter (inch) & 8 & 8 \\
\hline Production Wellbore Heat Transfer & Ramey's Model & Ramey's Model \\
\hline Reinjection Temperature $\left({ }^{\circ} \mathrm{C}\right)$ & 50 & 50 \\
\hline Production Fluid Flow Rate $(\mathrm{kg} / \mathrm{s})$ & Variable & Variable \\
\hline Reservoir Impedance $\left(\mathrm{GPa}^{*} \mathrm{~s} / \mathrm{m}^{3}\right)$ & Variable & Variable \\
\hline \multicolumn{3}{|c|}{ SURFACE TECHNICAL PARAMETERS } \\
\hline Parameter & Default & WVU Value \\
\hline End-Use Option & Direct-Use & Direct-Use \\
\hline Circulation Pump Efficiency & 0.75 & 0.8 \\
\hline Utilization Factor & 0.95 & 0.95 \\
\hline End-Use Efficiency Factor & 0.9 & 0.9 \\
\hline Ambient Temperature $\left({ }^{\circ} \mathrm{C}\right)$ & 13.5 & 13.5 \\
\hline \multicolumn{3}{|c|}{ FINANCIAL PARAMETERS } \\
\hline Parameter & Default & WVU Value \\
\hline Plant Lifetime (years) & 30 & 30 \\
\hline Economic Model & 3 (BICYCLE) & 3 (BICYCLE) \\
\hline Fraction of Investment in Bonds & 0.5 & 0.5 \\
\hline Inflated Bond Interest Rate & 0.05 & 0.05 \\
\hline Inflated Equity Interest Rate & 0.1 & 0.1 \\
\hline Inflation Rate & 0.02 & 0.02 \\
\hline
\end{tabular}




\begin{tabular}{|c|c|c|}
\hline Combined Income Tax Rate & 0.3 & 0.3 \\
\hline Electricity Rate $(\$ / \mathrm{kWh})$ & 0.07 & 0.067 \\
\hline Heat Rate $(\$ / \mathrm{kWh})$ & 0.02 & $0.0512(\$ 15 / \mathrm{MMBTU})$ \\
\hline
\end{tabular}

The inflation rate was chosen to be $2 \%$ because it is the average of all reported values [63]. The combined income tax rate was considered to be $30 \%$ based on the values reported by [63]. The utilization factor of $95 \%$ at WVU was assumed because geothermal is used all year round, heating in the winter and cooling in the summer. Ramey's heat model was used to estimate the wellbore heat losses or well temperature drop [64]. The temperature profile used for the reservoir model was based on the result from a reservoir simulator known as Tough2/EOS1. The re-injection temperatures in Table 6-3 above is $50^{\circ} \mathrm{C}$ (bottom hole temperature) for both Scenario 1 and Scenario 2. No gross revenue tax, investment tax credit and property tax, $\mathrm{CO}_{2}$ credits, and subsidies were considered in determination of LCOH by GEOPHIRES. The electricity rate $(\$ 0.067 / \mathrm{kWh})$ and the heat price of $\$ 0.051 / \mathrm{kWh}$ are based on the current rates for the WVU. The heat price for the LCOH calculation is based on the existing contract agreement between WVU and MEA (WVU Facilities Management) and is higher than the average of $\$ 0.02 / \mathrm{kWh}$ reported in the literature [63]. Aspen simulators surface plant equipment design results, subsurface technical parameters, estimated O\&M costs and other important input text file parameters required for GEOPHIRES simulations are summarized in Table 6.4 below. These parameters were parts of the major input text files fed into GEOPHIRES to calculate LCOH for the WVU. 
Table 6-4: Aspen simulators output, surface technical parameters, utility costs, total capital costs and O\&M costs fed into GEOPHIRES to determine LCOH at WVU.

\begin{tabular}{|c|c|c|c|c|}
\hline Parameter & Case 1A & Case 1B & Case 2A & Case 2B \\
\hline Subsurface Technical Parameters \\
\hline Production Well Flow rate $(\mathrm{kg} / \mathrm{s})$ & 15.20 & 15.20 & 10.20 & 10.20 \\
\hline Reservoir Impedance for Horizontal Well $\left(\mathrm{GPa}^{*} \mathrm{~s} / \mathrm{m}^{3}\right)$ & 0.11 & 0.11 & 0.11 & 0.11 \\
\hline Injection Temperature $\left({ }^{\circ} \mathrm{C}\right)$ & 50.00 & 50.00 & 50.00 & 50.00 \\
\hline Surface/Simulation Parameters & 0.82 & 0.82 & 0.83 & 0.83 \\
\hline Boiler Heat Duty $(\mathrm{MJ} / \mathrm{s})$ & 39.33 & 37.58 & 25.08 & 25.04 \\
\hline Surface Utility Cost Parameters & 41.77 & 34.31 & 18.20 & 17.25 \\
\hline Total Pump Power $(\mathrm{kW})$ & - & 87.28 & - & - \\
\hline Total Compressor Power k(W) & 606.39 & 579.37 & 363.91 & 358.43 \\
\hline Air Blower Power $(\mathrm{kW})$ & 221.30 & 221.30 & 221.30 & 221.30 \\
\hline Heat Pump Power $(\mathrm{kW})$ & 8.34 & 9.46 & 7.88 & 11.16 \\
\hline Surface Plant Costs & 1.67 & 1.89 & 1.58 & 2.23 \\
\hline
\end{tabular}

Also, the boiler heat duties calculated for the two scenarios in HYSYS were included as part of the GEOPHIRES inputs used to calculate LCOH. In LCOH calculation, local well costs obtained from Northeast Natural energy (NNE) were compared to the generalized well cost correlation in GEOPHIRES to provide a range of values for the $\mathrm{LCOH}$ in order to account for the uncertainty involved in drilling geothermal wells.

Table 6.5 and Table 6-6 show that the levelized cost of heating (LCOH) for a hybrid system at WVU campus ranges from 7.55 to 10.90 \$MMBTU for vertical well and 7.77 to 11.60 \$/MMBTU for horizontal well configuration. 
Table 6-5: The results of economic analysis for Scenario 1 and Scenario 2 simulated in GEOPHIRES for the vertical well.

\begin{tabular}{|c|c|c|c|c|c|c|c|c|}
\hline \multirow{2}{*}{$\begin{array}{c}\text { Vertical Well } \\
\text { Parameter }\end{array}$} & \multicolumn{4}{|c|}{ NNE Well costs } & \multicolumn{4}{|c|}{ Default Well costs } \\
\hline & $\begin{array}{c}\text { Case } \\
1 \mathrm{~A}\end{array}$ & $\begin{array}{c}\text { Case } \\
1 B\end{array}$ & $\begin{array}{c}\text { Case } \\
2 \mathrm{~A}\end{array}$ & $\begin{array}{c}\text { Case } \\
2 B\end{array}$ & $\begin{array}{c}\text { Case } \\
\text { 1A }\end{array}$ & $\begin{array}{c}\text { Case } \\
1 B\end{array}$ & $\begin{array}{c}\text { Case } \\
2 \mathrm{~A}\end{array}$ & $\begin{array}{c}\text { Case } \\
\text { 2B }\end{array}$ \\
\hline $\begin{array}{l}\text { Average Direct-Use Heat } \\
\text { Production (MWth) }\end{array}$ & 1.88 & 1.88 & 1.18 & 1.18 & 1.88 & 1.88 & 1.18 & 1.18 \\
\hline $\begin{array}{l}\text { Annual Heat Income } \\
\text { (MS/Yr) }\end{array}$ & 18.54 & 17.75 & 11.81 & 11.80 & 18.54 & 17.75 & 11.81 & 11.80 \\
\hline $\begin{array}{l}\text { Well Drilling and Completion } \\
\text { Costs }(\mathrm{M} \$ / \text { Well })\end{array}$ & 2.10 & 2.10 & 2.10 & 2.10 & 5.24 & 5.24 & 5.24 & 5.24 \\
\hline $\begin{array}{l}\text { Field Gathering System Costs } \\
\qquad(\mathrm{M} \$)\end{array}$ & 1.27 & 1.27 & 1.15 & 0.98 & 1.27 & 1.27 & 1.15 & 1.15 \\
\hline Exploration Costs $(\mathrm{M} \$)$ & 2.91 & 2.91 & 2.91 & 2.91 & 5.14 & 5.14 & 5.14 & 5.14 \\
\hline Surface Plant Costs $(\mathrm{M} \$)$ & 8.43 & 9.54 & 7.88 & 11.16 & 8.43 & 9.54 & 7.88 & 11.16 \\
\hline Total Capital Costs $(\mathrm{M} \$)$ & 16.72 & 17.84 & 16.14 & 19.42 & 25.23 & 26.35 & 24.65 & 27.93 \\
\hline $\begin{array}{l}\text { Well Field Maintenance Costs } \\
\qquad(\mathrm{M} \$ / \mathrm{Yr})\end{array}$ & 0.12 & 0.12 & 0.12 & 0.12 & 0.18 & 0.18 & 0.18 & 0.18 \\
\hline $\begin{array}{l}\text { Surface Plant O\&M Costs } \\
\qquad(\mathrm{M} \$ / \mathrm{Yr})\end{array}$ & 1.67 & 1.89 & 1.58 & 2.23 & 1.67 & 1.89 & 1.58 & 2.23 \\
\hline Natural Gas Costs $(\mathrm{M} \$ / \mathrm{Yr})$ & 5.43 & 5.19 & 3.46 & 3.45 & 5.43 & 5.19 & 3.46 & 3.45 \\
\hline $\begin{array}{l}\text { Surface Plant Pump Utility Costs } \\
\qquad(\mathrm{M} \$ / \mathrm{Yr})\end{array}$ & 0.03 & 0.03 & 0.01 & 0.01 & 0.03 & 0.03 & 0.01 & 0.01 \\
\hline $\begin{array}{l}\text { Compressor Utility Costs } \\
\qquad(\mathrm{M} \$ / \mathrm{Yr})\end{array}$ & - & 0.07 & - & - & - & 0.07 & - & - \\
\hline Air Blower Utility Costs $(\mathrm{M} \$ / \mathrm{Yr})$ & 0.47 & 0.45 & 0.28 & 0.28 & 0.47 & 0.45 & 0.28 & 0.28 \\
\hline Heat Pump Utility Costs (M\$/Yr) & 0.17 & 0.17 & 0.17 & 0.17 & 0.17 & 0.17 & 0.17 & 0.17 \\
\hline $\begin{array}{l}\text { Average Annual Downhole } \\
\text { Pumping }(\mathrm{M} \$ / \mathrm{Yr})\end{array}$ & 0.13 & 0.13 & 0.06 & 0.06 & 0.13 & 0.13 & 0.06 & 0.06 \\
\hline Total O\&M Costs $(\mathrm{M} \$ / Y r)$ & 8.03 & 8.05 & 5.69 & 6.33 & 8.09 & 8.11 & 5.75 & 6.39 \\
\hline LCOH (\$MMBTU) & 7.55 & 7.98 & 8.82 & 9.97 & 8.14 & 8.59 & 9.74 & 10.90 \\
\hline
\end{tabular}


Table 6-6: The results of economic analysis for Scenario 1 and Scenario 2 simulated in GEOPHIRES for the horizontal well.

\begin{tabular}{|c|c|c|c|c|c|c|c|c|}
\hline \multirow{2}{*}{$\begin{array}{c}\text { Horizontal Well } \\
\text { Parameter }\end{array}$} & \multicolumn{4}{|c|}{ NNE Well costs } & \multicolumn{4}{|c|}{ Default Well costs } \\
\hline & $\begin{array}{c}\text { Case } \\
\mathbf{1 A}\end{array}$ & $\begin{array}{c}\text { Case } \\
1 B\end{array}$ & $\begin{array}{l}\text { Case } \\
\mathbf{2 A}\end{array}$ & $\begin{array}{c}\text { Case } \\
\text { 2B }\end{array}$ & $\begin{array}{c}\text { Case } \\
\mathbf{1 A}\end{array}$ & $\begin{array}{c}\text { Case } \\
1 \mathrm{~B}\end{array}$ & $\begin{array}{c}\text { Case } \\
2 \mathrm{~A}\end{array}$ & $\begin{array}{l}\text { Case } \\
\text { 2B }\end{array}$ \\
\hline $\begin{array}{l}\text { Average Direct-Use Heat } \\
\text { Production (MWth) }\end{array}$ & 1.85 & 1.85 & 1.17 & 1.17 & 1.85 & 1.85 & 1.17 & 1.17 \\
\hline $\begin{array}{l}\text { Annual Heat Income } \\
\text { (MS/Yr) }\end{array}$ & 18.53 & 17.74 & 11.81 & 11.79 & 18.53 & 17.74 & 11.81 & 11.79 \\
\hline $\begin{array}{l}\text { Well Drilling and Completion } \\
\text { Costs (M\$/Well) }\end{array}$ & 3.80 & 3.80 & 3.80 & 3.80 & 7.86 & 7.86 & 7.86 & 7.86 \\
\hline $\begin{array}{l}\text { Field Gathering System Costs } \\
\qquad(\mathrm{M} \$)\end{array}$ & 1.04 & 1.04 & 1.01 & 1.01 & 1.04 & 1.04 & 1.01 & 1.01 \\
\hline Exploration Costs (M\$) & 4.22 & 4.22 & 4.22 & 4.22 & 7.07 & 7.07 & 7.07 & 7.07 \\
\hline Surface Plant Costs $(\mathrm{M} \$)$ & 8.34 & 9.46 & 7.88 & 11.16 & 8.34 & 9.46 & 7.88 & 11.16 \\
\hline Total Capital Costs (M\$) & 21.21 & 22.33 & 20.71 & 23.99 & 32.17 & 33.29 & 31.67 & 34.95 \\
\hline $\begin{array}{l}\text { Well Field Maintenance Costs } \\
\qquad(\mathrm{M} \$ / \mathrm{Yr})\end{array}$ & 0.15 & 0.15 & 0.15 & 0.15 & 0.23 & 0.23 & 0.23 & 0.23 \\
\hline $\begin{array}{l}\text { Surface Plant O\&M Costs } \\
\qquad(\mathrm{M} \$ / \mathrm{Yr})\end{array}$ & 1.67 & 1.89 & 1.58 & 2.23 & 1.67 & 1.89 & 1.58 & 2.23 \\
\hline Natural Gas Costs $(\mathrm{M} \$ / \mathrm{Yr})$ & 5.43 & 5.19 & 3.46 & 3.45 & 5.43 & 5.19 & 3.46 & 3.45 \\
\hline $\begin{array}{l}\text { Surface Plant Pump Utility Costs } \\
\qquad(\mathrm{M} \$ / \mathrm{Yr})\end{array}$ & 0.03 & 0.03 & 0.01 & 0.01 & 0.03 & 0.03 & 0.01 & 0.01 \\
\hline $\begin{array}{l}\text { Compressor Utility Costs } \\
\qquad(\mathrm{M} \$ / \mathrm{Yr})\end{array}$ & - & 0.07 & - & - & - & 0.07 & - & - \\
\hline Air Blower Utility Costs (M\$/Yr) & 0.47 & 0.45 & 0.28 & 0.28 & 0.47 & 0.45 & 0.28 & 0.28 \\
\hline Heat Pump Utility Costs (M\$/Yr) & 0.17 & 0.17 & 0.17 & 0.17 & 0.17 & 0.17 & 0.17 & 0.17 \\
\hline $\begin{array}{l}\text { Average Annual Downhole } \\
\text { Pumping (M\$Yr) }\end{array}$ & 0.01 & 0.01 & 0.01 & 0.01 & 0.01 & 0.01 & 0.01 & 0.01 \\
\hline Total O\&M Costs $(\mathrm{M} \$ / \mathrm{Yr})$ & 7.94 & 7.96 & 5.67 & 6.31 & 8.02 & 8.04 & 5.75 & 6.39 \\
\hline LCOH (\$/MMBTU) & 7.77 & 8.21 & 9.25 & 10.41 & 8.53 & 9.00 & 10.44 & 11.60 \\
\hline
\end{tabular}


The two scenarios evaluated require a 16.72 to $27.93 \mathrm{M} \$$ capital investment for the vertical well and a 21.21 to $34.95 \mathrm{M} \$$ for the horizontal well. Total capital cost for the horizontal well configuration simulated in GEOPHIRES is considerably higher than a typical total capital cost for the vertical well because the cost of drilling horizontal well using either GEOPHIRES correlations or NNE well costs is usually higher than the cost of drilling vertical well. Using the existing distribution system for the two scenarios, $\mathrm{LCOH}$ for the hybrid-natural gas GDHC system at WVU for Scenario 1 and Scenario 2 appears to be lower than a typical value for GDHC system range of about 16 to 17 \$MMBTU reported in the literature [59], [65].

\subsubsection{Economic Analysis of Scenario 1 and Scenario 2 with Purchase of Distribution Pipelines}

The current pipeline distribution system for heating and cooling at WVU belongs to MEA. When the existing contract between WVU and MEA ceases, MEA distribution pipeline would either be donated or purchased by West Virginia University. To account for uncertainty related to the distribution pipeline system, based on the estimated pipeline costs provided by WVU Facilities Management, $\mathrm{LCOH}$ value is determined for:

- Additional capital cost of \$15 M if existing distribution pipelines are purchased from MEA by WVU.

- Additional capital cost of \$25 M if a new set of pipelines are purchased and installed for the WVU campus.

For Scenario 1 and Scenario 2 as shown in Table 6-1 and Table 6-2, the calculated values for the $\mathrm{LCOH}$ increase greatly with increasing capital costs for both default and NNE well costs assuming new distribution pipelines are purchased or installed by WVU. For the NNE well cost, the range of levelized cost is from 8.50 to 12.45 \$/MMBTU for vertical well configuration and 8.72 to 12.89 \$/MMBTU for horizontal well configuration. For the case of using default well costs available in GEOPHIRES, the range of levelized cost is from around 9.08 to 13.38 \$MMBTU for vertical well and 9.47 to 14.08 \$MMBTU for horizontal well. 


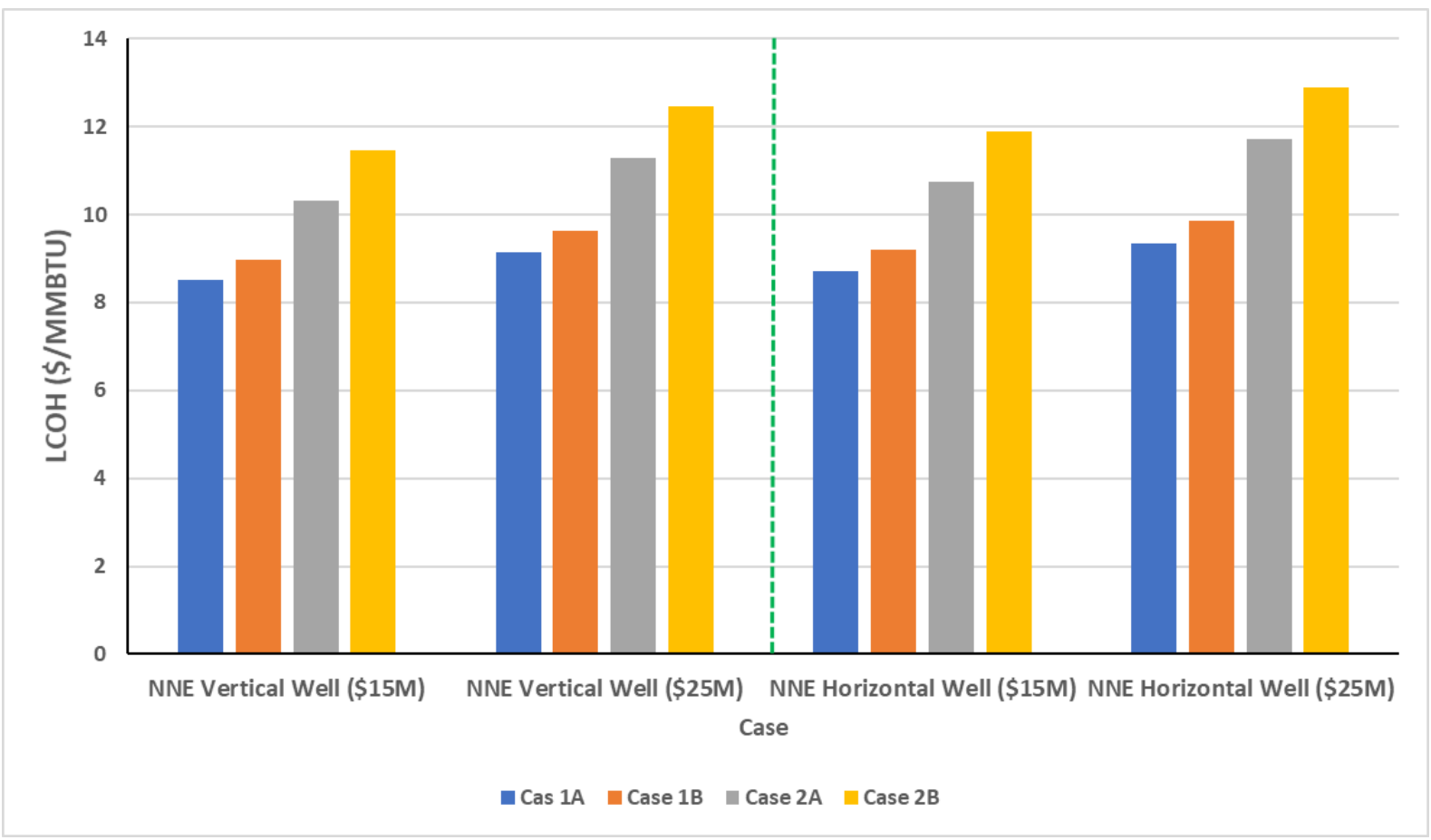

Figure 6.1: Scenario 1 (Case 1A and Case 1B) and Scenario 2 (Case 2A and Case 2B) LCOH values simulated in GEOPHIRES for NNE well at additional capital costs of \$15M and \$25M.

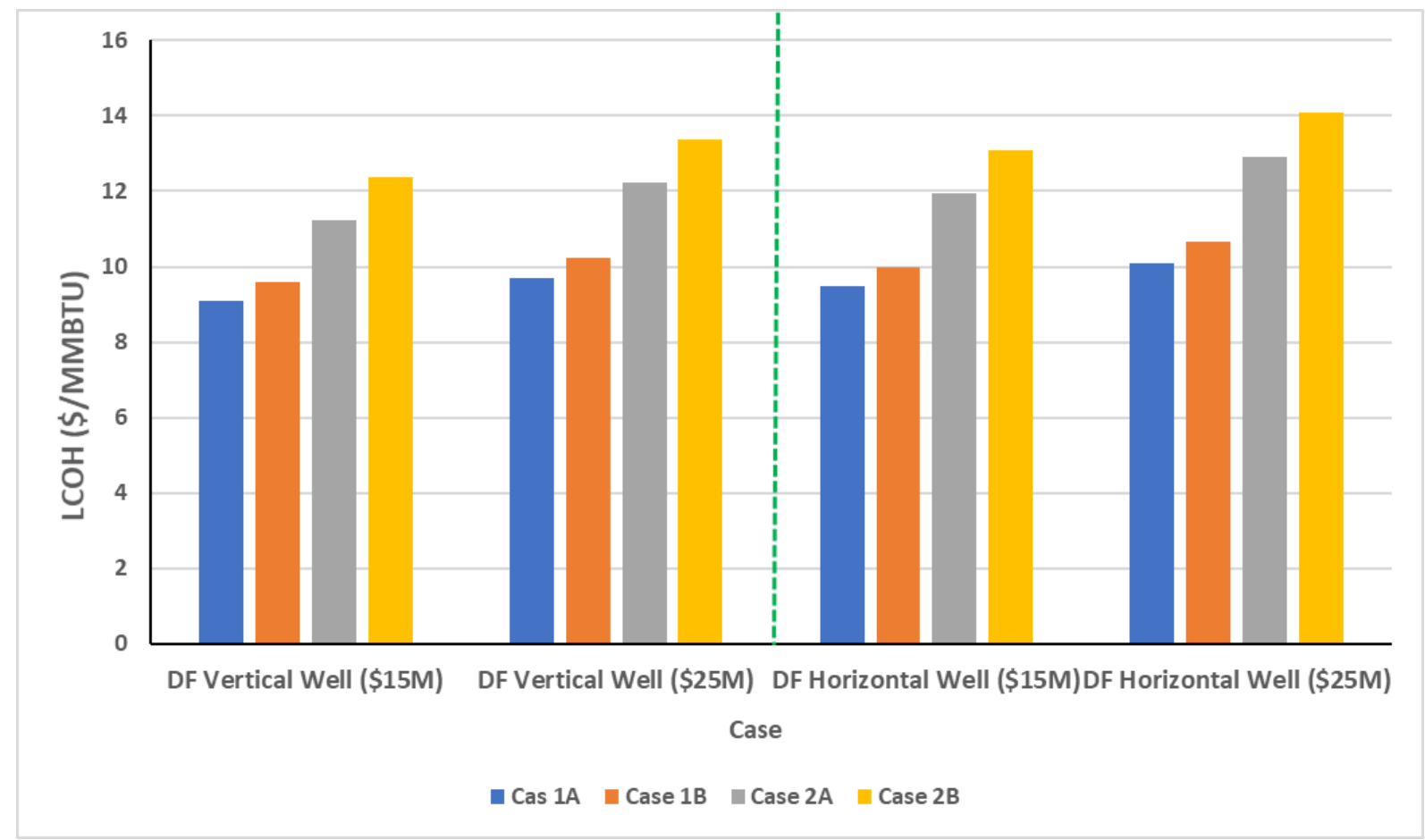

Figure 6.2: Scenario 1 (Case $1 A$ and Case 1B) and Scenario 2 (Case $2 A$ and Case 2B) values simulated in GEOPHIRES for default (DF) well at additional capital costs of \$15M and \$25M. 
In Figure 6.1 and Figure 6.2, Case 1A has the lowest LCOH and Case 2B has the highest LCOH for the two scenarios simulated in GEOPHIRES. In general, the ranges of LCOH values for Case 1A, Case 1B, Case 2A, and Case 2B for the horizontal well are higher than the vertical well.

However, the levelized cost of heat ( $\mathrm{LCOH})$ for natural gas-fired boiler without geothermal, as shown in Table 4-1, ranges from 5.65 to 7.46 \$/MMBTU.

Table 6-7: The results of excel LCOH calculation for NGFB using BICYCLE economic model for Scenario 1 and Scenario 2.

\begin{tabular}{|c|c|c|c|c|}
\hline Parameters & Case 1A & Case 1B & Case 2A & Case 2B \\
\hline Total Capital Costs (M\$) & 7.12 & 8.23 & 6.75 & 10.03 \\
\hline Surface Plant O\&M Costs (M\$/Yr) & 1.42 & 1.65 & 1.35 & 2.01 \\
\hline Total Utility Cost (M\$) & 5.40 & 5.23 & 3.24 & 3.43 \\
\hline Total O\&M Costs (M\$Y) & 6.83 & 6.87 & 4.59 & 5.44 \\
\hline LCOH (\$/MMBTU) & $\mathbf{5 . 6 5}$ & $\mathbf{6 . 0 1}$ & $\mathbf{6 . 1 3}$ & $\mathbf{7 . 4 6}$ \\
\hline
\end{tabular}

Analysis of the economic feasibility of the two scenarios shows that the ranges of LCOH determined from this study are lower than the typical value in the literature, which suggests that the proposed hybrid GDHC system can be developed for the WVU assuming that existing pipelines are donated by MEA. However, the ranges of LCOH values obtained from NGFB system without geothermal are comparably lower than the proposed hybrid GDHC system.

\subsection{Fuel Price Analysis for Case 1A}

Future price of fuel will have a major impact on the $\mathrm{LCOH}$ and hence, economic feasibility of the project. Because of uncertainty regarding the natural gas prices, further analysis is carried out for Case 1A to determine the price of natural gas at which the proposed hybrid GDHC system is more economical than the NGFB. The current price of natural gas supplied to WVU is at $\$ 4.12 / 1000 \mathrm{ft}^{3}$. The value of LCOH obtained for different prices of natural gas for the proposed hybrid system is compared to the NGFB system as shown in Table 6-8. 
Table 6-8: The LCOH results of the proposed hybrid GDHC system compared with NGFB system at different natural gas prices for Case 1A.

\begin{tabular}{|c|c|c|}
\hline $\begin{array}{l}\text { Natural Gas Price } \\
\qquad\left(\$ / 1000 \mathbf{f t}^{3}\right)\end{array}$ & $\begin{array}{c}\text { LCOH_Hybrid } \\
\text { (\$/MMBTU) }\end{array}$ & $\begin{array}{c}\text { LCOH_NGFB } \\
\text { (\$/MMBTU) }\end{array}$ \\
\hline 10.00 & 12.72 & 12.21 \\
\hline 11.00 & 13.68 & 13.28 \\
\hline 12.00 & 14.64 & 14.36 \\
\hline 13.00 & 15.59 & 15.43 \\
\hline 14.00 & 16.55 & 16.50 \\
\hline 15.00 & 17.51 & 17.57 \\
\hline 16.00 & 18.46 & 18.64 \\
\hline 17.00 & 19.42 & 19.71 \\
\hline 18.00 & 20.38 & 20.78 \\
\hline 19.00 & 21.33 & 21.85 \\
\hline 20.00 & 22.29 & 22.92 \\
\hline
\end{tabular}

From Table 6-8, the price of natural gas for which the hybrid system is economical is calculated to be $\$ 15.00 / 1000 \mathrm{ft}^{3}$. Below the natural gas price of $\$ 15.00 / 1000 \mathrm{ft}^{3}$, the proposed hybrid GDHC system cannot compete with NGFB as the gas price is significantly lower and hence, NGFB without geothermal system would be a preferable alternative. When the natural gas price, on the other hands, rises above $\$ 15.00 / 1000 \mathrm{ft}^{3}$ proposed hybrid GDHC system would be more attractive as the $\mathrm{LCOH}$ value would be considerably lower than the NGFB. 


\section{Conclusions and Recommendations for the Future Work}

\subsection{Conclusions}

In addition to an elevated temperature hot spot found beneath the Tuscarora Sandstone in Morgantown, WVU campus has a potential of using geothermal year-round because there is a relatively large student population (over 30,000) with a dense arrangement of about 245 campus buildings on 1,892 acres. Thus, WVU's Morgantown campus has been identified as a prime location in the eastern United States for the development of a geothermal direct-use heating and cooling system application.

The main goal of this project was to perform a feasibility analysis of developing a GDHC system for the WVU campus in Morgantown. First, this work evaluated the current DHC system at West Virginia University and proposed the use of existing DHC system together with the geothermal system to supply steam to various campuses. Because the expected geofluid from the well cannot meet the campus steam demand at temperatures below $100^{\circ} \mathrm{C}$, the potential of using lowtemperature geothermal energy with a natural gas boiler was assessed. Aspen simulators were used to design the proposed geothermal surface plant for the GDHC system at WVU. Natural gas-fired boiler was integrated with the geothermal system and hence, a hybrid GDHC system was designed. The resulting hybrid geothermal-natural gas district heating and cooling system was proposed to replace the existing MEA coal-fired steam-based system.

Because geothermal contribution to the proposed heating and cooling system was very low, this study further focused on improving the hybrid GDHC system design with the heat pump system. The heat pump system improvement for the hybrid GDHC system was achieved by further preheating secondary fluid temperature from $75^{\circ} \mathrm{C}$ to $90^{\circ} \mathrm{C}$ and the improved hybrid system performance was boosted by maximizing geothermal energy utilization in order to minimize the levelized cost of heat (LCOH). Thus, an integrated hybrid GDHC system with higher efficiency was achieved using a heat pump. For all scenarios considered in this work, geothermal contributes between 2.30 to $2.43 \%$ to the heating and cooling system at WVU while the improved hybrid GDHC system with a heat pump contributes between 4.05 to $4.39 \%$. 
The total capital costs for the two scenarios were determined in Aspen ACCE. Surface plant equipment and distribution costs for the four cases provided the input required to calculate $\mathrm{LCOH}$ in GEOPHIRES. After obtaining the surface plant capital costs, the BICYCLE model was used to calculate the LCOH at WVU. The feasibility of the GDHC system was determined by comparing costs of the proposed hybrid GDHC system with the existing MEA coal-fired steam-based system.

Currently, WVU pays $\$ 15 / M M B T U$ for steam supplies by MEA. The preliminary assessment from the previous work by Nandanwar et. al. [66] calculated LCOH to be \$11.73/MMBTU for the WVU campus. Utilizing existing pipeline distribution system, this work found the LCOH for both Scenario 1 and Scenario 2 in the ranges of 7.55 to $10.90 \$ / M M B T U$ for the vertical well configuration and 7.77 to 11.60 \$MMBTU for the horizontal well configuration. For the proposed hybrid GDHC system, the higher LCOH attributed to horizontal well cost is primarily due to the well drilling costs as the key factor in determining the cost of geothermal project is well drilling and completion [52], [66]. This offers the vertical well configuration a slight advantage over the horizontal well because the drilling cost is lower. To address uncertainty related to the distribution system, the LCOH for additional capital costs of purchasing (15 M\$) or installing (25 M\$) new pipelines were performed for both Scenario 1 and Scenario 2. Purchasing or installing new pipeline distribution facilities if existing pipeline networks are not donated by MEA resulted in $\mathrm{LCOH}$ in the range of 8.50 to 12.89 \$MMBTU which is lower than LCOH values of 16 to 17 \$MMBTU reported in the literature [41], [52], [64].

For the two scenarios, proposed hybrid GDCH system could be considered for the WVU campus because the ranges of levelized cost of heat $(\mathrm{LCOH})$ obtained for both scenario 1 and scenario 2 are lower than current cost of steam supplies by MEA (15 \$MMBTU). In contrast, at the current price of natural gas $\left(\$ 4.02 / 1000 \mathrm{ft}^{3}\right)$ supplied for the WVU, the levelized cost of heat $(\mathrm{LCOH})$ for natural gas-fired boiler system without geothermal is comparatively lower as LCOH values are in the range of 5.65 to $7.46 \$$ MMBTU. For a natural gas price above $\$ 15.00 / 1000 \mathrm{ft}^{3}$, the $\mathrm{LCOH}$ values for the proposed hybrid system would be comparably lower than the NGFB system. 
A summary of the major contributions from this study include:

- Characterization of current campus steam data at WVU and the data obtained are used in surface plant design

- Evaluation of the existing district heating system for the proposed new steam generation system

- Two design scenarios were investigated based on campus steam data and master campus district heating and cooling system drawings provided by WVU Facilities Management.

- Rigorous design of the surface plant equipment in Aspen EDR including plate heat exchangers and shell and tube heat exchangers for fuel preheater.

- Improvement of the two hybrid scenarios was further investigated to extract more heat from secondary fluid using heat pump in order to lower the LCOH at WVU.

- Surfaced plant capital costs are calculated in Aspen ACCE

- Determined the total surface plant costs (capital cost, utility cost, and O\&M costs) for the project

- The GEOPHIRES code written in Python was modified for the proposed hybrid system.

- The data obtained from surface plant design in Aspen simulators and the reservoir output parameters obtained from reservoir simulations provided the primary input fed into the modified GEOPHIRES in order to determine the LCOH for the proposed hybrid GDHC system.

- GEOPHIRES simulation results show that the two scenarios investigated require a capital investment of about 16.72 to $27.93 \$ \mathrm{M}$ for the vertical well configuration and a 21.21 to 34.95 \$M for the horizontal well configuration.

The overall conclusion from this study is that the proposed hybrid GDHC system for the WVU could provide a competitive, cost-effective energy to replace the existing MEA coal fired steambased system. However, the proposed hybrid GDHC system cannot compete economically with the NGFB system alone at current price of natural gas. However, further analysis of the future price of fuel showed that proposed hybrid system would be more economical compared to NGFB at a natural price of above $\$ 15.00 / 1000 \mathrm{ft}^{3}$. Furthermore, the proposed hybrid GDHC system has environmental benefits of reducing fossil fuel consumption at WVU campus. 


\subsection{Recommendations for the Future Work}

The possibility of conversion of the existing steam-based system to a hot water-based system needs to be assessed. The overall objective of this analysis should be to compare the hybrid geothermalnatural gas system proposed in this study with DDU system design that could provide hot water for campus heating and cooling. It has been projected that the conversion of existing steam-based heating and cooling system to a hot water system is not economical. In order to validate or reject this assumption, WVU steam data should be analyzed to evaluate the potential of converting the existing steam-based system to geothermal hot water system where geothermal supplies all the heating and cooling requirements for the WVU campus.

To achieve this objective, the following steps needs to be considered:

- Collection of background information for the conversion of current steam system to hot water system including WVU campus hot water demand or usage, central plant conditions and percentage of the total steam that can be converted to hot water

- Challenges of converting existing steam-based system to hot water system

- Some equipment replacements for the proposed hot water system design

- Centralized surface plant facility design with the appropriate temperature and pressure should be considered for the hot water system design.

- New distribution piping networks should be considered for the campus pipelines as higher hot water flow rates would be required to meet campus heating and cooling demand.

The hot water system components should include a heat exchanger, a heat pump system, new pipeline networks, circulatory and condensate pumps, tanks, and a separate boiler to provide steam requirements of some buildings equipment. The proposed hot water system should be independent of the existing DHC distribution system. For a giving hot water flow rate, the piping system should be modeled to optimize the diameter of the pipelines in order to minimize heat, temperature and pressure losses. Here, hot water at fixed temperature, pressure, and certain flow rate needs to be circulated through the campus loop by the circulatory pump. The overall design should have an efficient pumping system at certain intervals to circulate hot water through the campus loop system. Since geothermal well location is less than $5 \mathrm{~km}$, heat losses should be negligible, and temperature drop along the pipeline should be well below $5^{\circ} \mathrm{C}$. Again, as in hybrid system, Aspen 
simulators (Aspen Plus and HYSYS) should be used to simulate and evaluate the surface plant capital costs consisting of equipment and piping costs. The total capital cost for the hot water system should be estimated. Finally, the $\mathrm{LCOH}$ obtained from the proposed hot water system should be compared with the proposed hybrid GDHC system from this work. The feasibility of the proposed hot water and hybrid GDHC systems should be determined by comparing costs and benefits of the hot water system with existing MEA coal-fired steam-based system. 


\section{References}

[1] E. I. A. EIA, "Energy Information Administration. (2017). Annual Energy Review 2017. from www.eia.doe.gov.," 2017.

[2] P. Tans and R. Keeling, "Global Greenhouse Gas Reference Network: Trends in Atmospheric Carbon Dioxide," 2018.

[3] M. Ritchie, Hannah, Roser, "Renewables," Renewables, 2018.

[4] R. Hannah and M. Roser, " $\mathrm{CO}_{2}$ and other Greenhouse Gas Emissions," 2018. [Online]. Available: https://ourworldindata.org/co2-and-other-greenhouse-gas-emissions.

[5] J. Tester et al., "The Future of Geothermal Energy: An Assessment of The Energy Supply Potential Of Engineered Geothermal Systems (EGS) For the United States," Proceedings, Thirty-Second Work. Geotherm. Reserv. Eng., 2007.

[6] E. I. A. EIA, "Energy Information Administration. (2007a). Annual Energy Review 2006. from www.eia.doe.gov.," 2007.

[7] E. I. A. EIA, “Energy Information Administration. (2018). Annual Energy Review 2018. from www.eia.doe.gov.," 2018.

[8] P. Lienau, J. Lund, and G. Culver, "Geothermal direct use in the United States update: 1990-1994,” GHC Q. Bull., vol. 16 (No. 2), no. 2, p. 1, 1995.

[9] K. D. Rafferty, "Marketing the Klamath Falls Geothermal District Heating System," no. Geo-Heat Center for the D.O.E., 1993.

[10] J. Lund, P. Lienau, K. Rafferty, and G. Culver, "Reference Book on Geothermal Direct Use," Geo-Heat Center, Oregon Institiute Technol. Klamath Falls, OR, 1994.

[11] J. W. Lund and P. J. Lienau, "Geothermal district heating," Int. Geotherm. Days, p. p.18, 2009.

[12] P. Lienau and J. Lund, "Geothermal Direct-Use," Geo-Heat Cent. Oregon Inst. Technol., 1992.

[13] K. D. Rafferty, "New ways to produce geothermal power at lower temperatures. Power 
Engineering 117, 14-14.," Geo-Heat Center, Oregon Institiute Technol. Klamath Falls, OR, 1989.

[14] K. D. Rafferty, "A Century of Service: The Boise Warm Springs Water District System.," Geo-Heat Center, Oregon Institiute Technol. Klamath Falls, OR, 1992.

[15] K. D. Rafferty, "Direct Use : A Reality Check. GRC Bulletin(July/August).," 2003.

[16] D. B. Fox, D. Sutter, and J. W. Tester, "The thermal spectrum of low-temperature energy use in the United States," Energy Environ. Sci., vol. 4, no. 10, pp. 3731-3740, 2011.

[17] J. W. Tester, "Lessons learned from energy use in the U.S. †," 2011.

[18] T. Reinhardt, "New Ways to Produce Geothermal Power at Lower Temperatures.," Power Eng., vol. 117, no. 4, pp. 14-14, 2013.

[19] D. Blackwell et al., "SMU Geothermal Laboratory Heat Flow Map of the Conterminous United States.," 2011.

[20] Tester, "The Future of Geothermal Energy Impact of Enhanced Geothermal Systems (EGS) on the United States in the 21 st Century," 2006.

[21] T. E. Jordan et al., "Low-Temperature Geothermal Play Fairway Analysis for the Appalachian Basin,” no. Figure 1, pp. 1-11, 2016.

[22] K. F. Beckers and K. Mccabe, "Introducing Geophires V2 . 0 : Updated Geothermal Techno-Economic Simulation Tool," 43rd Work. Geotherm. Reserv. Eng., vol. 7, no. 1987, pp. 1-7, Dec. 2018.

[23] H. H. Thorsteinsson, "U . S . Geothermal District Heating : Barriers and Enablers. Master Thesis, Massachusetts Institute of Technology.," 2008.

[24] EGEC, "Developing geothermal district heating in europe," Eur. Geotherm. Energy Counc., p. 64, 2011.

[25] P. Dumas and L. Angelino, "GeoDH : Promote Geothermal District Heating Systems in Europe," Proc. World Geotherm. Congr., no. April, pp. 19-25, 2015.

[26] A. S. Loftsdottir and R. I. Thorarinsdottir, "Energy in Iceland. Reykjavik, Iceland: 
Ministries of Industries and Commerce," 2006.

[27] A. Richter, "United States - Geothermal Energy Market Report,” 2007.

[28] H. H. Thorsteinsson and J. W. Tester, "Barriers and Enablers to Geothermal District Heating System Development in the United States.," Energy Policy, vol. 38, no. 2, pp. $803-813,2010$.

[29] B. D. Green and R. G. Nix, "Geothermal - The Energy Under Our Feet (No. NREL/TP840-40665):," Natl. Renew. Energy Lab., 2006.

[30] D. M. Snyder, K. F. Beckers, and K. R. Young, "Update on Geothermal Direct-Use Installations in the United States," Proceedings, vol. 42, pp. 1-7, 2017.

[31] The World Bank, "Geothermal handbook: Planning and Financing Power Generation.," 2012.

[32] M. Z. Lukawski et al., "Journal of Petroleum Science and Engineering Cost analysis of oil , gas , and geothermal well drilling,” J. Pet. Sci. Eng., vol. 118, pp. 1-14, 2014.

[33] U. Friedrich, "Converting Steam-based District Heating Systems to Hot water,” 2007.

[34] Rafferty, "Geothermal Retrofit of Existing Space Heating Systems," OIT, GEO-Heat Cent. Klamath Falls, OR, 1986.

[35] J. W. Lund, "Examples of United States geothermal district heating systems," Geo-Heat Cent. Oregon Inst. Technol., vol. 17, 1999.

[36] G. H. J. Lund, B. Sanner, L. Rybach, R. Curtis, “Geothermal (Ground-Source) Heat Pumps a World Overview.pdf," no. January, pp. 1-10, 2004.

[37] R. G. Bloomquist, "A Review and Analysis of the Adequacy of the U.S. Legal, Institutional and Financial Framework for Geothermal Development Geothermics," vol. 15, no. 1 , pp. $87-132,1986$.

[38] K. Rafferty, "Fossil Fueled-Fired Peak Heating for Geothermal Greenhouses," Energy, no. December, pp. 1-4, 1996.

[39] L. J.W. and L. P.J, “Geothermal District Heating. Geothermal District Heating Schemes - 
Course Text Book, International Summer School, Skopje, Macedonia, pp. 33-1 to 33-37.," 1997.

[40] K. F. Beckers, M. Z. Lukawski, G. A. Aguirre, S. D. Hillson, and J. W. Tester, "Hybrid Low-Grade Geothermal-Biomass Systems for Direct-Use and Co-Generation: from Campus Demonstration to Nationwide Energy Player," Fortieth Work. Geotherm. Reserv. Eng., pp. 1-11, 2015.

[41] M. Z. Lukawski, K. Vilaetis, L. Gkogka, K. F. Beckers, B. J. Anderson, and J. W. Tester, "A Proposed Hybrid Geothermal-Natural Gas-Biomass Energy System for Cornell University. Technical and Economic Assessment of Retrofitting a Low-Temperature Geothermal District Heating System and Heat Cascading Solutions,” 2013.

[42] Rafferty and K. Rafferty, "Geothermal Retrofit of Existing Space Heating Systems," OIT, GEO-Heat Cent. Klamath Falls, OR, 1986.

[43] K. Rafferty, "Chapter 11 Heat Exchangers," in Geothermal Direct Use Engineering and Design Guidebook, 3rd ed., 1998, pp. 1-32.

[44] P. Lienau, "Geothermal Direct-Use Equipment Overview," Geo-Heat Cent. Oregon Inst. Technol., vol. 19, no. 1, 1998.

[45] K. F. Beckers and K. McCabe, "GEOPHIRES v2.0: updated geothermal techno-economic simulation tool," Geotherm. Energy, vol. 7, no. 1, p. 5, 2019.

[46] J. L. Hernandez-Galan and L. Alberto Plauchu, "Determination of fouling factors for shell-and-tube type heat exchangers exposed to los azufres geothermal fluids," Geothermics, vol. 18, no. 1-2, pp. 121-128, 1989.

[47] A. Garg, "Get the most from your fired heater," Chem. Eng., vol. 111, no. 3, pp. 60-64, 2004.

[48] A. Garg, "Optimize Fired Heater Operations to Save Money,” Hydrocarb. Process., vol. 76, no. 6, pp. 97-104, 1997.

[49] Q. Nasir, K. M. Sabil, and K. Nasrifar, "Measurement and Phase Behavior Modeling (Dew Point+Bubble Point) of Co2 Rich Gas Mixture," J. Appl. Sci., vol. 14, no. 10, pp. 
1061-1066, Oct. 2014.

[50] J. . Rafferty, "Piping," Geo-Heat Cent. Oregon Inst. Technol., no. March, pp. 241-259, 1998.

[51] K. Rafferty, "Geothermal District Piping - A Primer," Geo-Heat Center, Klamath Fall, OR., 1989.

[52] Y. Cengel and M. Boles, Thermodynamics: An Engineering Approach., 8th ed. McGraw Hill, 2014.

[53] A. Staffell, I., Brett, D., Brandon, N., and Hawkes, "A review of domestic heat pumps.," Energy Environ. Sci., vol. 5, no. 11, pp. 9291-9306, 2012.

[54] O. Bamigbetan, T. M. Eikevik, P. Nekså, M. Bantle, and C. Schlemminger, "The development of a hydrocarbon high temperature heat pump for waste heat recovery," Energy, vol. 173, pp. 1141-1153, Apr. 2019.

[55] Hendrick C. Van Ness Michael M. Abbott, "Thermodynamics," Kirk-Othmer Encycl. Chem. Technol. (Ed.)., 2000.

[56] M. B. B. Michael J. Moran, Howard N. Shapiro, Daisie D. Boettner, Fundamentals of Engineering Thermodynamics. Wiley, 2010.

[57] R. E. Peters, Max S., Timmerhaus, Klaus D., West, Plant Design and Economics for Chemical Engineers. McGraw- Hill Chemical Engineering Series, 2003.

[58] K. F. Beckers, M. Z. Lukawski, T. J. Reber, B. J. Anderson, M. C. Moore, and J. W. Tester, "Introducing Geophires V1.0: Software Package for Estimating Levelized Cost of Electricity and/or Heat From Enhanced Geothermal Systems," Proceedings, Thirty-Eighth Work. Geotherm. Reserv. Eng. Stanford Univ. Stanford, California, Febr. 11-13, 2013.

[59] K. F. Beckers, M. Z. Lukawski, B. J. Anderson, M. C. Moore, J. W. Tester, and J. W. Beckers, K. F., Lukawski, M. Z., Anderson, B. J., Moore, M. C., and Tester, "Levelized costs of electricity and direct-use heat from Enhanced Geothermal Systems," J. Renew. Sustain. Energy, vol. 6, no. 013141, pp. 1-15, 2014.

[60] R. W. Hardie, "BICYCLE II: A Computer Code for Calculating Levelized Life-Cycle 
Costs, LA-89089.," Los Alamos Natl. Lab. Los Alamos, New Mex. United States, 1981.

[61] G. P. Towler and R. K. Sinnott, Chemical engineering design: Principles, practice and economics of plant and process design, 2nd ed. Butterworth-Heinemann, 2012.

[62] R. Turton, joseph Shaeiwitz, D. Bhattachraryya, and W. Whiting, Analysis, Synthesis, and Design of Chemical Processes, 5th ed. Prentice Hall, 2018.

[63] K. F. Beckers and K. R. Young, "Performance, Cost , and Financial Parameters of Geothermal District Heating Systems for Market Penetration Modeling under Various Scenarios," pp. 1-11, 2017.

[64] J. Tester et al., "Integrating Geothermal Energy Use into Re-building American Infrastructure," World Geotherm. Congr. 2015, no. April, pp. 19-25, 2015.

[65] T. J. Reber, K. F. Beckers, and J. W. Tester, "The transformative potential of geothermal heating in the U.S. energy market: A regional study of New York and Pennsylvania," 2014.

[66] M. Nandanwar, "Numerical Modeling and Simulations for Techno-economic Assessment of Non-conventional Energy Systems,” West Virginia University, 2016. 